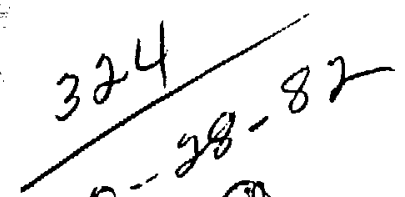

$10^{-1}$

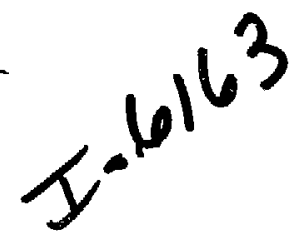

\title{
Laboratory Strudies of
}

Radionuclide Transport in

Fractured Climax Granite

\author{
Rebecca Failor \\ Dana Isherwood \\ Ellen Raber \\ Tjalle Vandergraaf
}

MASTEP

June 1982

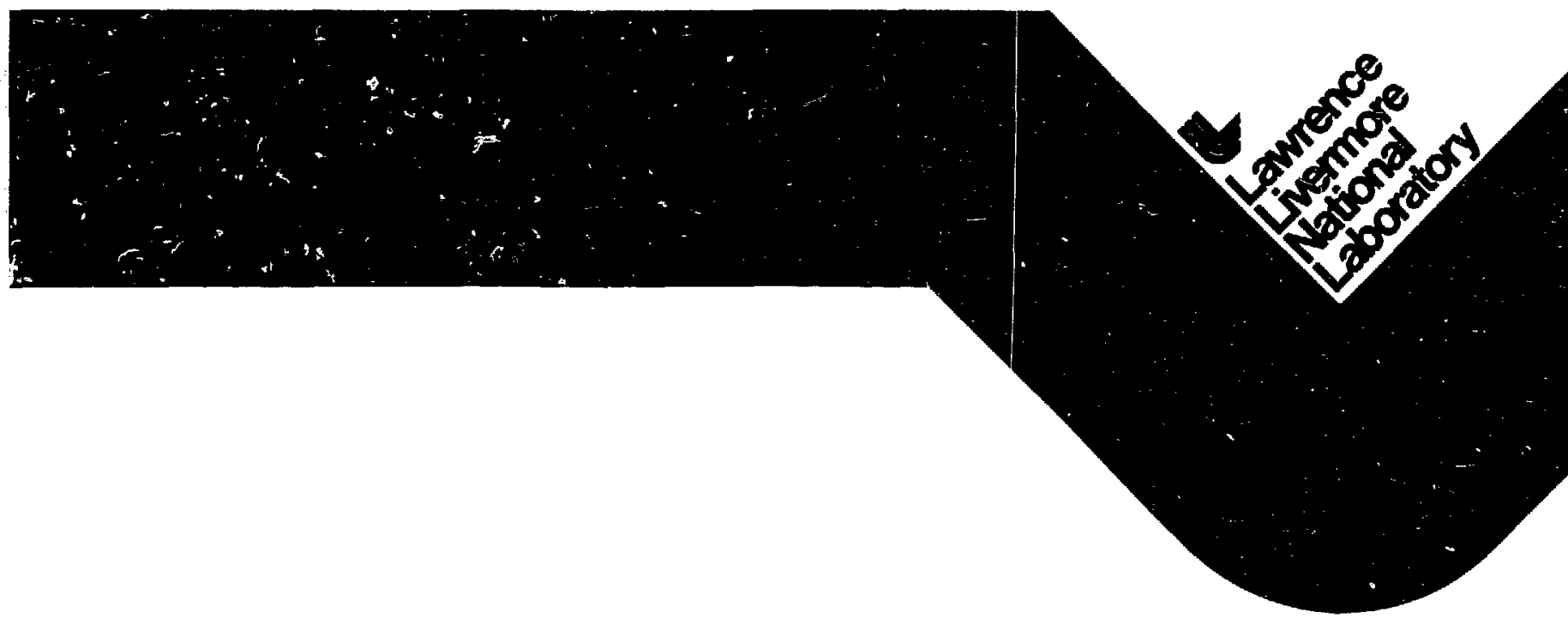


UCRL- -53308

DE83 001709

\section{Laboratory Studies of Radionuclide Transport in Fractured Climax Granite}

Rebecca Failor

Dana Isherwond

Ellen Fiaker

Tjalle Vandergraaf*

Manuscript date: June, 1982

"Whiteshell Nuclear Research Establishment, Pinawa, Manitoba, Canada 
Abstract

Introduction

Experimental Methods

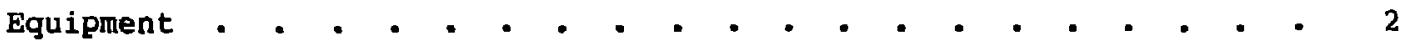

Core Preparation

Run Procedures

$\mathrm{\beta}^{-}$Analysis of Conservative Tracers

Physical Characteristics of the cores

Chemical Characteristics of Transport Solutions . - . . . . - . 15

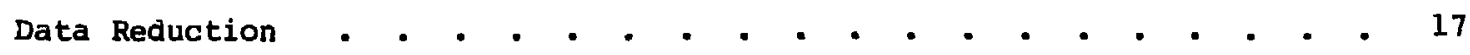

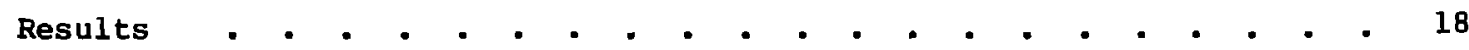

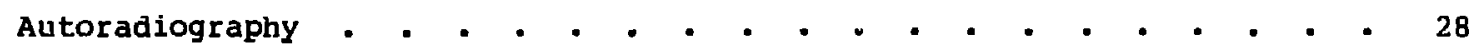

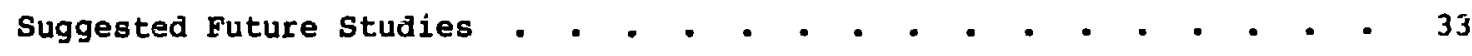

In Brief . • • • • • • • • • • • • • • • • • • • • 34

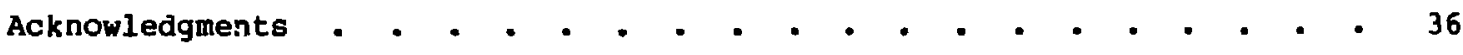

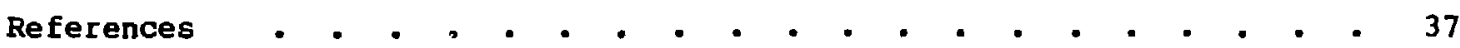

Appendix A: Equipment and Procedures _. . . . . . . . . . . . 41

Appendix B: Computer Program for Data Analysis . . . . . . . . 45 


\section{ABSTRACT}

This report documents our laboratory studies of radionuclide transport in fractured granite cores. To simulate natural conditions, our laboratory studies used naturally fractured cores and natural ground water from the Climax Granite Stock at the Nevada Test Site. For comparison, additional tests used artificially fractured granite cores or distilled water.

Relative to the flow of tritiated water, ${ }^{85} \mathrm{Sr}$ and ${ }^{95 \mathrm{~m}_{\mathrm{T}}}$ showed little or no retardation, whereas ${ }^{137}$ Cs was retarded. After the transport runs the cores retained varying amounts of the injected radionuclides along the fracture. Autoradiography revealed some correlation between sorption and the fracture fill material. Strontium and cesium retention increased when the change was made from natural ground water to distilled water. Artificial fractures retained less ${ }^{137} \mathrm{Cs}$ than most natural fractures. Estimated fracture apertures from 18 to $60 \mu \mathrm{m}$ and hydraulic conductivities from 1.7 to $26 \times 10^{-3} \mathrm{~m} / \mathrm{s}$ were calculated from the core measurements.

INTRODUCTION

Transport of radionuclides in ground water through crystali ine rock will take place primarily along fractured surfaces. Retardation and sorption characteristics of the fracture surfaces differ from the characteristics of the crushed bulk rock samples described in previous studies (Coles et al., 1980; Los Alamos National Laboratory, 1980; MacLean et al., 1978). In the past, theoretical models describing radionuclide transport through fractured rock relied heavily on experimental results from static sorption or column tests on crushed rock for empirical values and model validation. Little laboratory or field data exist for radionuclide transport along fractures.

In our experiments, transport solutions spiked with radionuclides were pumped through fractured granite cores to simulate natural conditions. Our laboratory experiments were designed to study the effects of fracture fill material and transport solution on radionuclide transport and sorption by 
using natural ground water and distilled water in both natural and artificial fractures. The core sorption apparatus and techniques, initially developed by Weed at LLNL (Weed et al., 198la,b), were designed to simulate natural flow rates and lithostatic pressures. The granite for our experiments was obtained from the climax stock at the Nevada Test Site. Our interest in nuclear waste disposal prompted our choice of the radionuclides ${ }^{3} \mathrm{H},{ }^{85} \mathrm{Sr},{ }^{95} \mathrm{~m}_{\mathrm{Tc}}$, and 137 Cs for this study.

This report discusses the equipment used, the preparation of the core, the experimental procedure, the data reduction, and the experimental results from eleven cores. The results include estimates of the average fracture aperture values, retardation values of ${ }^{85} \mathrm{Sr},{ }^{95 m} \mathrm{Tc}$, and ${ }^{137} \mathrm{Cs}$ relative to ${ }^{3} \mathrm{H}$, and the percentage of each radionuclide retained in the core after each run.

The core sorption study is a logical step in determining the scaling factor from laboratory to field studies. We need field data to determine whether laboratory studies accurately reflect in situ conditions. The studies described in this report were originally part of the Waste Rock Interaction (WRIT) Program administered by Pacific Northwest Laboratory (PNL). They were later included in the geochemical support studies for the Field Radionuclide Migration in climax Granite Project funded by the office of Nuclear Waste Isolation (ONWI) as described in Isherwood et al. (1982a). The objective of this project was to provide field-measured retardation factors for comparison with the laboratory measured values. Both the field and laboratory studies were designed to provide input to mass transport models to improve our ability to make dependable pretest predictions of radionuclide migration in fractured rock. The planned core sorption studies were not completed due to project cancellation; however, the results obtained provide information useful for understanding the processes influencing radionuclide migration.

\section{EXPERIMENTAL METHODS}

EQUIPMENT

Weed et al. $(1981 a, b)$ developed the core sorftion apparatus and techniques to simulate the flow of radionuclides through porous rock. Our 
program modified the equipment and procedure to study fracture flow in crystalline rock (see Appendix A). The apparatus approximates naturally occurring conditions by applying confining pressure to simulate the rock's overburden pressure. The transport solution passes through the core at a slow (approximately $0.002 \mathrm{ml} / \mathrm{min}$ ) flow rate.

A schematic of the experimental satup (Fig. 1) shows the flow path as the solution flows from the reservoir, is pumped through the spike loop containing the radionuclide mixture, through the tubing and the core and into the sample tubes in the fraction collector. The volume of the tubing and the end fitting is called the system dead volume. A more complete description of the experimental concept, equipment, and procedure is found in previous reports (weed et al., 1981a; Coles et al., 1980).

Appendix A details the equipment changes we made to convert from a study of porous rock cores (Weed et al., 1981a) to fractured rock cores. Briefly, we:

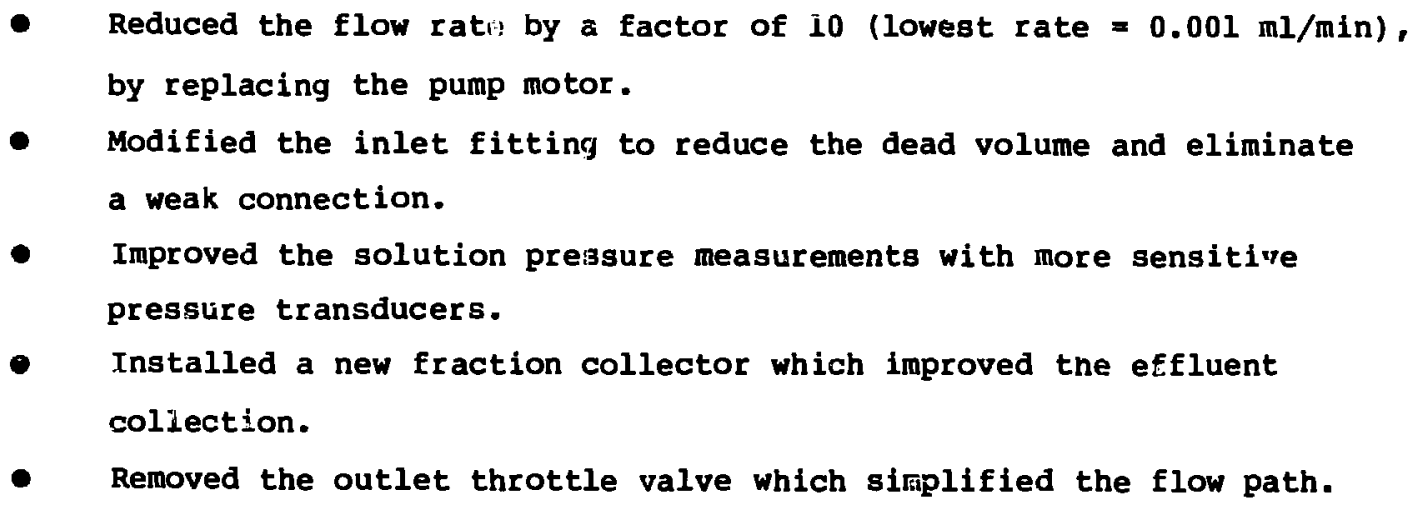

CORE PREPARATION

The overall procedure for the fractured core sorption runs differed very little from the porous core run's (Weed et al., 1981a). The major difference was in the core preparation.

The Pileơriver Drift tunnels into the Clinax stock granite $400 \mathrm{~m}$ below the surface. NX (76 mm) boreholes were drilled horizontally into the face of the tunnel wall to intersect sets of high angle fractures. These holes were later used to study the hydrologic flow characteristics of the Climax Stock fractures (Isherwood et al., 1982a). Approximately $54 \mathrm{~m}$ of core (48 mm in diameter) containing a variety of natural fractures are now available. Before 


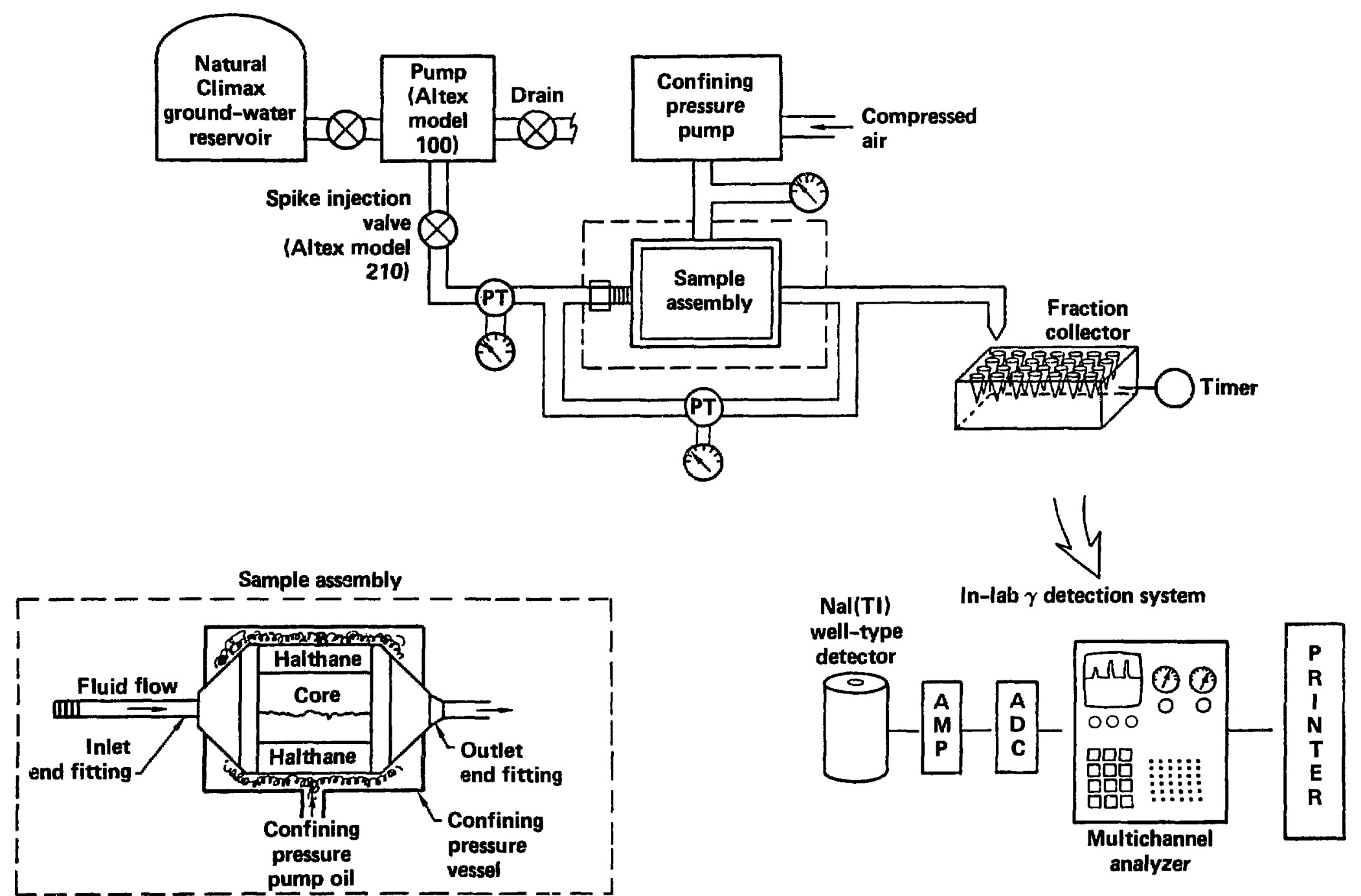

Figure 1. Schematic of core sorption experimental setup. 
selecting the core sections, a visual check of the cores was made to differentiate between natural fractures and mechanical breaks.

The method of preparing the 25- $\mathrm{mm}$ cores for use in the radionuclide transport runs is illustrated in Fig. 2 (Steps 1-8). Often the NX cores broke apart along the natural fractures (Step 1) during the drilling process. In these cases the core was carefully reassembled and kept intact with 12-mm

1.
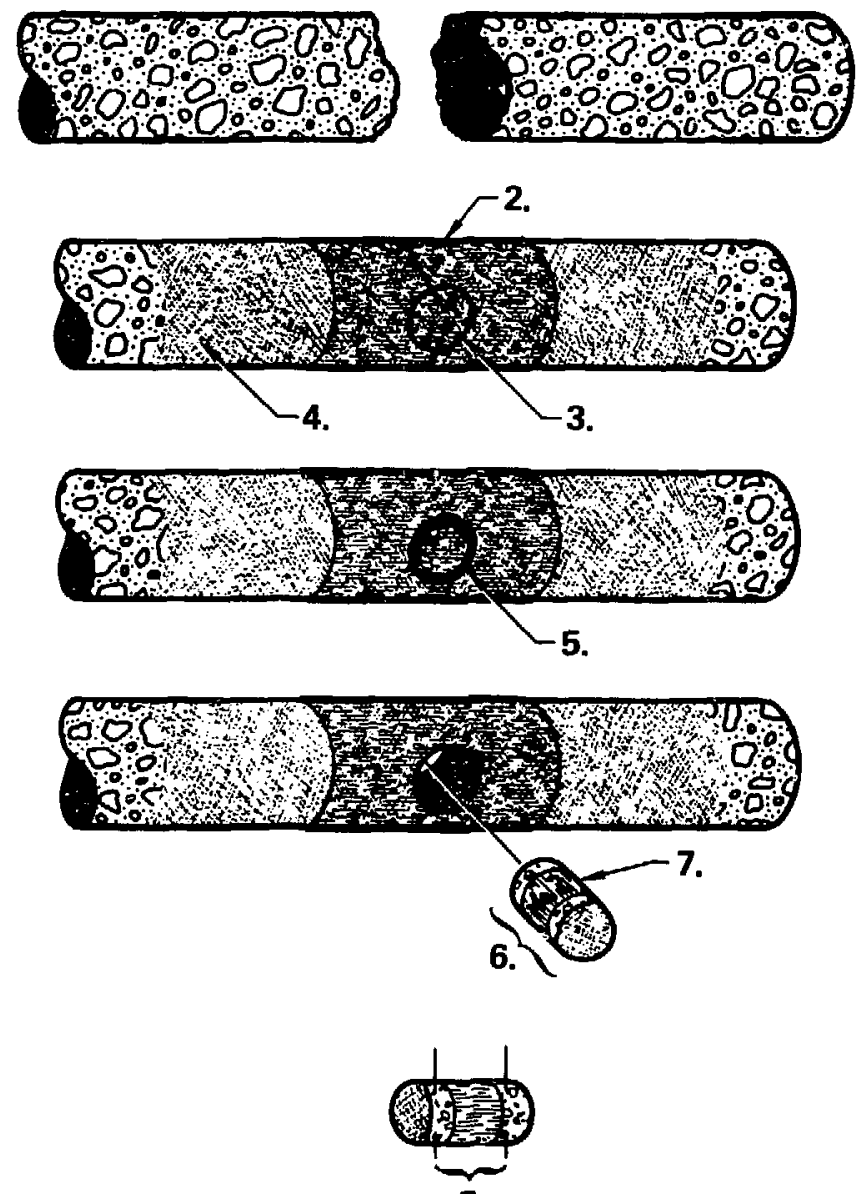

8.

Step 1: The fracture is carefully reassembled.

Step 2: Duct tape holds the fracture intact.

Step 3: The angle of drilling is marked on the tape.

Step 4: Fiberglass cloth is wrapped around the core and saturated with epoxy.

Step 5: Core is drilled with a diamond bit and drill press.

Step 6: A 1- $\times 2$ 1/2-in. core with epoxy caps results from drilling.

Step 7: Duct tape holds and marks the core.

Step 8: The core is sawed to the desired length.

Figure 2. Preparation of $25 \mathrm{~mm}$ cores from NX cores. 
heavy duct tape (Step 2). Intact undisturbed fractures were also taped to avoid epoxy penetration of the fracture. The tape was marked establishing the best drilling angle such that the 25-mm core contained a fracture running along the entire length of the core (Step 3).

The NX core was wrapped twice in fiberglass cloth, saturated with Shell 828 epoxy, and allowed to dry (Step 4). Using a water-lubricated diamond bit and press, a 25-mm core was drilled from the NX core (Step 5 ). The resuiting $25-\mathrm{mm}$ core was $48 \mathrm{~mm}$ in length. Epoxy caps at either end held the core together (Step 6). The sides of the core were wrapped in duct tape (Step 7), and the core was cut to the desired length with a Buehler ISO-MET saw with a diamond blade (Step 8 ). The resulting 25-mm-ciiameter core contuined a natural fracture running the full length of the core.

Studying natural vs artificial fractures indicated the effects of fracture fill material on the sorption of the radionuclides. To obtain

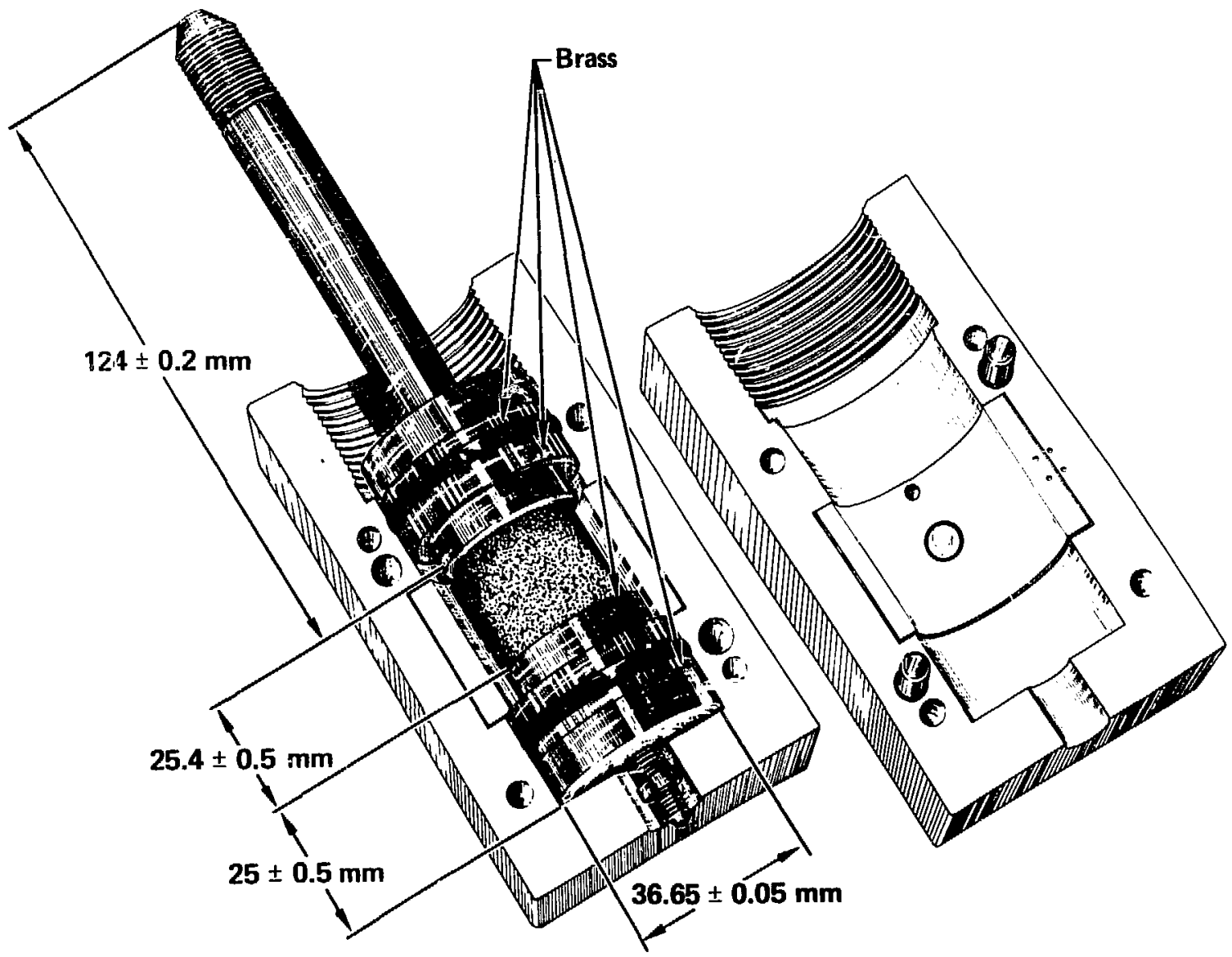

Figure 3. Teflon muld; sample and end fittings before injection of Halthane 73-18. 
artificially fractured cores a 25-mn-diameter core was drilled from NX core containing no fractures (Steps $1-8$ ). The edges of the $25-\mathrm{mm}$ core were chiseled until the core fractured along an induced cleavage plane. These cores were treated in the same way as naturally fractured cores.

The 25-mm cores were prepared for the radionuclide transport run by jacketing them in the polyurethane adhesive Halthane 73-18 'Hammon and Alihouse, 1977). The core was placed into the stainless steel end fittings and the edges of the fracture and interface between the core and end fittings were sealed with very viscous Halthane and left to cure overnight. This step was a precaution taken to avoid filling the fracture with the unpolymerized Halthane mixture when the jacket was molded around the core. The core and end fittings were then put into the Teflon jacketing mold (Fig. 3). The prepolymer and curing agent components of the Halthane were mixed, degassea,, and injected into the bottom of the mold. After filling the mold with Halthane 73-18, it was left to cure overnight. The jacketed sample was carefully removed from the mold (Fig. 4) (Weed et al., 1981a).

It was very important that the Halthane jacket prevent the transport solution from flowing between the core edges and the jacket. To verify the seal between the core and the jacket, Rhodamine B, a dye which permanently
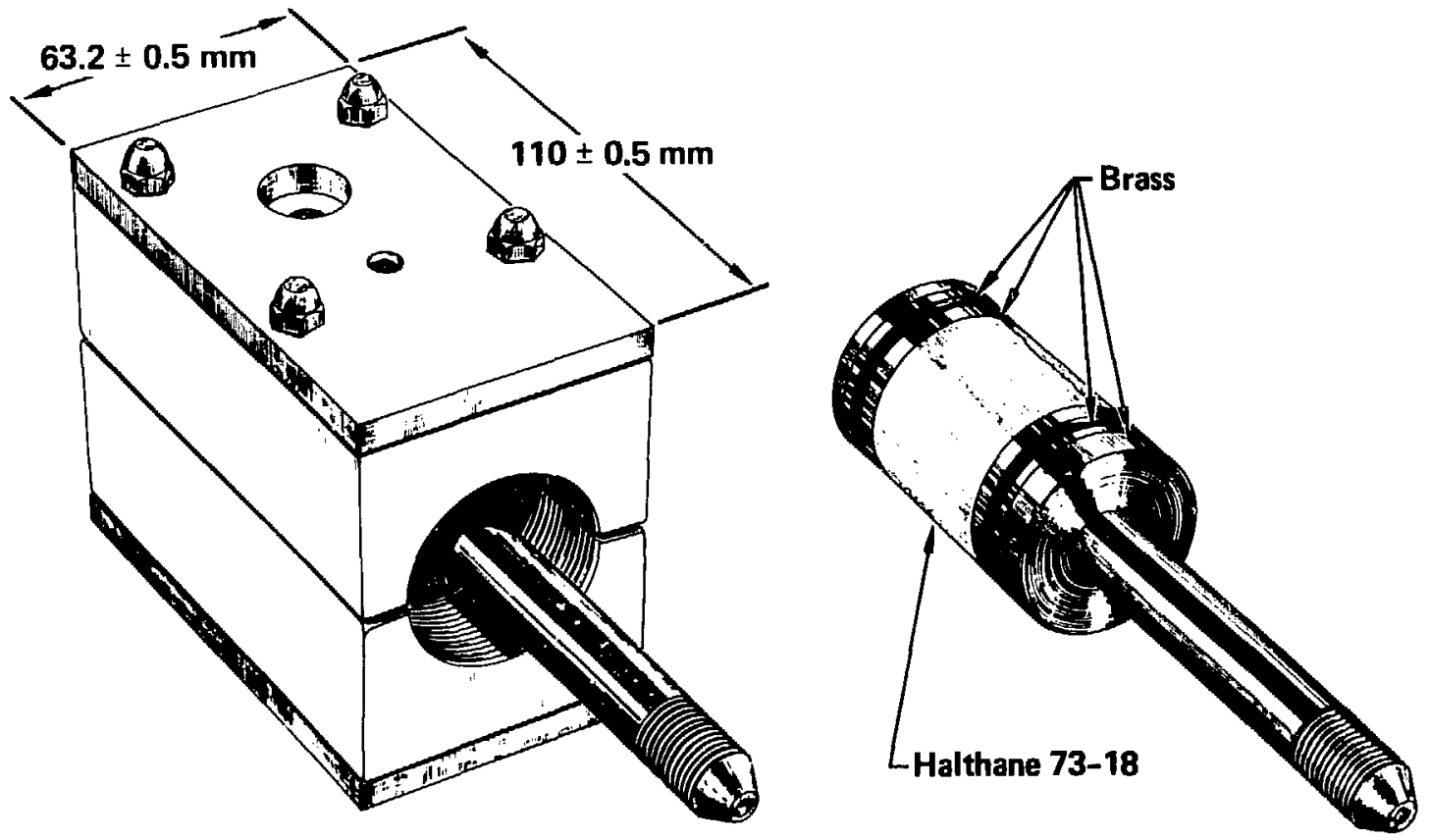

Figure 4. Assembled mold, sample and end fittings jacketed in Halthane 73-18. 
stains Halthane, was pumped through two cores to check the flow paths. Dye was not found on the jacket or core except at the ends and where the fracture touches the jacket.

RUN PROCEDURES

After the core was jacketed, the sample assembly was placed into the experimental setup (Fig. 1). The radionuclide spike was loaded into the spike loop and held until the time of injection. While the transport solution was being run through the core, the confining pressure was incrementally increased until the fluid inlet and differential pressures plateaued. This confining pressure was between 10 and $22 \mathrm{MPa}$ for all the cores studied. Higher confining pressures were avoided since asperities in the fracture surface could be crushed exposing fresh surface to the solution and possibly blocking the fracture flow. The confining pressure was held at the maximum value reached and not reduced throughout the run to avoid possible hysteresis effects.

Confining, inlet and differential pressures, pump flow settings, and sampling intervals were recorded throughout the run. After transport solution had been pumped through the fracture for at least $24 \mathrm{~h}$ the spike was injected. After the spike passed through the core and the gamma $(\gamma)$ activity levels of the effluent dropped to a few percent above background, the $r$ un was ended.

After the run, the core was potted in epoxy and sliced normal to the fracture with a diamond saw. An organic lubricating solution was used to avoid washing away any sorbed activity. To determine the amount of the radionuclides retained in the core the slices (approximately 13) were $\gamma$-counted.

\section{$\mathrm{B}^{-}$analysis of conservative tracers}

Tritiated water (HTO) serves as a conservative (nonretarded) tracer for determination of the retardation factors for ${ }^{85} \mathrm{Sr},{ }^{95 \mathrm{~m}_{\mathrm{TC}}}$, and ${ }^{137} \mathrm{Cs}$. To test the validity of tritiated water as a nonretarded tracer we included ${ }^{36} \mathrm{Cl}$ in some early runs as a second conservative tracer. Chloride ion is often used as a matker ion for water movement. 
The radionuclide spikes which contained ${ }^{36} \mathrm{Cl}$ (for cores $7,6 \mathrm{~A}$, and 6B) also contained ${ }^{95} \mathrm{~m}$ TC. Technetium-95m has a $\beta^{+}$emission which interferes with quantitative detection of ${ }^{3} \mathrm{H}$. Then ${ }^{95 \mathrm{~m}}$ Tc was present, the samples for ${ }^{3} \mathrm{H}$ analysis were vacuum distilled prior to liquid scintiliation coun ing. The distillation process did not, however, quantitatively recover the ${ }^{36} \mathrm{Cl}$ from the sample; hence, no data will be presented based on the 36

$\mathrm{Cl}$ analyses for cores $7,6 \mathrm{~A}$, and $6 \mathrm{~B}$.

We verified the conservative nature of tritium in our experiments in core 8 where we injected a spike containing only ${ }^{3} \mathrm{H}$ and ${ }^{36} \mathrm{Cl}$ in natural ground water. Since ${ }^{95 m_{T C}}$ was not present in the spike, vacuum distillation was unnecessary and the $\mathrm{B}^{-}$analysis for ${ }^{3} \mathrm{H}$ and ${ }^{36} \mathrm{Cl}$ used conventional liquid scintillation counting methods. Figure 5 displays the elution profiles from this run. The ${ }^{3} \mathrm{H}$ and ${ }^{36} \mathrm{CI}$ plots coincide, supporting our use of ${ }^{3} \mathrm{H}$

Fractured granite core 8 sorption run with ${ }^{3} \mathrm{H}$ and ${ }^{36} \mathrm{Cl}$ only

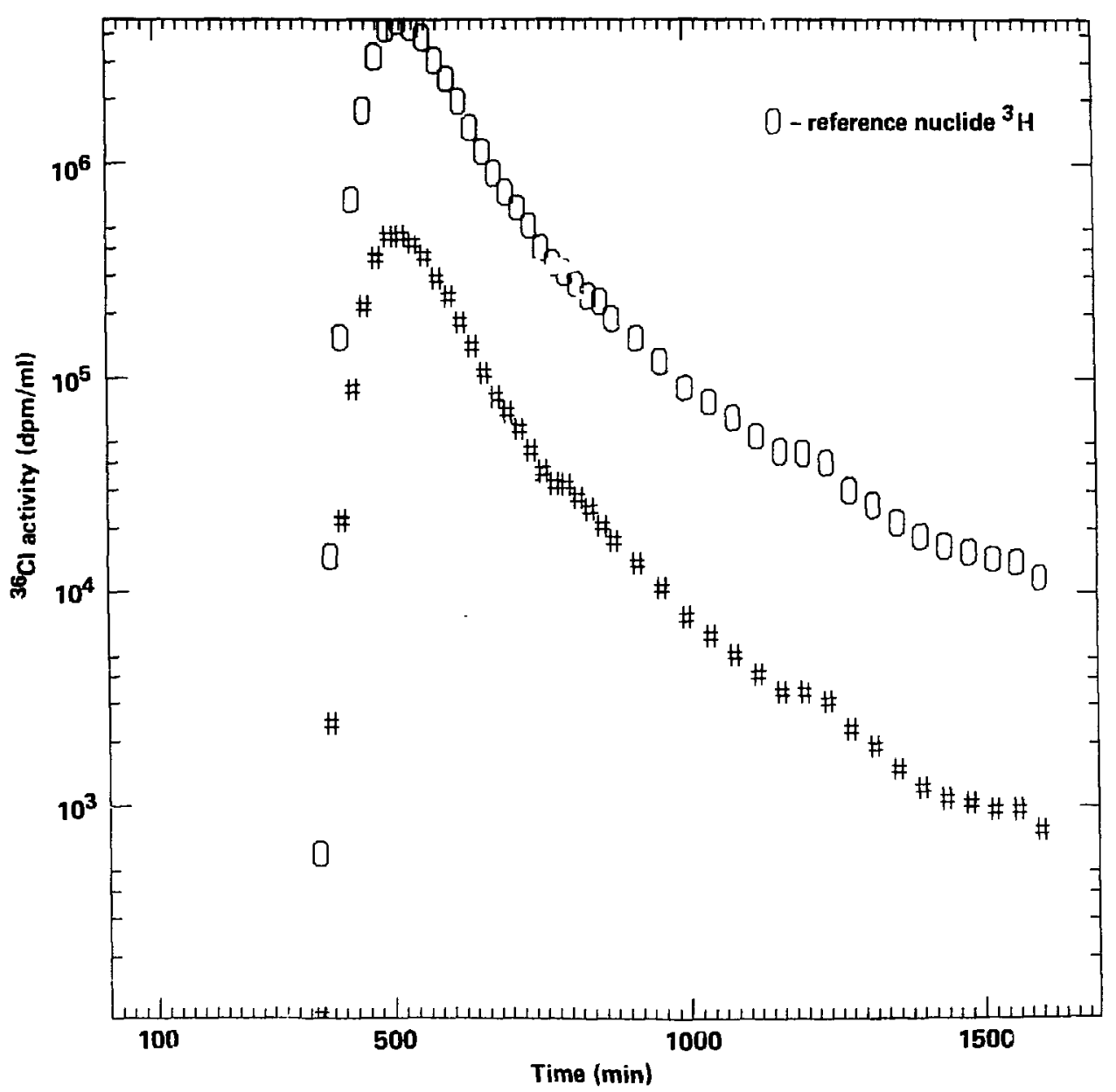

Figure $5 .{ }^{3} \mathrm{H}$ and ${ }^{36} \mathrm{Cl}$ overlap plot. 
as the reference radionuclide. This does not prove that HTO is not retarded relative to the water flow in some situations. However, it did serve as a useful check on the HTO behavior in our experiment with respect to another accepted conservative tracer, ${ }^{36} \mathrm{Cl}$.

\section{PHYSICAL CHARACTERISTICS OF THE CORES}

As previously stated we incrementally increased the confining pressure on the cores monitoring the differential and inlet pressures. Table 1 and Fig. 6 present the pressure data for an artificially fractured core (core 9). The differential fluid pressure remained below 1 psi with confining pressures of 10-21 MPa. The hydraulic conductivities for this $0.025-\mathrm{m}$ core follow the size effect trends seen by Witherspoon et al. (1979). For small cores, such as ours, the laboratory fracture permeability may be lower than the actual field value. This must be considered if the fracture permeability is used in any flow models.

Table 1. Calculzted aperture and conductivity at various confining pressures on an artiricial fracture in a $0.025-m$ granite core.

\begin{tabular}{clccc}
\hline $\begin{array}{c}\mathrm{P}_{\mathrm{C}}^{\mathrm{a}} \\
(\mathrm{MPa})\end{array}$ & $\begin{array}{c}\Delta \mathrm{h}^{\mathrm{b}} \\
(\mathrm{psi})\end{array}$ & $\begin{array}{c}\Delta \mathrm{h}^{\mathrm{b}} \\
\left(\mathrm{cm}, \mathrm{H}_{2} \mathrm{O}\right)\end{array}$ & $\begin{array}{c}\text { Fracture } \\
(\mathrm{m} / \mathrm{s})\end{array}$ & $\begin{array}{c}\mathrm{K}{ }^{\mathrm{C}} \\
(j \mathrm{~m})\end{array}$ \\
\hline 10 & 0.096 & 6.8 & $4.78 \times 10^{-4}$ & 25.6 \\
13 & 0.17 & 12.3 & $3.24 \times 10^{-4}$ & 21.0 \\
16 & 0.33 & 23.4 & $2.10 \times 10^{-4}$ & 17.0 \\
18 & 0.47 & 33.3 & $1.67 \times 10^{-4}$ & 15.1 \\
21 & 0.64 & 45.4 & $1.36 \times 10^{-4}$ & 13.6 \\
\hline
\end{tabular}

a $P_{C}=$ confining pressure.

b $\Delta \mathrm{h}=$ inlet pressure - outlet pressure (converted from psi to cm using $1 \mathrm{psi}=70.9 \mathrm{~cm} \mathrm{H}_{2} \mathrm{O}$ ).

c Conductivity $\left(K_{f}\right)$ and fracture aperture were calculated using Egs. (2) and (4) from wither spoon et al., 1979. 


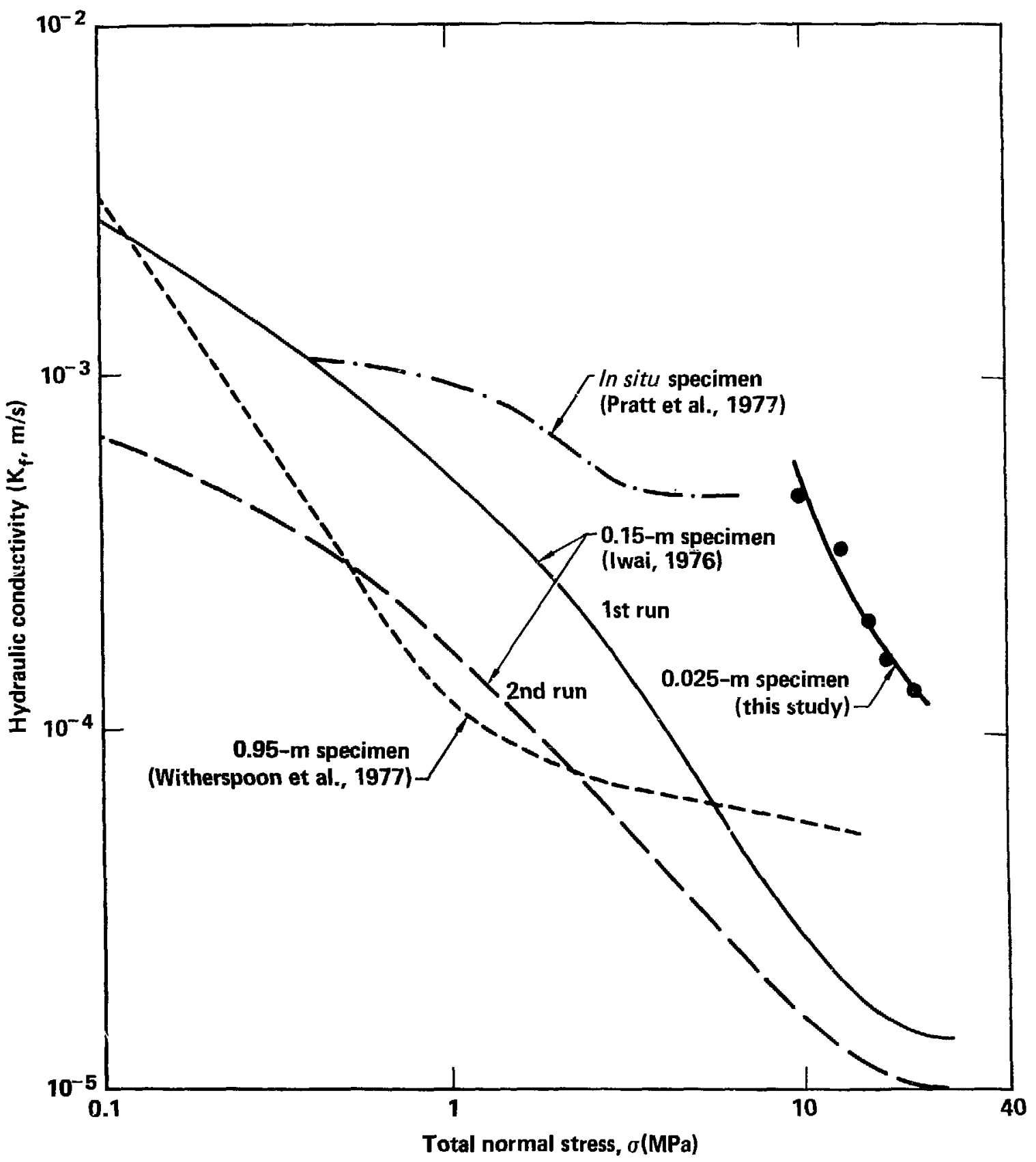

Figure 6. Variation of hydraulic conductivity in a fracture with increasing stress for four different size rock samples (results for $0.15-\mathrm{m}$ and $0.95-\mathrm{m}$ specimens are with radial divergent flow; results for in situ specimen and 0.025-m rock core are with linear flow). [Original from witherspoon et al., 1979$. 
Table 2 lists some of the run conditions for the eleven fractured granite cores. Table 3 gives the hydraulic conductivities and fracture apertures calculated from the gressure values in Table 2. Fill materials sealed the natural fractures in cores $8,21,22,23$, and 25 making them impervious to fluid flow. We stressed these cores along the natural fractures causing them to refracture. A fairly steady increase in the differential pressure in cores

Table 2. Pressures and flow rates for eleven fractured granite cores.

\begin{tabular}{|c|c|c|c|c|}
\hline $\begin{array}{c}\text { Core } \\
\text { No. }\end{array}$ & $\begin{array}{c}\text { Fracture } \\
\text { type }\end{array}$ & $\begin{array}{l}\text { Solution } \\
\text { flow rate } \\
\text { (ml/min) }\end{array}$ & $\begin{array}{l}\text { Solution } \\
\text { differential } \\
\text { pressure } \\
\text { (psid) }\end{array}$ & $\begin{array}{l}\text { Confining } \\
\text { pressure } \\
\text { (MPa) }\end{array}$ \\
\hline 5 & Natural & $0.046 \pm 0.004$ & $0.014 \pm 0.002$ & $11.0 \pm 0.2$ \\
\hline $6 \AA$ & Natural & $.0019 \pm .0003$ & $.02 \pm .01$ & $10.0 \pm .5$ \\
\hline $6 \mathrm{~B}$ & Natural & $.0020 \pm .0002$ & $.010 \pm .008$ & $11.0 \pm .5$ \\
\hline 7 & Natural & $.021 \pm .003$ & $.01 \pm .01$ & $22.0 \pm .5$ \\
\hline 8 & $\begin{array}{l}\text { Natural } \\
\text { Refractured }\end{array}$ & $.0020 \pm .0005$ & $.00024^{\mathrm{C}}$ & $9.0 \pm .6$ \\
\hline 21 & $\begin{array}{l}\text { Natural } \\
\text { Refractured }\end{array}$ & $.0015 \pm .0010$ & $.0006^{\mathrm{C}}$ & $12.0^{\mathrm{a}}$ \\
\hline 22 & $\begin{array}{l}\text { Natural } \\
\text { Refractured }\end{array}$ & $.0021 \pm .0003$ & $.0003^{c}$ & $14.0 \pm .3$ \\
\hline 23 & $\begin{array}{l}\text { Natural } \\
\text { Refractured }\end{array}$ & $.0020 \pm .0004$ & $.00130 \pm .00015$ & $12.0 \pm .7$ \\
\hline 25 & $\begin{array}{l}\text { Natural } \\
\text { Refractured }\end{array}$ & $\begin{array}{l}.002 \pm .0003^{b} \\
.01 \pm .002^{b}\end{array}$ & $.00150 \pm .00015$ & $13.0 \pm .4$ \\
\hline 9 & Artificial & $.0021 \pm .0007$ & $.28 \pm .03$ & $15.0 \pm .4$ \\
\hline 10 & Artificial & $0.0016 \pm 0.0009$ & $0.004 \pm 0.001$ & $15.0 \pm 0.7$ \\
\hline
\end{tabular}

a Due to a drop in laboratory temperature $P_{C}$ decreased to $5.45 \mathrm{MPa}$ for a short time.

b Flow rate was increased at the end of the run. The higher flow rate $(0.01 \mathrm{ml} / \mathrm{min})$ is used in the aperture calculations.

C Because particles apparently blocked the outlet giving an artificially high differential pressure, lowest measured values are listed. 
Táble 3. Hydraulic conductivity and aperture values for eleven fractured granitie cores.

\begin{tabular}{|c|c|c|c|c|c|}
\hline $\begin{array}{l}\text { Cor e } \\
\text { No. }\end{array}$ & $\begin{array}{c}\text { Flow rate, } \\
Q \\
(\mathrm{ml} / \mathrm{s}) \\
\times 10-5\end{array}$ & $\begin{array}{l}\text { Confining } \\
\text { pressure } \\
\mathrm{P}_{C} \\
\text { (MPa) }\end{array}$ & $\begin{array}{c}\text { Differential } \\
\text { pressure } \\
\Delta \mathrm{h} \\
\left(\mathrm{cm}, \mathrm{H}_{2} \mathrm{O}\right)\end{array}$ & $\begin{array}{l}\text { Hydraulic } \\
\text { conductivity } \\
\mathrm{K}_{\mathrm{f}} \\
(\mathrm{m} / \mathrm{s}) \\
\times 10^{-3}\end{array}$ & $\begin{array}{c}\text { Fracture } \\
\text { aperture } \\
(2 \mathrm{~b}) \\
(\mu \mathrm{m})\end{array}$ \\
\hline 5 & $77 . \pm 7$ & $11.0 \pm 0.2$ & $0.99 \pm 0.15$ & $16 \pm 3$ & $47 \pm 4$ \\
\hline $6 \mathrm{~A}$ & $3.2 \pm 0.5$ & $10.0 \pm .5$ & $1.4 \pm .07$ & $1.7 \pm 0.9$ & $15 \pm 4$ \\
\hline $6 \mathrm{~B}$ & $3.33 \pm 0.03$ & $11.0 \pm .5$ & $0.7 \pm 0.6$ & $2.6 \pm 1$ & $19 \pm 4$ \\
\hline 7 & $35.0 \pm 0.5$ & $22.0 \pm .5$ & $0.7 \pm 0.7$ & $12 \pm 6$ & $40 \pm 10$ \\
\hline 8 & $3.33 \pm 0.08$ & $9.0 \pm .6$ & $0.03^{a}$ & $\leq 21$ & $\leq 53^{a}$ \\
\hline 21 & $2.5 \pm 1.7$ & 12.0 & $0.04^{a}$ & $\leq 14$ & $\leq 44^{a}$ \\
\hline 22 & $3.5 \pm 0.5$ & $14.0 \pm .3$ & $0.024^{a}$ & $\leq 25$ & $\leq 58^{a}$ \\
\hline 23 & $3.33 \pm 0.07$ & $12.0 \pm .7$ & $0.09 \pm .01$ & $10.6 \pm 1$ & $38 \pm 2$ \\
\hline 25 & $3.5 \pm 0.5$ & $13.0 \pm .4$ & $0.11 \pm .01$ & $26.2 \pm 1$ & $60 \pm 3$ \\
\hline 9 & $3.5 \pm 1.2$ & $15.0 \pm .7$ & $0.28 \pm .07$ & $2.5 \pm 0.5$ & $1 c \pm 1$ \\
\hline 10 & $2.7 \pm 1.5$ & $15.0 \pm 0.7$ & $0.28 \pm 0.07$ & $4.2 \pm 0.7$ & $24 \pm 4$ \\
\hline
\end{tabular}

a Because particles apparently blocked the outlet giving an artificially high differential pressure, aperature values are upper linits only.

8, 21, and 22 led us to believe particles had broken loose during the refracturing and were moving to block the solution outlet, thereby increasing the differential pressure. Since the aperture is inversely proportional to the differential pressure, the apertures reported for cores 8,21 , and 22 are upper estimates.

The granite cores originated from boreholes in the Piledriver Drift of the climax stock at the Nevada Test Site. The Climax stock is composed of two major phases, an equigranular biotite granodiorite and a porphyritic biotite guartz monzonite. Our cores originated in the quartz monzonite containing large potassium feldspar phenocrysts (Conno11y, 1981). The report of J. A. Connolly contains a detailed description of the bulk minerals and alceration products found in the climax granite.

In the eleven core sorption experiments we used nine naturally fractured and two artificially fractured granite cores. Using x-ray diffraction 
Table 4. Fracture fill material.

\begin{tabular}{|c|c|c|c|c|c|}
\hline $\begin{array}{l}\text { Core } \\
\text { No. }\end{array}$ & $\begin{array}{l}\text { Borehole No., } \\
\text { depth (m) }\end{array}$ & $\begin{array}{l}\text { x-ray diffraction } \\
\text { identification }\end{array}$ & $\begin{array}{l}\text { Visual and } \\
\text { chemical } \\
\text { identification }\end{array}$ & $\begin{array}{c}\text { Average } \\
\text { fracture } \\
\text { fill thickness } \\
\text { (min) }\end{array}$ & Notes \\
\hline \multicolumn{6}{|c|}{ Natural, open Iractures } \\
\hline 5 & TT4, 5.9 & $\begin{array}{l}\text { X-ray diffraction } \\
\text { data not available }\end{array}$ & $\begin{array}{l}\text { Calcite confirmed } \\
\text { with } \mathrm{BCl}\end{array}$ & 1 & \\
\hline $\begin{array}{l}6 A, \\
6 B\end{array}$ & TT4, 3.4 & Quartz and calcite & $\begin{array}{l}\text { Calcite confirmed } \\
\text { with HCl }\end{array}$ & 0.1 to 0.5 & $\begin{array}{l}\text { Both cores are from } \\
\text { the same fracture }\end{array}$ \\
\hline 7 & $\mathrm{TT} 3,4.6$ & $\begin{array}{l}\text { Predominately calcite } \\
\text { guartz present }\end{array}$ & $\begin{array}{l}\text { Calcite confirmed } \\
\text { with HCl }\end{array}$ & 1 & \\
\hline \multicolumn{6}{|c|}{ Natural, intact fractures } \\
\hline 8 & TT3, 2.4 & $\begin{array}{l}\text { Predominately calcite } \\
\text { quartz present }\end{array}$ & $\begin{array}{l}\text { Calcite confirmed } \\
\text { with HCl }\end{array}$ & 1 & $\begin{array}{l}\text { Intact cores were } \\
\text { refractured to allow } \\
\text { :vater flow }\end{array}$ \\
\hline 21 & TT5, 10.1 & Quartz and calcite & $\begin{array}{l}\text { Hematite, calcite } \\
\text { confirmed with } \mathrm{HCl}\end{array}$ & 0.1 to 0.5 & \\
\hline 22 & TT5, 10.1 & $\begin{array}{l}\text { Predominately calcite } \\
\text { guartz present }\end{array}$ & $\begin{array}{l}\text { Calcite confirmed } \\
\text { with } \mathrm{HCl}\end{array}$ & 1 & \\
\hline 23 & $T T 5,8$ & Predominately guartz & $\begin{array}{l}\text { Hematite and pyrite, } \\
\text { absence of calcite } \\
\text { confirmed }\end{array}$ & 2 to 4 & \\
\hline 25 & TT6, 6.7 & $\begin{array}{l}\text { Predominately calcite } \\
\text { guartz present }\end{array}$ & $\begin{array}{l}\text { Hematite, calcite } \\
\text { confirmed with HCl }\end{array}$ & 1 to 2 & \\
\hline
\end{tabular}

Artificial fractures

$\begin{array}{rlll}9 & \text { Bulk material } & \text { Not available } & \text { Bulk granite } \\ 10 & \text { Bulk material } & \text { Not available } & \text { Bulk granite }\end{array}$


analysis, we identified calcite and quartz as the predominate fracture fill minerals of climax granite. Visual examination identified hematite and pyrite not detected by the $x-r a y$ diffraction. As a check, we chemically tested for the presence of calcite in the fracture fill material. We dropped dilute HCl onto the fracture and monitored the effervescence. Of the natural fractures only core 23 contained no calcite. In the cores used in this study no clay minerals were identified in the fracture fill material. However, chlorite and montmorillinite were identified in other fractures in the Climax Stock granite (Isherwood et al., 1982b). Table 4 summarizes the information on the location of the cores and the composition of the fracture fill material. The bulk granite was composed of quartz, plagioclase, potassium feldspar, biotite, and some minor alteration products. Very little calcite was present in the bulk granite.

Allard et al. (1981) examined the differences in the fracture fill and the bulk material of the Finnsjön granite. As we found in the Climax granite the dominating fracture minerals were quartz and calcite. The composition of the bulk Finnsjön granite resembled the climax granite.

\section{CHEMICAL CHARACTERISTICS OF TRANSPORT SOLUTIONS}

It is expected that the chemistry of the transport solution will affect the sorption of radionuclides on fracture surfaces. Simulated ground water may not accurately reflect the complex chemical composition of natural ground water. Isherwood et al. (1982b) collected and characterized water from seeps in the climax drift. This natural ground water was used for eight of the radionuclide transport runs. The natural ground water was analyzed for elemental composition, oxygen content, $\mathrm{pH}$, and Eh. The Eh and dissolved $\mathrm{O}_{2}$ concentration represent in situ conditions (Table 5). The ground water used in our experiments was equilibrated with the atmosphere. The composition of the climax stock ground water was unusual for a granitic water (Table 5). The level of total dissolved solids, $\mathrm{so}_{4}^{-2}$, and $\mathrm{U}$ was elevated compared with other granitic waters (Allard et al., 1981; Johnston, 1980). The isotopic composition of the uranium identified it as natural, not originating from a nuclear device. Details of the ground-water collection and characterization are reported elsewhere (Isherwood et al., 1982b; Harrar and Raber, 1982). 
Table 5. Climax ground water chemistry.a

$\begin{array}{llll}\mathrm{pH} & 7.3 & \text { Alkalinity } & 163 \mathrm{ppm} \mathrm{HCO}_{\overline{3}} \\ \text { Eh } & 0.41 \mathrm{v} & \text { Conductivity } & 2160 \mathrm{mhos} \\ \text { Dissolved } \mathrm{O}_{2} & <0.02 \mathrm{ppm} & \text { Total dissolved solids } 1900 \mathrm{mg} / 1\end{array}$

\begin{tabular}{|c|c|c|c|}
\hline & ppm & & pppm \\
\hline $\mathbf{N a}$ & 250 & $\mathbf{U}$ & 1.8 \\
\hline $\mathrm{Ca}$ & 283 & Mo & 0.7 \\
\hline $\mathbf{K}$ & 3.4 & Sr & 5.6 \\
\hline $\mathrm{SiO}_{2}$ & 15.8 & $\mathrm{SO}_{4}^{=}$ & 1060 \\
\hline Al & 0.03 & $s=$ & $<0.05$ \\
\hline $\mathrm{Cl}$ & 77 & $\mathbf{F}$ & 0.9 \\
\hline Mg & 0.9 & $\mathrm{Fe}$ & 0.006 \\
\hline $\mathrm{PO}_{4}=$ & $<0.5$ & Cs & 0.002 \\
\hline \multicolumn{4}{|c|}{ [Tritium $=157 \mathrm{pCi} / \mathrm{ml}]}$. \\
\hline
\end{tabular}

a Average composition of ground water collected at climax site CGW-1 (Isherwood et al., 1982b).

Table 6. Conditions of granite core sorption experiments.

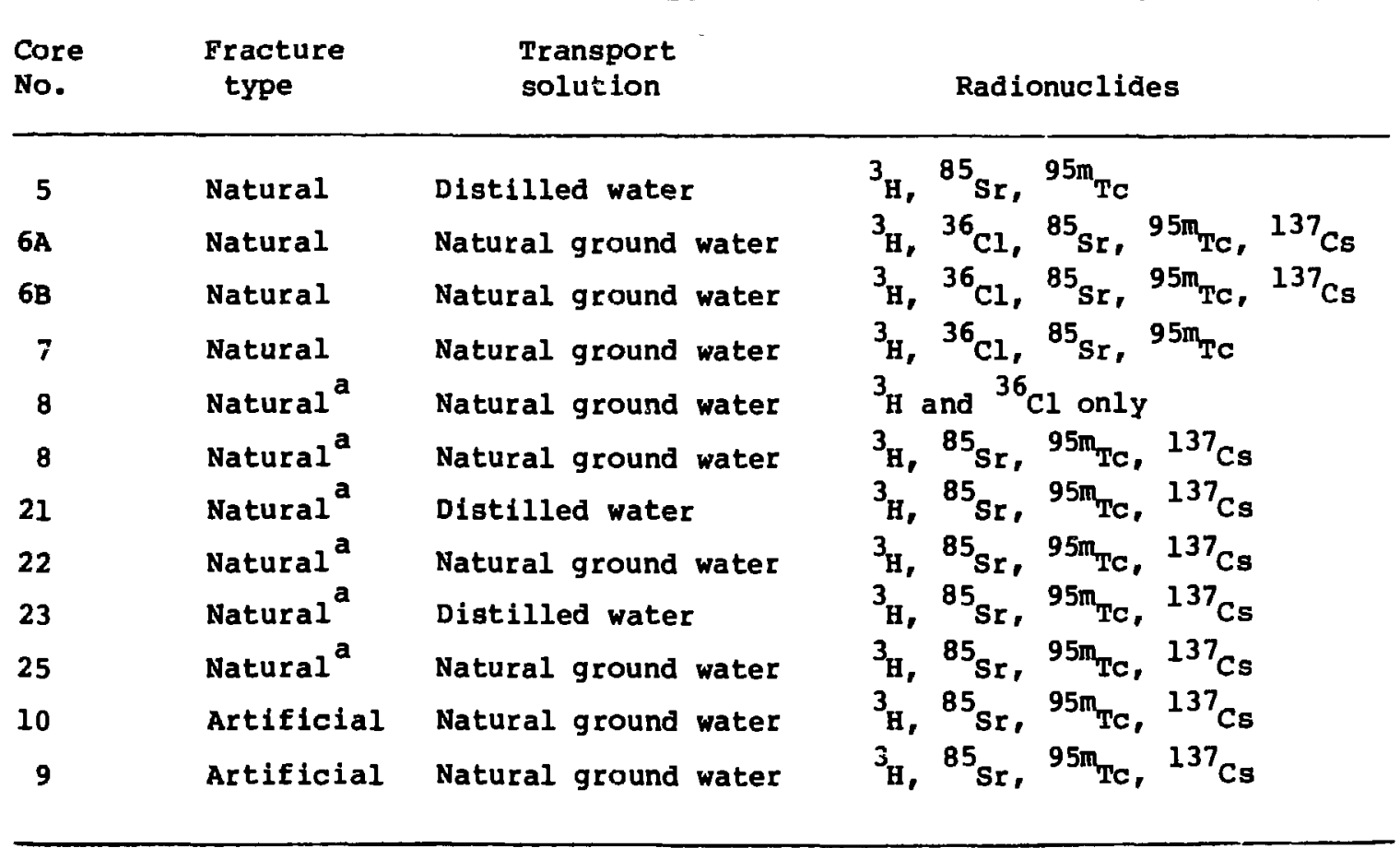

a sealed fracture was refractured to allow water flow. 
The natural leveis of $\mathrm{Ca}, \mathrm{Sr}, \mathrm{Cs}$, and ${ }^{3} \mathrm{H}$ in the Climax ground water are of interest for this study. The possibility of competition for sorption sites between $\mathrm{Ca}$ and $\mathrm{Sr}$ makes the $283 \mathrm{ppm} \mathrm{Ca}$ and $5.6 \mathrm{ppm} \mathrm{Sr}$ important. The effect of the Ca-Sr competition is evident in the lower Sr retention in runs with climax ground water as compared to runs with distilled water. A cesium concentration of $2 \mathrm{ppb}$, while not unusual, is important when comparing distilled water with natural ground water as the transport solution due to competition between ${ }^{137} \mathrm{Cs}$ and natural cs for sorption sites. Our tritium spike concentrations (approximately l. $\mu \mathrm{Ci} / \mathrm{ml}$ ) are not affected by the ambient $157 \mathrm{pCi} / \mathrm{ml}^{3} \mathrm{H}$.

The fracture type, transport solution, and radionuclides for each core run are listed in Table 6 . Cesium was not included in this study until after cores 5 and 7 were completed. As explained previously ${ }^{36} \mathrm{Cl}$ was included in cores 7, 6A, and $6 \mathrm{~B}$ but not used in the data analysis.

DATA REDUCTION

Our data analysis computer program (ORB) performed three main functions:

- Volume and flow rate calculations

- Radionuclide activity calculations

- Graph plotting.

The volume and flow rate calculations were performed using gross and net tube weights and sample collection periods. The tritium activities were input as dpm/ml for each analyzed sample. The background and peak counts, counting period, count date, and half life were used to calculate the cpm/ml (or dpm/ml) of the $\gamma$-emitting radionuclides. The core slice data were calculated in $\mathrm{dpm} / \mathrm{mm}$ and interpolated for slices which were not counted. The above calculations were output graphically and in tabular form.

The graphic output included average flow rate and the activity of each radionuclide plotted vs sample number, time, and cumulative volume. An overlap plot of the designated reference radionuclide with the remaining radionuclides may be requested on the time and cumulative volume plots.

The listing, and sample input and output files for ORB are given in Appendix B. The following are planned improvements to the code which were not carried out when the project was terminated: 
- Bar graphing the core slice data.

- Calculating percent activity remaining in the core.

- Peak maxima calculating.

- Complete calculating of retardation factor.

- A curve fitting routine.

A sample of the elution profiles from core 25 is shown in Figs. 7a through 7c. Data used to generate these plots were used to determine the peak elution volume for the radionuclides. The retardation factor, $R$, for ${ }^{85} \mathrm{Sr}$, $95 \mathrm{~m}_{\mathrm{TC}}$, and ${ }^{137} \mathrm{Cs}$ was determineã by

$$
R=\frac{\text { Elution peak volume of radionuclide } X}{\text { Elution peak volume of tritium }}
$$

The elution peak volume is the cumulative volume of solution that passes through the core between the spike injection and the peak in activity of radionuclide $x$, minus the system dead volume (see Appendix $A$ ). The uncertainties reported arise mainly from the imprecision of the dead volume measurements and the peak locations (if there is scatter in the data points at the peak).

From the calculated $\mathrm{dpm} / \mathrm{mm}$ for the $\gamma$-emitting radionuclides in the core slices we determined the percent of the injected activity retained in the core. We plotted the percentage of injected activity per millimeier of core vs the distance into the core (Fig. 8). These plots depict the sorption of radionuclides along the fracture.

\section{RESULTS}

The elution profiles for ${ }^{95 m} \mathrm{TC}$ and ${ }^{85} \mathrm{Sr}$ indicate little or no retardation of the eluted activity with respect to ${ }^{3} \mathrm{H}$. In the runs of cores $6 \mathrm{~A}$ and $6 \mathrm{~B}$, which contain the same natural fracture, strontium is slightly retarded. For cores $6 \mathrm{~A}$ and $6 \mathrm{~B}$ the calculated ${ }^{85} \mathrm{Sr}$. values fall in the range of $2.5 \pm 1.2$. Technetium is slightly retarded in the core $6 \mathrm{~B}$ run $(R=1.8 \pm 0.4)$. None of the other core runs indicate retardation of $95 \mathrm{~m}_{\text {Te or }}{ }^{85} \mathrm{Sr}$ (Table 7 ).

The behavior of ${ }^{137} \mathrm{Cs}$ is more complex. We used distilled water and a naturally fractured core (core 21 ) and found less than 18 of the ${ }^{137} \mathrm{Cs}$ 
Fractured granite core 25 sorption run with ${ }^{3} \mathrm{H},{ }^{95 \mathrm{~m}} \mathrm{Tc},{ }^{85} \mathrm{Sr},{ }^{137} \mathrm{Cs}$

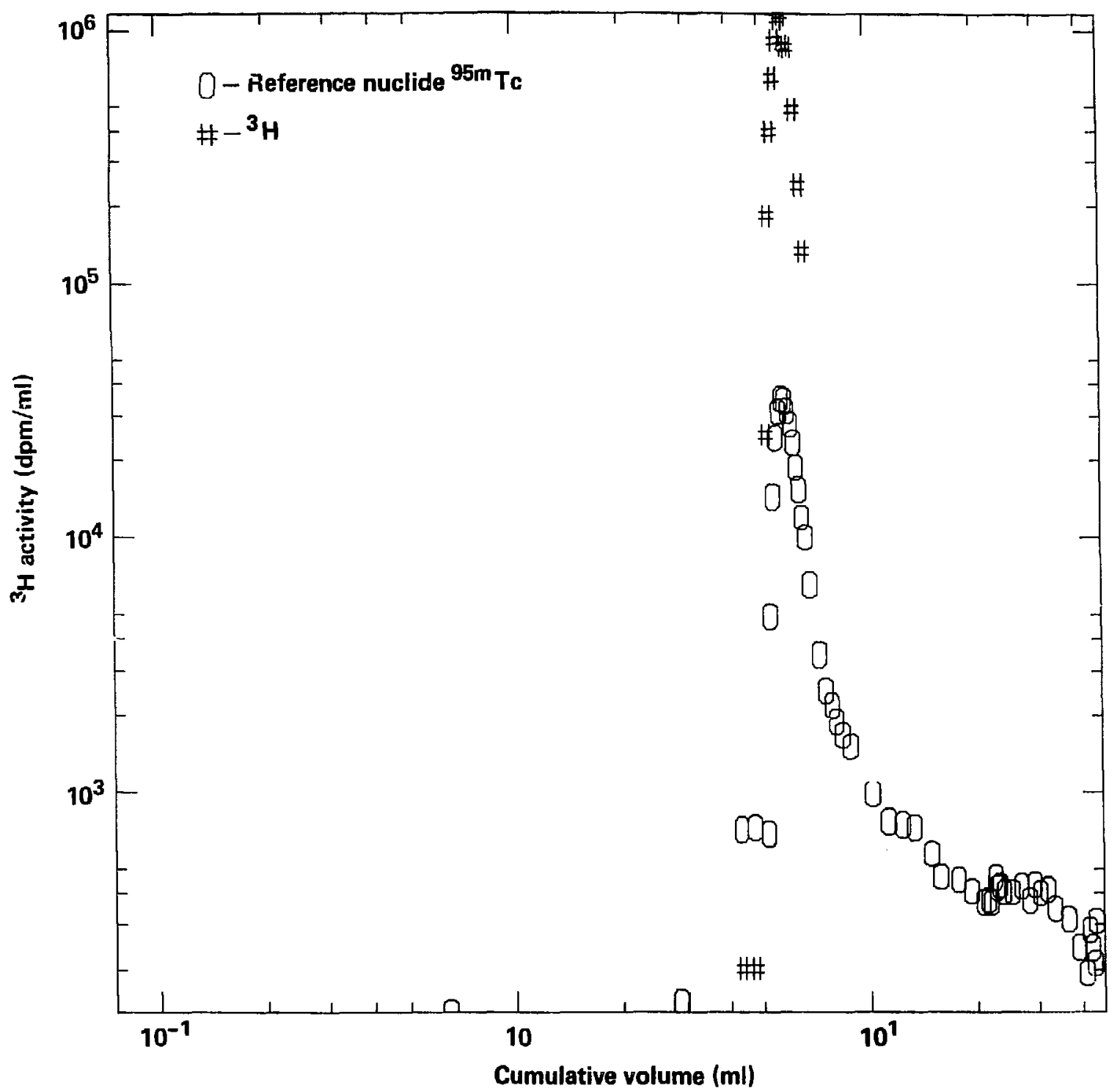

Figure $7 \mathrm{a} .{ }^{3} \mathrm{H}$ and $95 \mathrm{~m}_{\mathrm{TC}}$ over lap plot. 
Fractured granite core 25 sorption run with ${ }^{3} \mathrm{H},{ }^{95 \mathrm{~m}} \mathrm{Tc},{ }^{85} \mathrm{Sr},{ }^{137} \mathrm{Cs}$

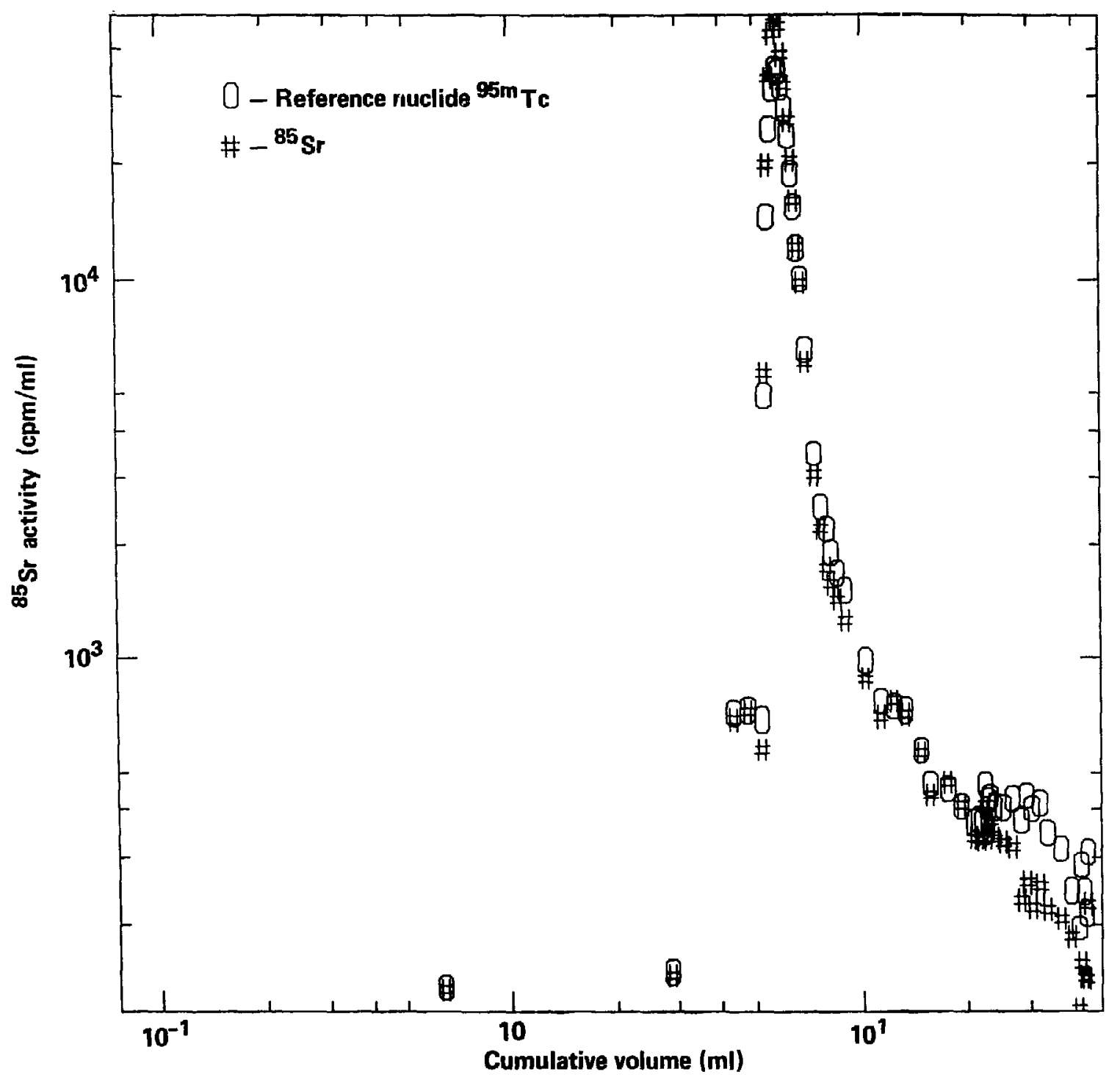

Figure $7 \mathrm{~b} .{ }^{85} \mathrm{Sr}$ and $95 \mathrm{~m}_{\mathrm{Tc}}$ overlap plot. 
Fractured granite core 25 sorption run with ${ }^{3} \mathrm{H},{ }^{95 \mathrm{~m}} \mathrm{Tc},{ }^{85} \mathrm{Sr}$, ${ }^{137} \mathrm{Cs}$

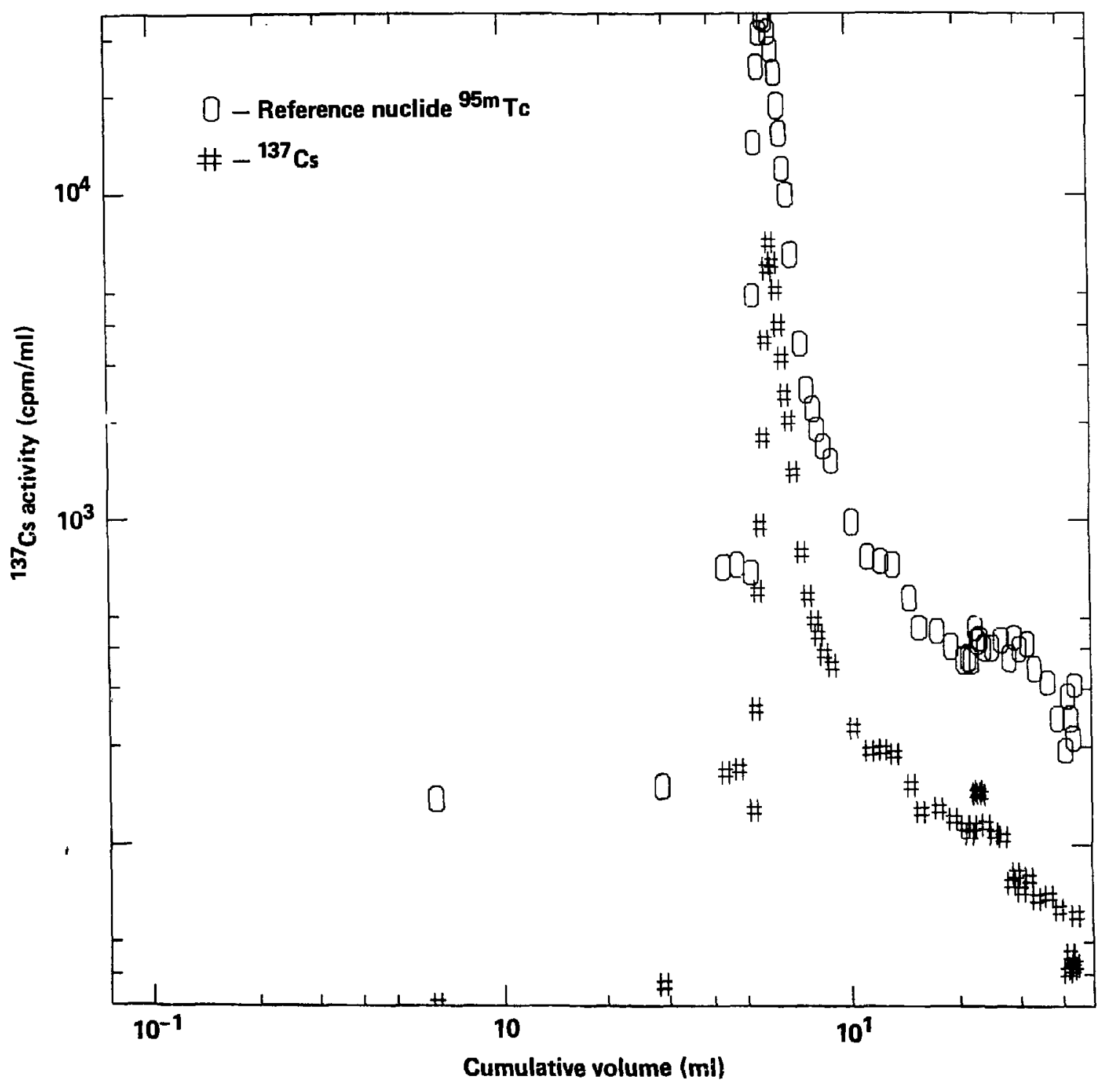

Figure $7 \mathrm{c} .{ }^{137} \mathrm{Cs}$ and $95 \mathrm{~m}_{\mathrm{Tc}}$ over lap plot. 

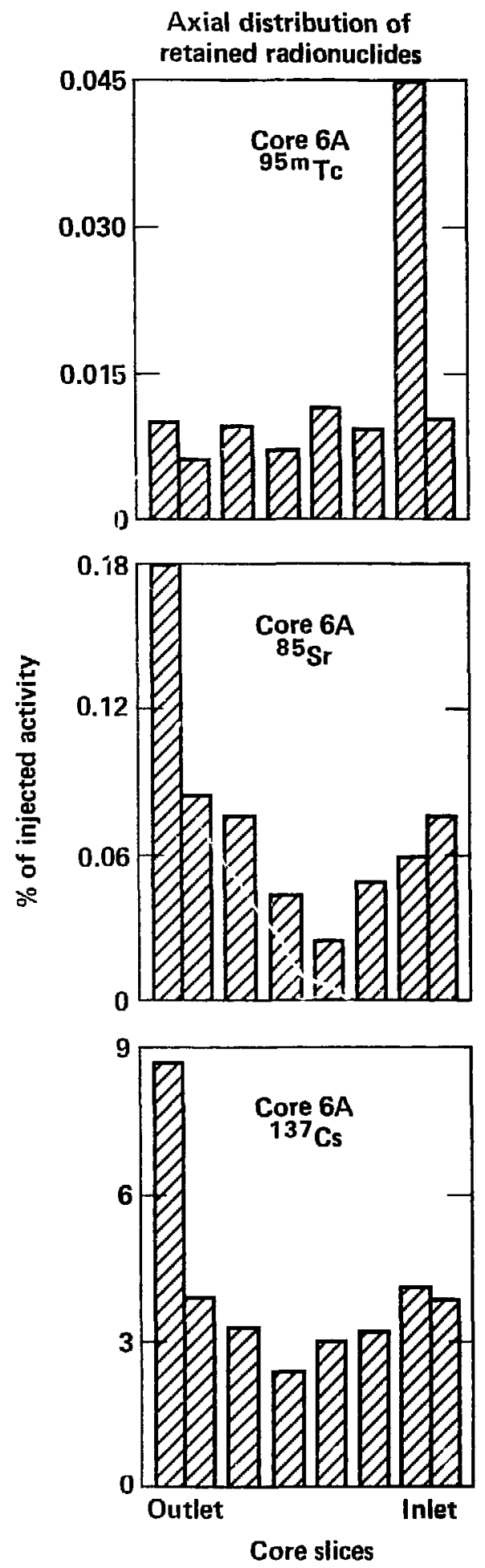

Figure B. Core slice retention plots. 
Table 7. Retardation values.

\begin{tabular}{|c|c|c|c|c|c|}
\hline \multirow{2}{*}{$\begin{array}{l}\text { Core } \\
\text { No. }\end{array}$} & \multirow{2}{*}{$\begin{array}{l}\text { Transport } \\
\text { solution }\end{array}$} & \multirow{2}{*}{$\begin{array}{c}\text { Fracture } \\
\text { type }\end{array}$} & \multicolumn{3}{|c|}{ Retardation (R) values } \\
\hline & & & Sr & TC & Cs \\
\hline 5 & $\begin{array}{l}\text { Distilled } \\
\text { water }\end{array}$ & Natural & $1 \pm 0.2$ & $1 \pm 0.2$ & $\begin{array}{l}\text { Not } \\
\text { included }\end{array}$ \\
\hline 21 & $\begin{array}{l}\text { Distilled } \\
\text { water }\end{array}$ & $\begin{array}{l}\text { Natural } \\
\text { refractured }\end{array}$ & $1 \pm 0.2$ & $1 \pm 0.2$ & $<1000$ \\
\hline 25 & $\begin{array}{l}\text { Distill@d } \\
\text { water }\end{array}$ & $\begin{array}{l}\text { Natural } \\
\text { refractured }\end{array}$ & $1 \pm 0.2$ & $1 \pm 0.2$ & $90 \pm 80$ \\
\hline-- & ------ & ----- & ---- & ---- & ----- \\
\hline 7 & $\begin{array}{l}\text { Natural } \\
\text { ground water }\end{array}$ & Natural & $1 \pm 0.2$ & $1 \pm 0.2$ & $\begin{array}{l}\text { not } \\
\text { included }\end{array}$ \\
\hline $6 A$ & $\begin{array}{l}\text { Natural } \\
\text { ground water }\end{array}$ & $\begin{array}{l}\text { Natural } \\
\text { same as } 6 B\end{array}$ & $2.5 \pm 1.2$ & $1.8 \pm 0.4$ & $120 \pm 50$ \\
\hline $6 \mathrm{~B}$ & $\begin{array}{l}\text { Natural } \\
\text { ground water }\end{array}$ & $\begin{array}{l}\text { Natural } \\
\text { same as } 6 \mathrm{~A}\end{array}$ & $2.9 \pm 0.5$ & $1.8 \pm 0.4$ & $43 \pm 10$ \\
\hline 8 & $\begin{array}{l}\text { Natural } \\
\text { ground water }\end{array}$ & $\begin{array}{l}\text { Natural } \\
\text { refractured }\end{array}$ & $1 \pm 0.2$ & $1 \pm 0.2$ & $5 \pm 25$ \\
\hline 22 & $\begin{array}{l}\text { Natural } \\
\text { ground water }\end{array}$ & $\begin{array}{l}\text { Natural } \\
\text { refractured }\end{array}$ & $1 \pm 0.2$ & $1 \pm 0.2$ & $1 \pm 10$ \\
\hline 23 & $\begin{array}{l}\text { Natural } \\
\text { ground water }\end{array}$ & $\begin{array}{l}\text { Natural } \\
\text { refractured }\end{array}$ & $1 \pm 0.2$ & $1 \pm 0.2$ & $60 \pm 50$ \\
\hline 9 & $\begin{array}{l}\text { Natural } \\
\text { ground water }\end{array}$ & Artificial & $1 \pm 0.2$ & $1 \pm 0.2$ & $1.5 \pm 2$ \\
\hline 10 & $\begin{array}{l}\text { Natural } \\
\text { ground water }\end{array}$ & Actificial & $1 \pm 0.2$ & $1 \pm 0.2$ & $120 \pm 120$ \\
\hline
\end{tabular}

eluted from the core. We estimated the maximum velocity the ${ }^{137} \mathrm{Cs}$ could have and still remain in the core throughout the run. Using this value, we calculated a minimum $R$ value of 1000 . However, in the second natural fracture run with distilled water (core 25) we found 128 of the injected ${ }^{137} \mathrm{Cs}$ eluted through the core. Though not obvious from the ${ }^{95 \pi}$ Tc and ${ }^{137} \mathrm{Cs}$ elution curves in Fig. 7c, the elution peak volume calculated from the data used to generate these curves produced a value of $90 \pm 80$ for the cesium retardation factor. 
With artificial fractures and natural ground water (cores 9 and 10), approximately two-thirds of the injected ${ }^{137} \mathrm{Cs}$ was eluted through the core. The calculated $R$ values are $1.5 \pm 2$ and $120 \pm 120$.

The five naturally fractured cores run with natural ground water also iave a large range of Cs $R$ values. The maximum $R$ value, from core $6 A$, is $120 \pm 50$. In the core 22 run the first ${ }^{137}$ Cs eluted unretarded $(R=1)$ from the core, however, the tailing of the peak was very broad. The $R$ values fall in the range of $60 \pm 60$ for cores $6 \mathrm{~B}, 8$, and 23 . The $R$ values for these natural fractures do not correlate with the fracture fill mineral information or with the fraction of the injected ${ }^{137} \mathrm{Cs}$ retained in the core. For example, cores 6A and 6B (from the same natural fracture) both retained approximately 698 of the injected ${ }^{137} \mathrm{Cs}$ but showed a large difference in cesium retardation. The calculated retardation factors are listed in Table 7.

The large uncertainties in the $R$ values result mainly from uncertainties in the system dead volume determinations. As designed the system has a dead volume $(\sim 1.7 \mathrm{ml})$ which is almost two orders of magnitude larger than the fracture volume. The elution volume used to calculate $R$ is the cumulative volume (after spike injection) minus the dead volume. For unretarded flow this should equal the fracture volume. It is easy to see that even a 58 error in the dead volume causes a large percent error in the resultant elution volumes and hence in retardation value, especially when the errors in peak location and elution volume are compounded.

The percent of the injected activity which remains in the core reveals

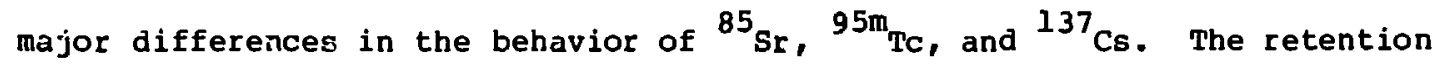
varies from 998 of the injected ${ }^{137} \mathrm{Cs}$ retained in core 21 to less than 0.018 of the injected ${ }^{85} \cdot \mathrm{Sr}$ retained in core 7 (Table 8 ). The amount of injected activity retained in the core varies with the transport solution and fracture minerals.

For those cores run with natural ground water the retention was $\leq 2.48$ of injected ${ }^{85} \mathrm{Sr}$ and $\leq 728$ of injected ${ }^{137} \mathrm{Cs}$. For cores run with distilled water the ${ }^{85} \mathrm{Sr}$ retention ranged from 7.7 to 378 and ${ }^{137} \mathrm{Cs}$ retention ranged from 88 to 998 .

The natural ground water contains $5.6 \mathrm{ppm} \mathrm{Sr}, 283 \mathrm{ppm} \mathrm{Ca}$ (a divalent ion which may affect Sr sorption), and $2 \mathrm{ppb} C s$. The increased sorption in the runs using distilled water can be explained in terms of a nonlinear isotherm. This was shown to apply to cesium (Seitz et al., 1978) and may also apply to 
Table 8. Radionuclide retention in cores.

\begin{tabular}{|c|c|c|c|c|c|c|}
\hline $\begin{array}{l}\text { Core } \\
\text { No. }\end{array}$ & $\begin{array}{l}\text { Transport } \\
\text { solution }\end{array}$ & $\begin{array}{l}\text { Fracture } \\
\text { type }\end{array}$ & $\begin{array}{l}\quad \text { \& Sx } \\
\text { retained } \\
\text { in core }\end{array}$ & $\begin{array}{l}\quad \text { TC } \\
\text { retained } \\
\text { in core }\end{array}$ & $\begin{array}{l}\text { \& Cs } \\
\text { retained } \\
\text { in core }\end{array}$ & Comments \\
\hline 5 & $\begin{array}{l}\text { Distilled } \\
\text { water }\end{array}$ & Natural & 7.7 & 0.1 & $\begin{array}{l}\text { Not included } \\
\text { in spike }\end{array}$ & $\begin{array}{l}\text { Spike inadvertently } \\
\text { contained brine salts }\end{array}$ \\
\hline 21 & $\begin{array}{l}\text { Distilled } \\
\text { water }\end{array}$ & Natural & 37 & 9.2 & 99 & $\begin{array}{l}5.08 \text { of TC and } 398 \text { of Cs } \\
\text { injected retained on inlet slice }\end{array}$ \\
\hline 25 & $\begin{array}{l}\text { Distilled } \\
\text { water }\end{array}$ & Natural & 10 & 12 & 88 & \\
\hline $6 A$ & $\begin{array}{l}\text { Natural } \\
\text { ground water }\end{array}$ & Natural & 1.3 & 0.3 & 68 & \\
\hline $6 B$ & $\begin{array}{l}\text { Natural } \\
\text { ground water }\end{array}$ & Natural & 2.3 & 0.6 & 69 & \\
\hline 7 & $\begin{array}{l}\text { Natural } \\
\text { ground water }\end{array}$ & Natural & $<0.01$ & 30 & $\begin{array}{l}\text { Not included } \\
\text { in spike }\end{array}$ & $\begin{array}{l}\text { Tc activity found on particles } \\
\text { blown out of core at end of run }\end{array}$ \\
\hline 8 & $\begin{array}{l}\text { Natural } \\
\text { ground water }\end{array}$ & Natural & 2.2 & 46 & 72 & $\begin{array}{l}228 \text { of Tc injected retained on } \\
\text { inlet slice }\end{array}$ \\
\hline 22 & $\begin{array}{l}\text { Natural } \\
\text { ground water }\end{array}$ & Natural & 2.4 & 4.2 & 70 & $\begin{array}{l}3.48 \text { of Tc injected retained on } \\
\text { inlet slice }\end{array}$ \\
\hline 23 & $\begin{array}{l}\text { Natural } \\
\text { ground water }\end{array}$ & Natural & 2.1 & 34 & 32 & $\begin{array}{l}138 \text { of } \mathrm{T}_{\mathrm{C}} \text { injected retained on } \\
\text { inlet slice }\end{array}$ \\
\hline 9 & $\begin{array}{l}\text { Natural } \\
\text { ground water }\end{array}$ & Artificial & 0.6 & 12 & 38 & \\
\hline 10 & $\begin{array}{l}\text { Natural } \\
\text { ground water }\end{array}$ & Artificial & 1.0 & 21 & 31 & \\
\hline
\end{tabular}

NOTE: Less than 0.18 of total activity was retained on Halthane jackets. 
strontium. The combined effect of calcium and strontium could account for the higher retention in distilled water compared to ground water $r$ uns.

The ${ }^{137} \mathrm{Cs}$ retention also varies with fracture type. For the naturally fractured cores run with natural ground water $(6 \bar{A}, 6 \mathrm{~B}, 8$, and 22) the cores retained 68 to 728 of the ${ }^{137} \mathrm{Cs}$ injected. The fracture fill minerals in these cores contained calcite and quartz. One other naturally fractured core (core 23) contained no calcite in the fracture fill material, and retained only 328 of the ${ }^{137} \mathrm{Cs}$ when run with natural ground water.

The lower cs sorption for the cores with no calcite along the fracture should not be directly attributed to the absence of calcite. Allard et al. (1982) reports a low sorption of Cs on calcite (118) compared with an $88 \%$ sorption on granite or 918 on biotite (a major mineral component of granite). As explained in the next section, the autoradiographs actually show lower sorption in the regions of the fracture where calcite is present. Other minerals associated with calcite in the fracture fill material may contribute to the Cs sorption in cores $6 \mathrm{~A}, 6 \mathrm{~B}, 8$, and 22 .

A chemical stripping technique helped us to better understand the Cs sorption. As mentioned, dilute $\mathrm{HCl}$ was applied to the core slices to check for the presence of calcite. On core 25 the HCl was collected, the slices ware rinsed, and the rinses were collected. The $\mathrm{HCl}$ and rinses were $\gamma$-counted. To dissolve the iron and manganese oxides the slices were broken along the fracture and contacted for $6 \mathrm{hr}$ at $96^{\circ} \mathrm{C}$ with a solution of $0.04 \mathrm{~mole} / 1$ hydroxylamine hydrochloride in 25 vols acetic acid (Tessler et al., 1979). These solutions, rinses, and the rinsed slices were also r-counted. Only ${ }^{137} \mathrm{Cs}$ was detected since the ${ }^{85} \mathrm{Sr}$ and $95 \mathrm{~m}_{\mathrm{Tc}}$ had decayed away. The results are presented in Fig. 9.

The HCl should remove all ${ }^{137} \mathrm{Cs}$ sorbed by ion exchange and associated with the calcite. The average of this ${ }^{137} \mathrm{Cs}$ was $8 \pm 48$ of the total ${ }^{137} \mathrm{Cs}$ retained by the core, while $62 \pm 58$ was removed along with the iron and manganese oxides and $31 \pm 68$ was not removed by these solutions. It is possible that this last fraction includes material sealed in place by the potting epoxy; however, it is striking that as much as one third of the ${ }^{137} \mathrm{Cs}$ has become immobilized after a relatively short contact time. In fact, most of the ${ }^{137} \mathrm{Cs}$ left in the core is evidently not available for desorption via ion exchange but can be removed by dissolution of the iron and manganese oxides. 


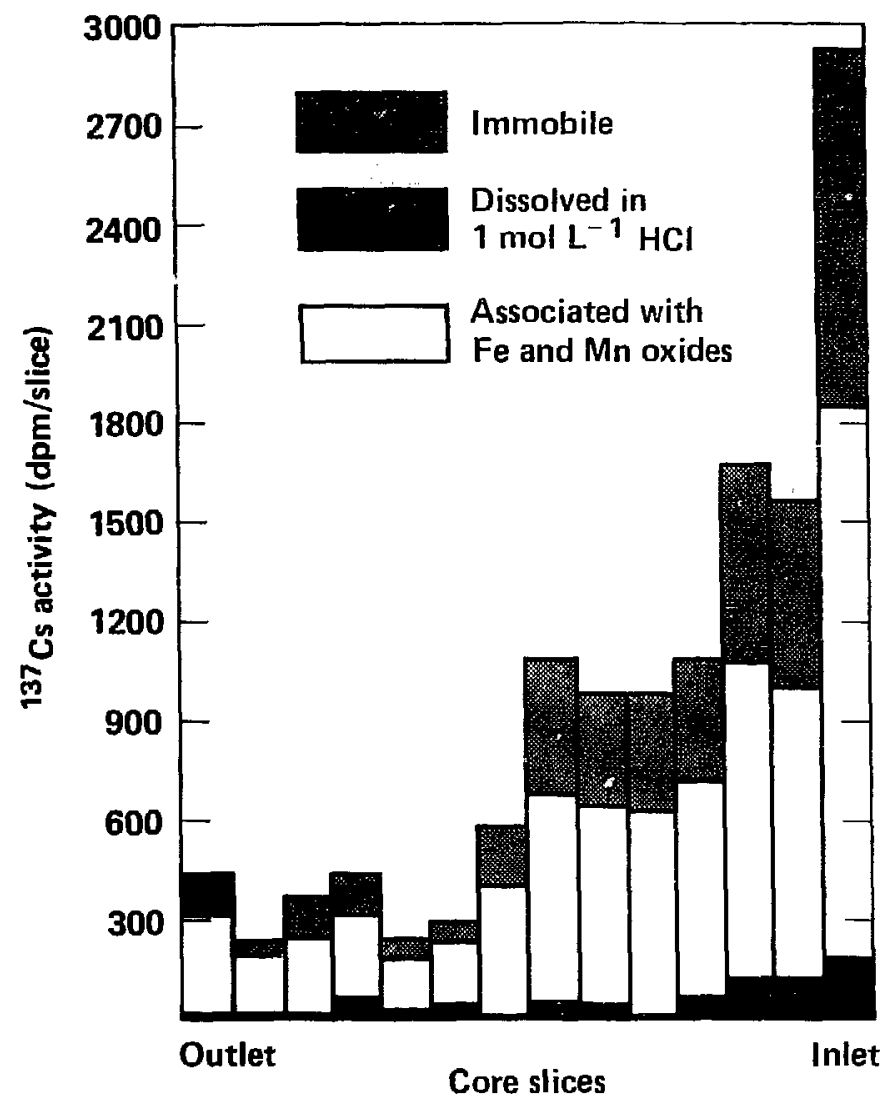

Figure 9. Chemical stripping profile of ${ }^{137} \mathrm{Cs}$ sorption.

The retention of ${ }^{95 \mathrm{~m}} \mathrm{Tc}$ in the cores is not easily related to the transport solution or fracture fill material. Three of the natural fractures run with natural ground water (cores 7, 8, and 23) retained from 30 to 408 of the injected ${ }^{95} \mathrm{~m}_{\mathrm{TC}}$. The other three natural fractures run with natural ground water (cores $6 \mathrm{~A}, 6 \mathrm{~B}$, and 22) retained from 0.3 to 4.28 of the injected 95m $\mathrm{m}_{\mathrm{TC}}$. The natural fractures run with distilled water (cores 21 and 25) retained from 9 to 128 of the injected ${ }^{95 m} \mathrm{Tc}$. In core 5 , also run with distilled water, only 0.18 of the ${ }^{95 \mathrm{~m}} \mathrm{Tc}$ was retained; however this may have been the result of inadvertently using brine to make up the 0.5 -ml spike.

The artificial fractures (cores 9 and 10) run with natural ground water retained from 12 to 218 of the injected ${ }^{95 m}$ Tc. On several cores $(8,21,23$, and 22) 40 to 808 of the ${ }^{95 \mathrm{~m}}$ Tc retained by the core was found on the inlet slice. Axial distribution plots show the spread of the retained activity through the core. Figure $B$ displays a sample plot. The high sorption of 
$95 \mathrm{~m}_{\text {Tc }}$ at the inlet end of the core is typical. Vandergraaf's review (1982a) suggests moderate sorption of Tc on granite $\left(K_{d}=28 \mathrm{ml} / \mathrm{g}\right)$ (LANL, 1979). Our results confirm technetium sorption on bulk granite.

\section{AUTORADIOGRAPHY}

Autoradiographs were made of the slices from core 25 (a natural fracture run with distilled water). The autoradiographs (Figs. 10-13) show that sorption of the radionuclides occurred only in the fracture except for the faces of the core where the radionuclides can contact the bulk granite.

The procedure for obtaining the autoradiographs is similar to that described by Vandergraaf and Abry (1982b). Slices of core 25 were contacted with glass slides coated with an Ilford $\mathrm{K5}$ emulsion for $144 \mathrm{~h}$. After exposure, the plates were developed in Kodak D19 developer for $10 \mathrm{~min}$ with constant agitation, followed by 5 min in a kodak stop bath, $2^{n}$ min fixing in Kodak fixer, and $25 \mathrm{~min}$ washing in running distilled water.

The photographs and autoradiographs were photographed on kodak Panatomic $\mathrm{X}$ film through a WILD macroscope using transmitted light, and printed to give a linear magnification of $4 x$. The autoradiographs are positive; i.e., the dark areas are the exposed areas and correspond to those containing the sorbed radionuclides. Since the core was sliced after the experiment, no autoradiographs could be made to check for natural radioactivity before contact with the radionuclide solutions. However, past experience has shown that exposure well in excess of four weeks is needed to register normal natural radioactivity levels on Ilford plates.

The autoradiographs (Figs. 10-13) clearly show that sorption occurred primarily along the fracture, and with the exception of the inlet slices (Fig. 10) and outlet slices (Fig. 11), did not spread beyond this fracture. The inlet face and oulet face sorb radionuclides before and after the spike enters the fracture. No sorption is evident on the outer surface of the core. This shows that the ground-water flow was restricted to the fracture, and no bypass occurred between the core and the Halthane jacket. This substantiates results obtained in earlier runs with Rhodamine B dye.

Sorption along the width of the fracture is not uniform. Near the inlet part of the core where gross inhomogeniety of the bulk rock can be seen from the optical photographe (Fig. 12), enhanced sorption in the fracture appears 

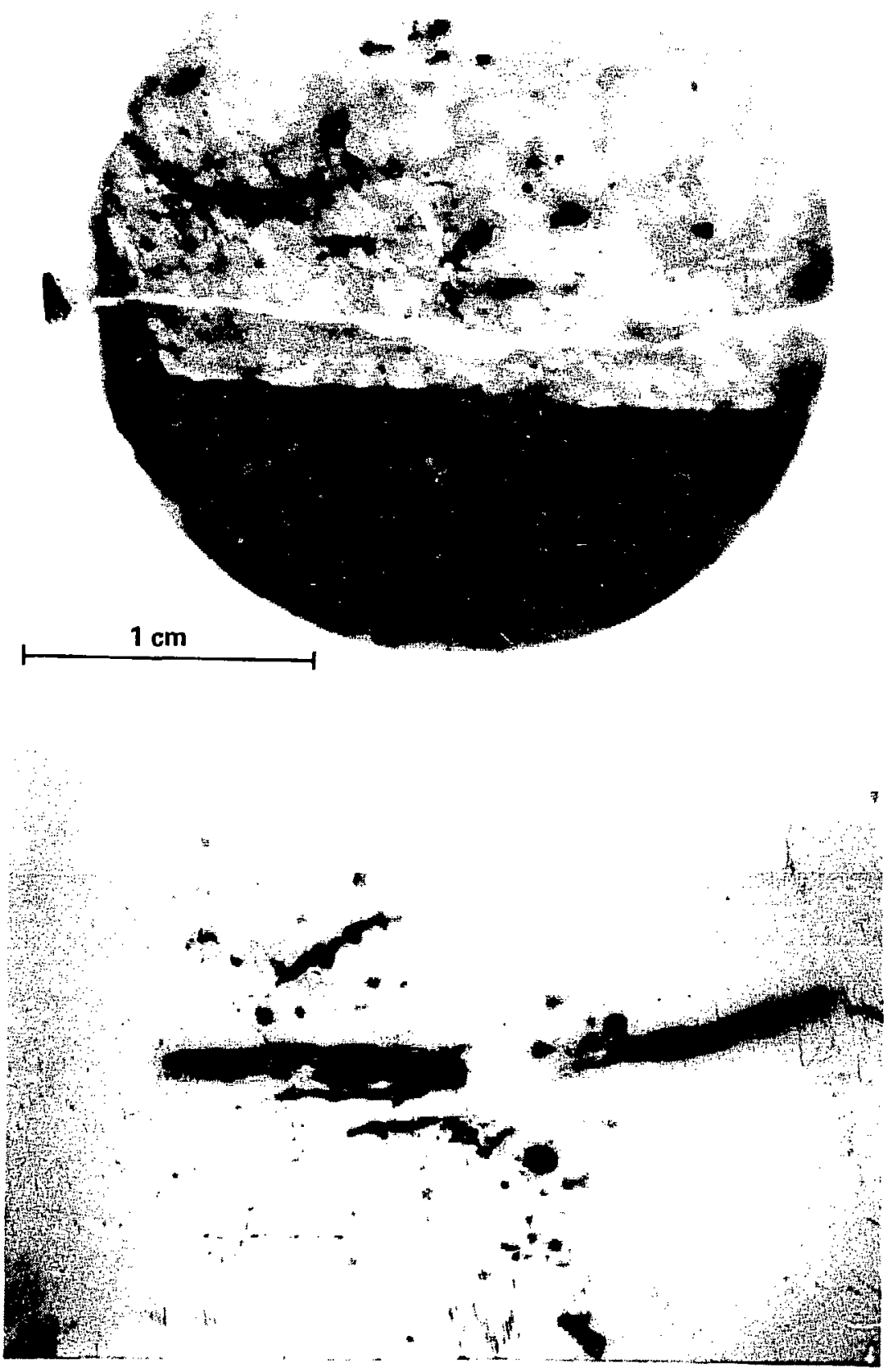

Figure 10. Photograph and autoradiograph of solution inlet slice of naturally fractured granite core--No. 25 (sorption occurred both in fracture and on bulk granite inlet face of core). 

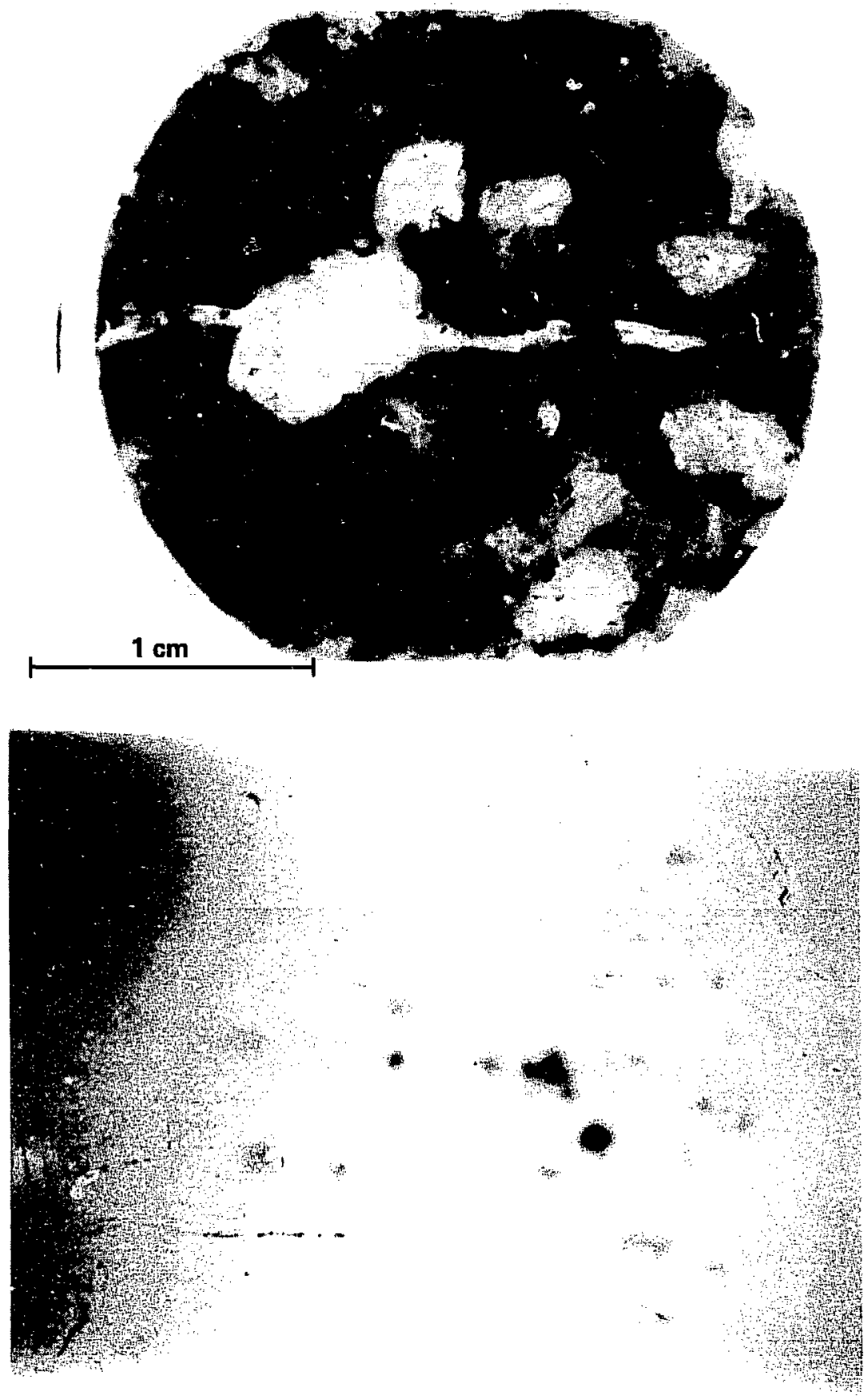

Figure 11. Photograph and autoradiograph of solution outlet slice of naturally fractured granite core--No. 25 (sorption occurred both in fracture and on bulk granite outlet face of core. 

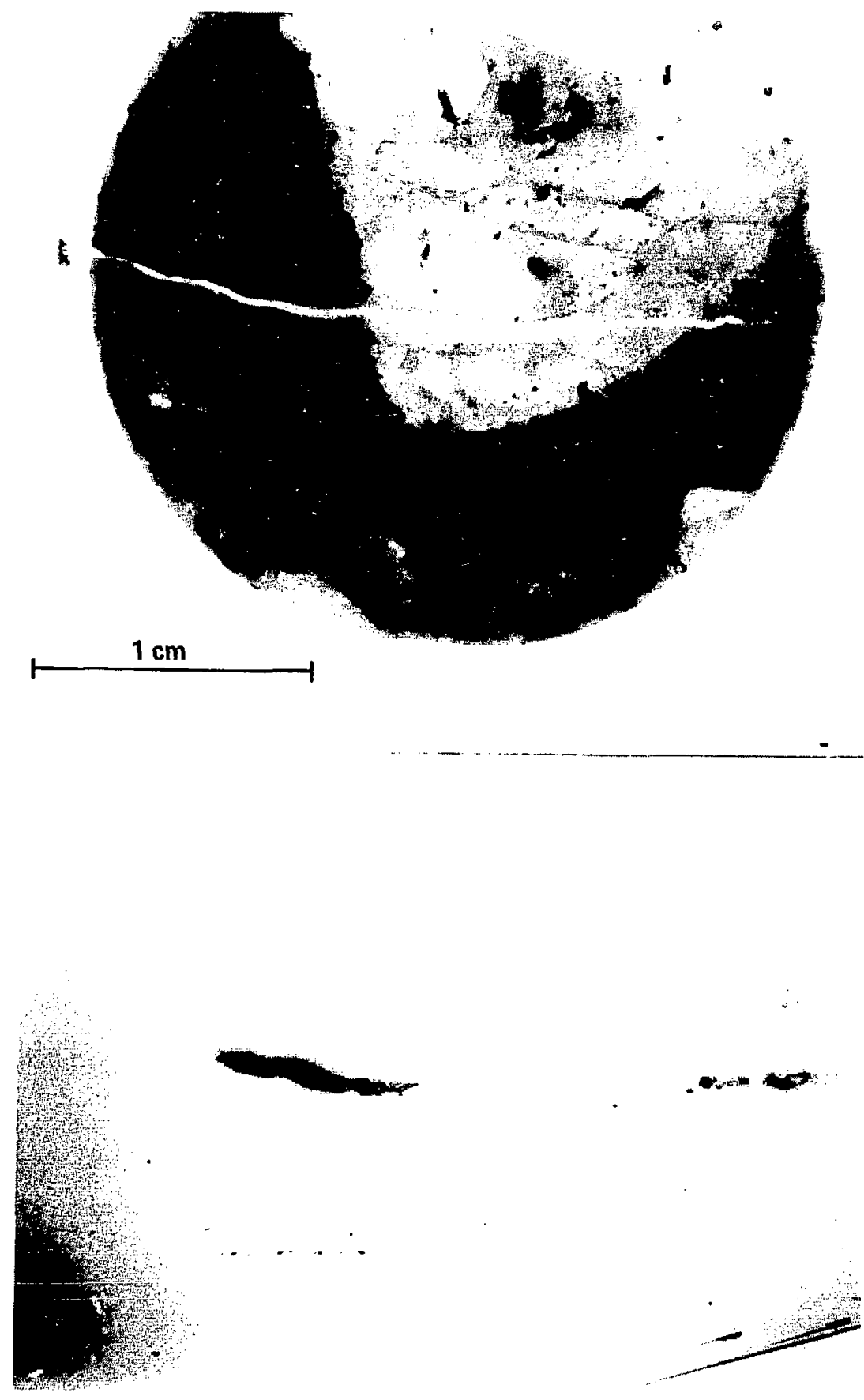

Figure 12. Photograph and autoradiograph of interior slice of naturally fractured granite core--No. 25 (sorption

occurred only along fracture, mostly along ferromagnesium-rich mineral portion of core). 

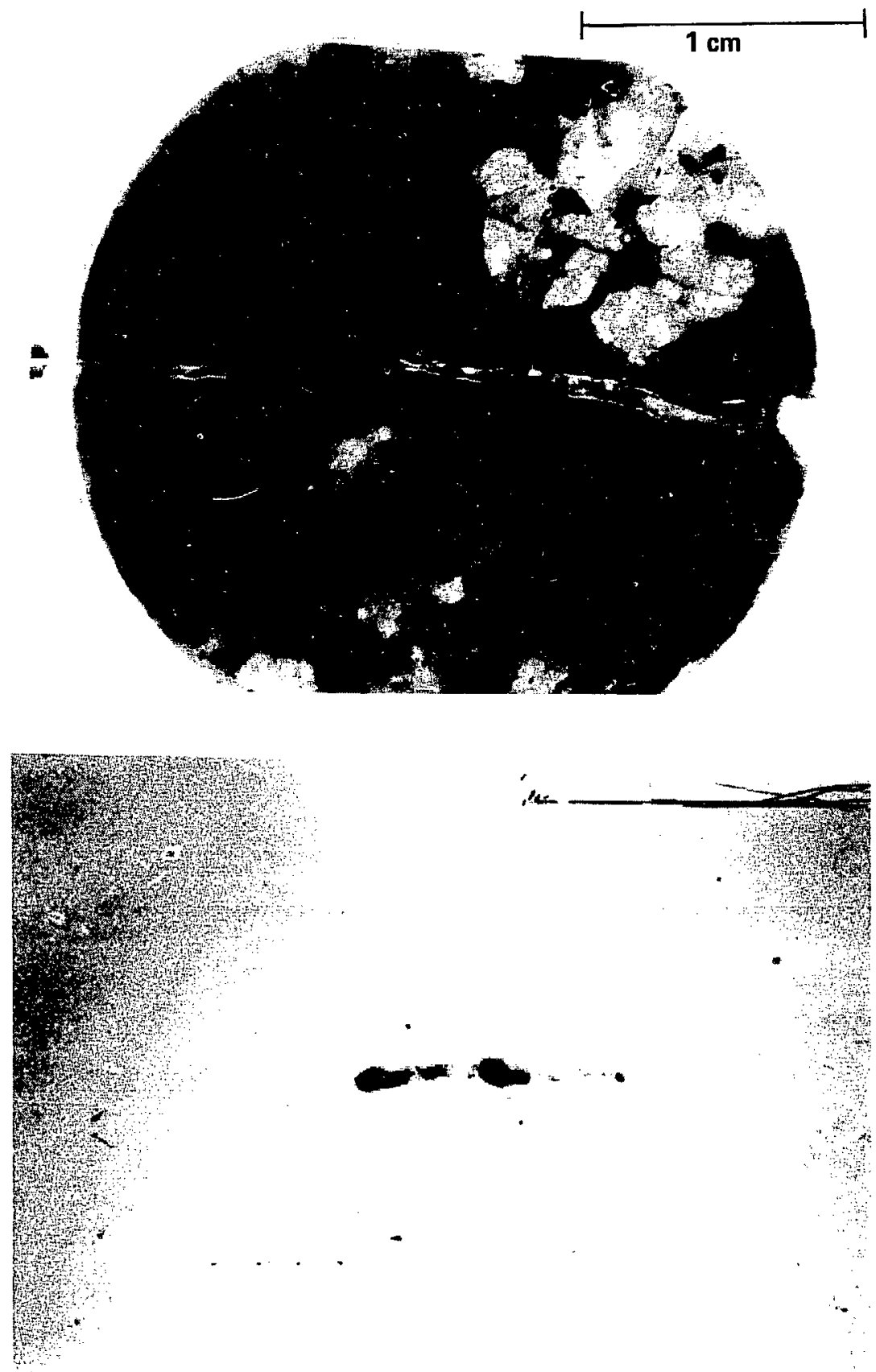

Figure 13. Photograph and autoradiograph of interior slice of naturally fractured granite core--No. 25 (sorption occurred only along fracture; specific sorption minerals are difficult to determine). 
to correlate with the ferromagnesium rich mineral regions (the dark areas in the optical photographs) and is very low in the feldspar region. This agrees with other studies (Vandergraaf et al., 1982b,c). closer to the outlet, sorption again occurs on specific sites in the fracture (Fig. 13).

It is difficult to determine which minerals are the prime sorption sites. To check for sorption by calcite, dilute $\mathrm{BCl}$ was dropped onto the fracture fill material of core 25 after the autoradiography was completed. The effervescence, an indication of the presence of calcite, was greatest in the regions with the lowest sorption.

At the time the radionuclide transport experiment was carried out, 888 of the ${ }^{137}$ Cs was retained by the core, compared to 108 of the ${ }^{85} \mathrm{Sr}$ and 128 of the ${ }^{95 \mathrm{~m}}$ Tc injected. During the time between the core sorption $r$ un and the autoradiography most of the ${ }^{85} \mathrm{Sr}$ and ${ }^{95 \mathrm{~m}} \mathrm{Tc}$ had decayed away. Therfore, the activity registered by the photographic emulsion is mostly ${ }^{137} \mathrm{Cs}$, which is known to sorb on biotite.

SUGGESTED FUTURE STUDIES

The results of our experiments suggest some necessary improvements in equipment and alternate procedures. The major difficulty arises from the ratio of large dead volume to fracture volume.

To safely apply confining pressures up to $35 \mathrm{MPa}$ to the cores, the end pieces and core are housed in a large brass vessel. These end pieces add to the dead volume. Also, the fittings for the pressure transducers add dead volume as do the lines from the spike loop and to the fraction collector. It is possible to add the spike directly into the fracture (Neretnieks et al., 1981) and remove the solution from the opposite end of the fracture as it accumulates. This reduces the dead volume significantly. However, Neretnieks does not apply confining pressure to the core.

In addition to improving the ratio of dead volume to fracture volume, increasing the area of the fractures will increase the residence times of the radionuclides in the fracture and provide a larger reaction surface. Neretnieks et al. (1981) has used cores $30 \mathrm{~cm}$ long by $20 \mathrm{~cm}$ in diameter. Future drilling procedures must be carefully planned to acquire satisfactory large samples of natural fractures. 
The autoradiography results show sorption on the faces of the core (Figs. 10 and 11). The core slice counting indicated a large percent of the

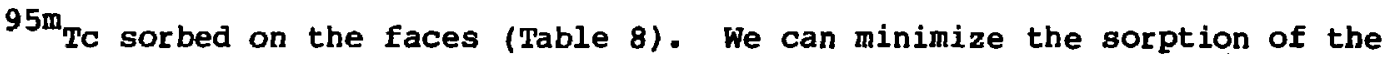
tracers on the face of the core by sealing the exposed bulk rock and leaving the fracture free. Halthane 73-18 (the polyurethane adhesive used to jacket the cores) has proven to be nonsorbing and forms a tight bond with the rock surface. A thin coat of Halthane 73-18 across the faces of the core, leaving the fracture free, would prevent loss of the tracer before it enters the fracture.

Our work is a first step in studying the effects of transport solution composition on the sorption of radionuclides. Much more work is necessary to understand the mechanisms involved. The idea of competition between strontium and calcium for sorption sites should be studied. The influence on migration by the high level of dissolved solids and high $\mathrm{SO}_{4}^{-2}$ in the climax ground water has not been investigated. The effect of the transport solution conposition on the radionuclide speciation (especially technetium) should be considered (Paguette et al., 1980).

In studying the effects of fracture fill material on radionuclide sorption, more details of the fracture fill composition are necessary. The reduction in ${ }^{137}$ Cs retention in the cores with no calcite in the fractures points out one of many unanswered questions.

\section{IN BRIEF}

Following equipment modifications to adapt the core sorption apparatus to the study of fracture flow, radionuclide transport tests were performed on eleven fractured granite cores. To document the effects of fracture fill material and transport solution on radionuclide transport and sorption, our experiments used natural and artificial fractures, with natural ground water

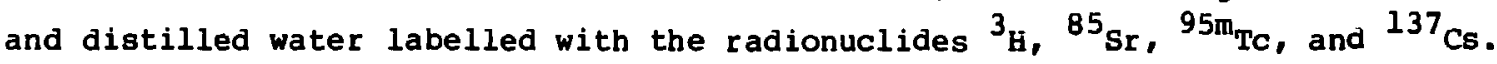

Strontium-85 shows, little or no retardation relative to tritiated water under our experimental conditions. With natural ground water as the transport solution, less than 2.58 of the injected ${ }^{85} \mathrm{Sr}$ is retained in the core. With distilled water as the transport solution, 7.7 to 378 of the injected ${ }^{85} \mathrm{Sr}$ is retained in the core. We hypothesize a nonlinear isotherm combined with a competition for sorption sites between calcium and strontium to be the cause. 
A correlation between ${ }^{85} \mathrm{Sr}$ retention in the cores and fracture fill material is not evident.

Technetium shows little or no retardation relative to tritiated water. The amount of ${ }^{95 \mathrm{~m}}$ Tc retained in the cores does not correlate with type of transport solution or fracture fill material. In agreement with other studies we detect technetium sorption on the bulk granite (Vandergraaf, 1982a).

Cesium shows a varied retardation from core to core relative to tritiated water. The amount of retardation does not correlate with the type of transport solution or fracture fill material in any clear way. With natural ground water as the transport solution, less than 738 of the injected ${ }^{137} \mathrm{Cs}$ is retained in the core. With distilled water as the transport solution, 88 to 998 of the injected ${ }^{137} \mathrm{Cs}$ is retained in the core. We hypothesize a nonlinear isotherm to be the cause of the increased cesium retention with distilled water.

With natural fractures containing calcite 68 to 728 of the injected ${ }^{137} \mathrm{Cs}$ is retained in the core. With artificial fractures and a natural fracture containing no calcite, 31 to 388 of the injected ${ }^{137} \mathrm{Cs}$ is retained in the core. The autoradiographs show lower sorption in the regions where calcite is present.

Hydraulic conductivity measurements follow the size effect trend predicted by witherspoon (1979). Using Darcy's law, fracture apertures were calculated for each core and ranged from 18 to $60 \mu \mathrm{m}$. These apertures are typical of fractures in granite. Isherwood et al. (1982a) measured apertures of 20 and $30 \mu \mathrm{m}$ in fractures in the Piledriver drift.

The vast majority of radionuclide sorption data comes from static tests on crushed rock. Whereas refined dynamic tests are needed to provide more reproducible experimental values, our test simulate natural conditions by using natural fracture surfaces with fracture fill and flowing transport solutions. Our results demonstrate the importance of transport solution compositions and fracture fill material, especially for Cs sorption. The lack of correlation between retardation and sorption from core to core indicates further studies are needed to determine whether there are different mechanisms occurring or whether the lack of correlation is simply due to the natural heterogeneity of the fractures.

A fundamental concern is whether laboratory fracture flow results accurately reflect the transport of radionuclides in the natural environment. Field test of radionuclide transport in fractures have been proposed by 
several workers (Isherwood et al., 1982a; Neretnieks et al., 1982). The field results are vitally important to determine the validity of laboratory dynamic transport tests.

\section{ACKNOWLEDGMENTS}

The authors wish to thank $V$. Janet Brown for her conscientious technical assistance, Philip Barben for his development of the ORB computer program, Ken Tickner for making the autoradiographs of the core slices, Homer Weed for his initial work in core sorption, Robert Buddemeier for his technical guidance, and David Coles and Larry Ramspott for their technical advice, encouragement, and enthusiasm. 
Allard, B., S. A. Larson, Y. Alkinsson, E. L. Tullborg, M. Karlsson,

K. Andersson, and B. Torstenfelt, 1981, "Minerals and Precipitates in

Fractures and their Effects on the Retention of Radionuclides in

Crystalline Rocks," proceedings of the Workshop on Near-Field Phenomena in Geologic Repositories for Radioactive Waste from Nuclear Energy Agency Organization for Economic Cooperation and Development.

Coles, D. G., H. C. Weed, and J. D. Tewhey, 1980, Geochemical Studies of Sorption and Transport of Radionuclides in Rock Media, Lawrence Livermore National Laboratory, Livermore, Calif., UCRL-52929.

Connolly, J. A., 1981, Observations on the Geology of the Climax Stock Granite

About the Spent Fuel Test Site, Area 15, NTS, Nevada, Masters Thesis, University of Arizona, Tucson, Ariz.

Hammon, H. G. and L. P. Althouse, 1977, Development of Halthane Adhesives for Phase-3 Heapons: Status Report No. 2, Lawrence Livermore National

Laboratory, Livermore, Calif., UCID-17348.

Harrar, J., and E. Raber, 1982, "Borehole Collector for In-Situ Analysis of Ground Water," Ground Water, 20: 479-481.

Isherwood, D., E. Raber, R. Stone, D. Lord, N. Rector, R. Failor, 1982a, Engineering Test Plan for Field Radionuclide Migration Experiments in Climax Granite, Lawrence Livermore National Laboratory, Livermore, Calif., UCRL-53286.

Isherwood, D., J. Harrar, E. Raber, 1982b, Characterization of Climax Granite Ground Water, Lawrence Livermore National Laboratory, Livermore, Calif., UCRL-53309.

Iwai, K. 1976, Fundamental Studies of Fluid Flow through a Single Fracture. Ph.D. Thesis, University of California, Berkeley, Calif., 208 pp. Johnston, L. M., 1980, Geochemistry of Ground Water in Crystalline Rocks: A Review, National Hydrology Research Institute, Ottawa, Canada. Los Alamos National Laboratory, New Mexico, 1980, Laboratory Studies of Radionuclide Distributions Between Selected Ground Waters and Geologic Media, compiled by B. R. Erdal, Los Alamos Quarterly Report, LA-8330-PR, pp. 15-23.

MacLean, S. C., D. G. Coles, and H. C. Weed, 1978, The Measurement of Sorption Ratios for Selected Radionuclides on Various Geologic Media, Lawrence Livermore National Laboratory, Livermore, Calif., UCID-17928. 
Neretnieks, I., T. Eriksen, and P. Tahtinen, 1981, "Tracer Movement in a Single Fissure in Granitic Rock--Some Experimental Results and Their Interpretation," to be published in Scientific Basis for Nuclear Waste Management, Volume 5 .

Neretnieks, I. and L. Birgersson, 1982, Diffusion in the Matrix of Granite Rock Field Test in the Stripa Mine, internal report for Swedish Nuclear Fuel Supply Co., KBS, Stockholm Sweden.

Paquette, J., J. A. K. Reid, and E. L. J. Rosinger, 1980, Review of Technetium Behavior in Relation to Nuclear Waste Disposal, Aimic Energy Canada Limited, Manitoba, Canada, TR-25.

Pratt, H. R., H. S. Swolfs, W. F. Brace, A. D. Black, and J. W. Handin, 1977

"Elastic and Transport Properties of In-Situ Jointed Granite," Int. J. Rock Mech. Min. Sci. and Geomech. Abstr. 14:35-45.

Seitz, M. G., P. G. Rickert, S. M. Fried, A. M. Friedman, and M. J. Steindler, 1978, Studies of Nuclear Waste Migration in Geologic Media, Argonne National Laboratory, ANL-78-8.

Tessler, A., P. G. C. Campbell, and M. Bisson, 1979, "Sequential Extraction Procedure for the Speciation of Particulate Trace Metals," Anal. Chem., $\underline{51}: 844-851$.

Vandergraaf, T. T., 1982a, Compilation of Sorption Coefficients for

Radionuclides on Granite and Granitic Rocks, Atomic Energy Canada Limited, Manitoba, Canada, TR-120.

Vandergraaf, T. T., D. R, M. Abry, 1982b, "Radionuclide Sorption on Drill Core Material from the Canadian Shield," Nuc. Technol. 57:399-412. Vandergraaf, T. T., D. R. M. Abry, and C. E. Davis, 1982C, The Use of

Autoradiography in Determining the Distribution of Radionuclides Sorbed on Thin Sections of Plutonic Rock from the Canadian Shield, Atomic Energy Canada Limited, Manitoba, Canada, 7460, Chemical Geology. Weed, H. C., R. F. Koszykowski, L. L. Dibley, and I. Murray, 1981a, An Apparatus for Measurement of Radionucliae Transport Rates in Rock Cores, Lawrence Livermore National Laboratory, Livermore, Calif., UCID-19200. Weed, H. C., F. Bazan, J. Fontanilla, J. Garrison, J. Rego, and A. M. Winslow (1981b), Radionuclide Transport in Sandstones with WIPP Brine, Lawrence Livermore Natiunal Laboratory, Livermore, Calif., UCRL-85508. 
Witherspoon, P. A., C. H. Amick, and J. E. Gale, 1977, Stress-Flow Behavior of a Fault Zone with Fluid Injection and Withdrawal, Mineral Engineering Report No. 77-1, University of California, Berkeley, Calif.

witherspoon, P. A., C. H. Amick, J. E. Gale, and K. Iwai, 1979, Observations of a Potential Size--Effect in Experimental Determination of Hydraulic Properties of Fractures, Lawrence Berkeley Laboratory, Berkeley, Calif., LBL-8571. 
A detailed description of the core sorption apparatus is available in Weed et al. $(198 \mathrm{lb})$. The following equipment changes converted the core sorption apparatus used to study radionuclide transport in brine through sandstone into the system used to study radionuclide transport in ground water through fractured climax stock granite. The first changes improved our ability to measure the hydraulic properties of the fracture flow. Previously a needle valve on the outlet side of the core (Fig. Al) throttled the flow of solution. The valve affected the fluid pressures in the core by acting as a second aperture. We removed the valve to allow for a more natural flow pattern through the fractured core.

The previous pressure transducers (Fig. Al) spanned a range of 0-15,000 psi and were placed on the inlet and outlet sides of the core. A Taber Model 2404 pressure transducer, spanning 0-300 psi at \pm 18 precision, now measures the inlet fluid pressure. A validyne Model DP pressure transducer 15-50, spanning 0-100 psi at \pm 1 o precision, now measures the differential fluid pressure. The hydraulic conductivities calculated using the new transducers pressure measurements allow us to determine the fracture apertures of the cores to two significant figures (Tables 3 and 4).

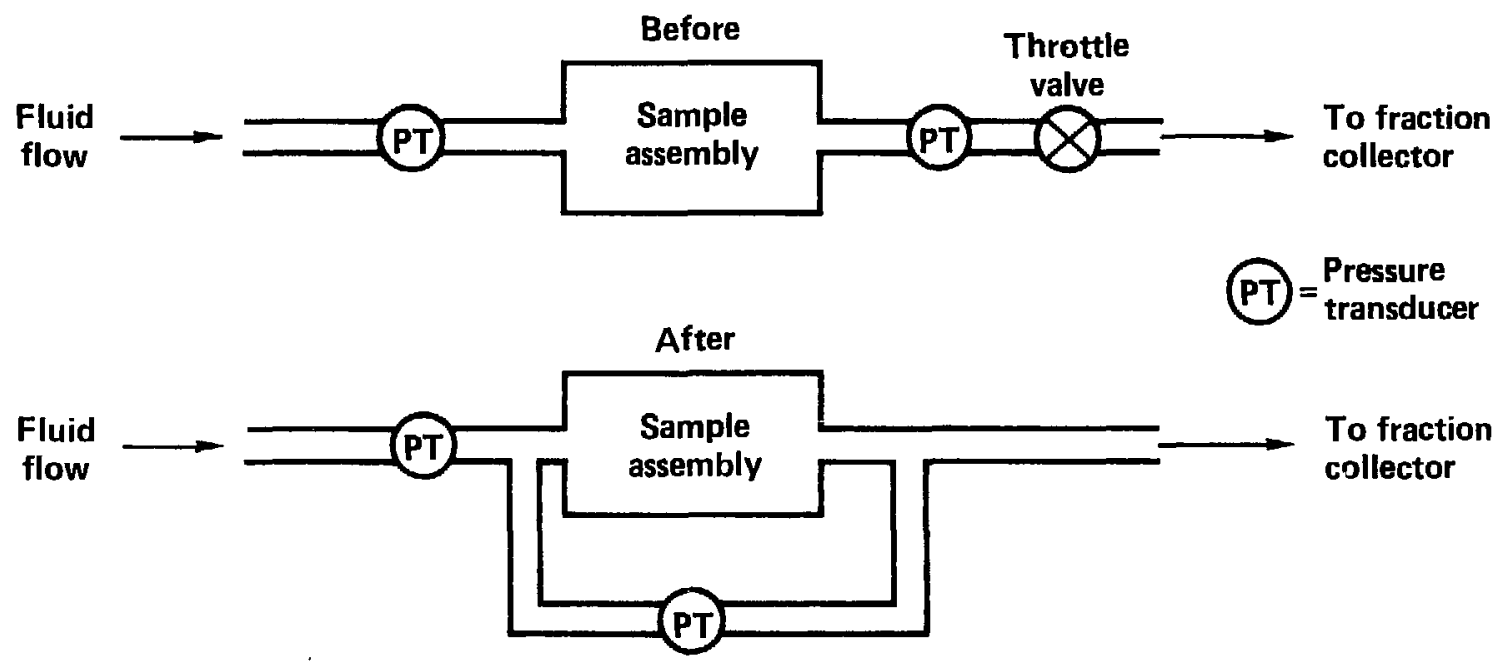

Figure Al. Schematic of changes made in pressure transducer arrangement and removal of throttle valve. 
The lowest reliable flow rate obtained by the standard Altex Model 100 dual piston positive displacement pumps is approximately $0.03 \mathrm{ml} / \mathrm{min}$. This is approximately $0.07 \mathrm{~m} / \mathrm{d}$ for a fracture area of $6.45 \mathrm{~cm}^{2}$. Reducing this flow rate more closely simulates the low flow expected for a repository site and increases the residence time of the radionuclides in the core. To obtain a slower flow rate we modified an Altex Model 100 pump by replacing the drive motor with a $\times 10$ slower motor. The modified pump can deliver a flow at $0.001 \mathrm{ml} / \mathrm{min}$. However, this rate is not stable. This modified pump was used on all cores except 5 and 7 with an average flow rate of $0.002 \pm 0.0005 \mathrm{ml} / \mathrm{min}$. We redesigned the inlet end fitting to improve the connection to the pressure transducers. The modification reduced the system dead volume and simplified the connection. The previous fraction collector was replaced with a Gilson Race Track Model. The new fraction collector holds more sample tubes, has a more precise timer, and is more reliable than the previous unit. We developed a simpler method of injecting the Halthane 73-18 unpolmerized mixture into the jacketing mold using syringes held in a caulking gun.

To prepare the spike solutions, aliguots of standard "carrier-free" radionuclide solutions of ${ }^{85} \mathrm{Sr},{ }^{95 \mathrm{~m}} \mathrm{TC}$, and ${ }^{137} \mathrm{Cs}$ were heated to dryness in a volumetric flask using an infrared lamp. The radionuclides were added in $\mu \mathrm{Ci} / \mathrm{ml}$ levels. This low concentration will avoid swamping the fracture wtih Sr, TC, or Cs far above natural levels. Known amounts of tritiated water and transport solution diluted the activity to the desired level. When distilled water was used as the transport solution, $\mathrm{Sr}$ and $\mathrm{Cg}$ carrier (5 ppm $\mathrm{Sr}$ and $1 \mathrm{ppm} \mathrm{Cs)} \mathrm{was} \mathrm{added} \mathrm{to} \mathrm{the} \mathrm{spike.} \mathrm{The} \mathrm{natural} \mathrm{Cs} \mathrm{and} \mathrm{Sr} \mathrm{levels} \mathrm{in} \mathrm{the} \mathrm{Climax}$ Stock ground water act as the carrier in the spikes made with natural ground water. No special carrier was added for Tc since decay corrected $\gamma$-counts did not show a loss of Tc from the spike solutions over time.

To determine the activity levels of the radionuclides in the spike $100 \mu 1,150 \mu l$, and $200 \mu l$ aliguots of each spike were pipetted onto filter papers and counted on calibrated Ge(Li) detectors. A sample of the spike was also submitted for ${ }^{3} \mathrm{H}$ analysis.

The elution volume for a radionuclide includes the volume of the fracture plus the volume of the tubing and end fittings. The volume of the tubing and end fittings is called the system dead volume. The measured parameter from the experiments is the total elution volume for the radionuclides. We must know the system dead volume to determine the volume of the fracture only. 
The procedure for a dead volume measurement run is very similar to the normal fractured granite core runs. A reference core made of dense alumina replaces the granite core in the experimental setup (Fig.1). A center bore hole with a volume of $5.8 \times 10^{-3} \mathrm{~cm}^{3}$ is drilled into the core. A radionuclide spike is loaded into the spike loop. The flow rate and sample collection rate are adjusted to get the best volume resolution. After the spike injection, the cumulative volume and activity are monitored until the activity level peaks and returns to the background level. The measured dead volume is the volume of solution collected between the spike injection and the peak of the eluted activity. 
The ORB computer program was written to handle the large amount of data generated by a core sorption run. ORB performs three main functions:

- Volume and flow rate calculations.

- Radionuclide activity calculations.

- Graph plotting.

The input file is extensive and allows for a great deal of flexibility. The front end input information consists of:

Titles.

- Radionuclide identification and half-life (days).

- Concentration in spike $(\mathrm{dpm} / \mathrm{ml})$ and calibration data for the activity calculation.

- Dead volume (ml).

- Spike volume (ml) and spike injection point (time (minutes) and sample number].

- Transport solution density $(g / \mathrm{m} l)$.

- Decay calculation zero time (Julian date).

- Time increments for sampling (minutes).

Following this for each sample the input information consists of :

- Sample number.

- Gross and tare sample tube weight (g).

- Number of $\bar{B}^{-}$emitters analyzed for in that sample.

- Number of $Y$ emitters analyzed for in that sample.

If $\beta^{-}$or $\gamma$ analysis were performed on a given sample the input information consists of :

- Activity (dpm/ml) for $\beta^{-}$emitters.

- Count data necessary to calculate the activity (cpm/ml or $\mathrm{dpm} / \mathrm{ml}$ ) for $\gamma$ emitters.

The core slice data input consists of:

- Number of slices.

- Saw blade thickness (mm).

- Radionuclide identification (for the $\gamma$ emitters only).

- Slice thickness (mm).

- Radionuclide activity (dpm/slice). 
ORB creates three output files, INECHO, OUTPUT, and a graph file. INECHO contains the input file information in tabular form with headings. OUTPIT is a tabulation of the calculated values. The first part of OUTPUT lists by sample number:

- Calculated volumes (ml), net for each sample and sumulative.

- Flow rates $(\mathrm{ml} / \mathrm{min})$, instantaneous and average.

- Time (minutes) since the sample collection staried.

The second part of OUTPUT lists the core slice activities (dpm/ $\mathrm{mm}$ ) and slice thickness (mm) for each $\gamma$ emitting radionuclide. Finally OUTPUT lists the decay-corrected radionuclide activities $(\mathrm{dpm} / \mathrm{ml}$ or $\mathrm{cpm} / \mathrm{ml}$ ) for the analyzed samples.

ORB automatically prints the graphing file after each run of the program. The plots consist of:

- Average flow rate vs sample number, time, and cumulative volume (see for example, Fig., Bl).

- Activity for each radionuclide vs sample number, time, and cumulative volume (see for example, Figs. B2 and B3).

- Overlap plots of the activity of the chosen reference radionuclide and each radionuclide vs time and cumulative volume (see, for example, Fig. B4).

ORB is an interactive program allowing the user the following options: Identifying the input file.

- Log-linear or lóg-log plots.

- Core slice analysis (yes or no).

- Overlap plotting routines (yes or no).

The program periodically updates the status of the run for the user. ORB identifies errors in the input file and informs the user of the problem and the result to the run. Following is an example of the ORB-user dialog for a a typical run with the listing and the input and output files. (Figures Bl through $\mathrm{B} 4$ are some of the graphs from the ${ }^{3} \mathrm{H},{ }^{36} \mathrm{Cl}$ run of core 8 used as short examples of the graphing output file.) 
Fractured granite core 8 sorption run with ${ }^{3} \mathrm{H}$ and ${ }^{36} \mathrm{Cl}$ only

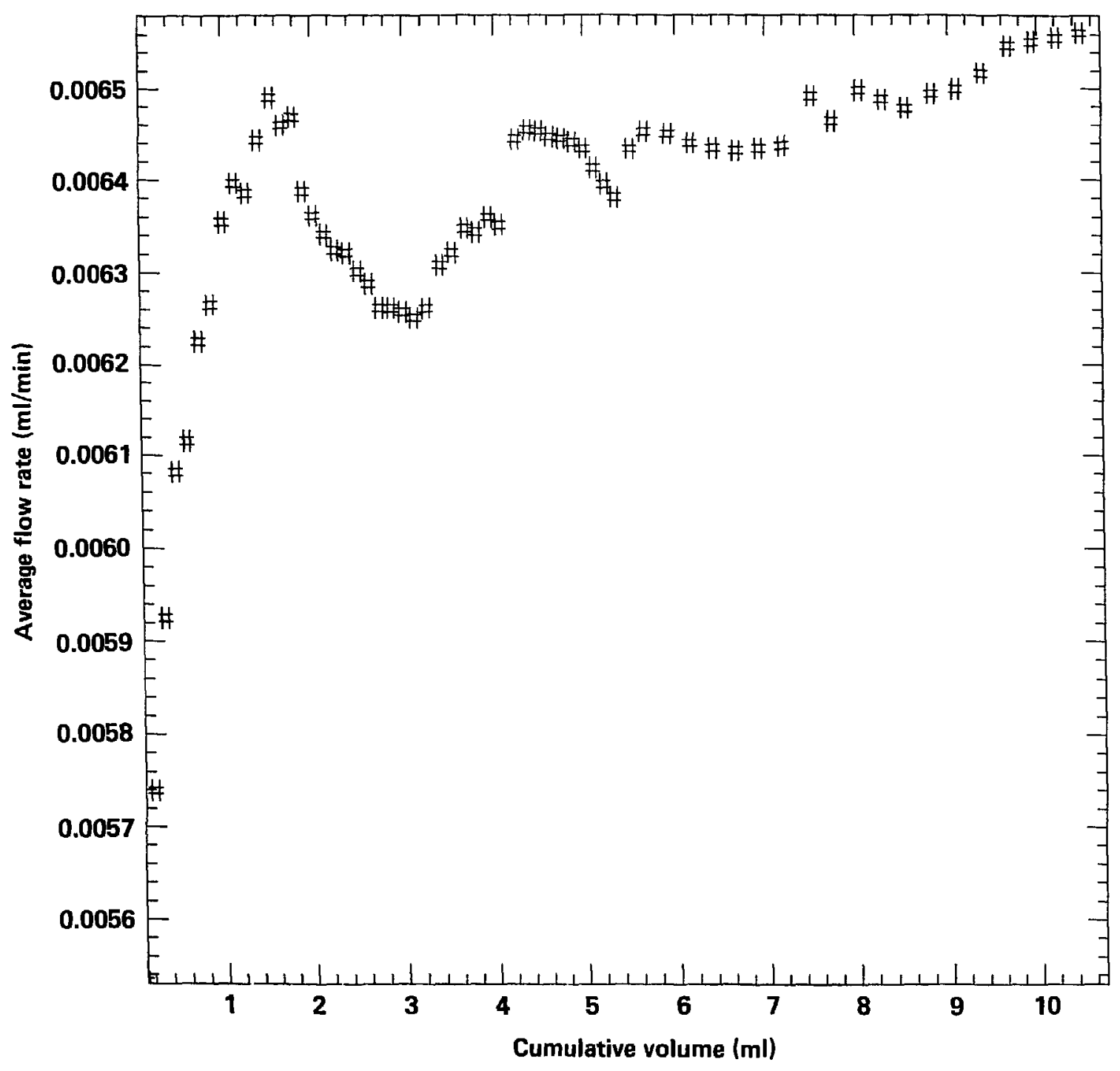

Figure B1. Average flow rate vs cumulative volume (a complete output file also includes plots of average flow rate vs sample number and time). 
Fractured granite core 8 sorption run with ${ }^{3} \mathrm{H}$ and ${ }^{36} \mathrm{Cl}$ only

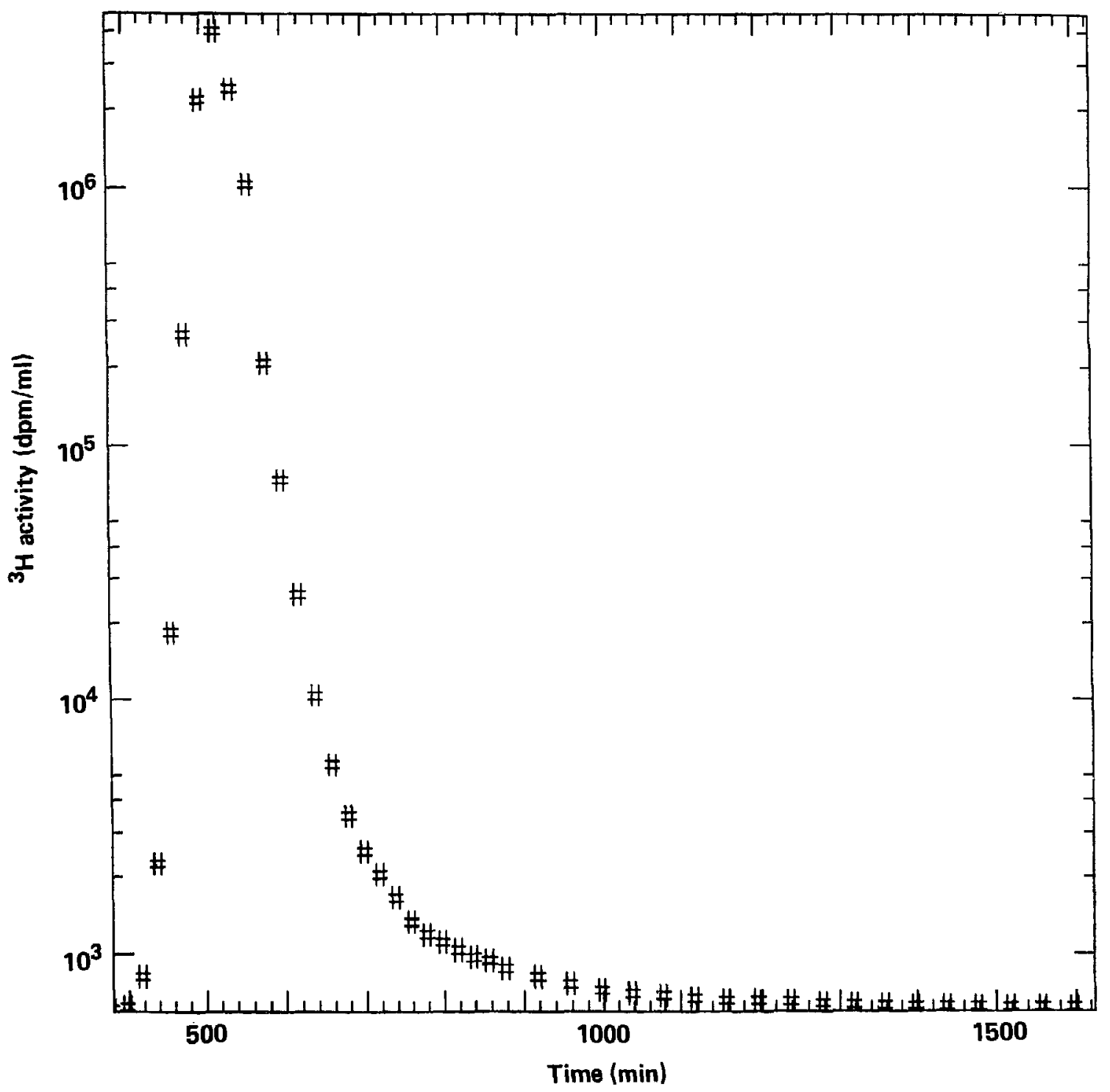

Figure B2. ${ }^{3} \mathrm{H}$ activity vs time (a complete output file includes plots of the activity of each radionuclide vs sample number, time, and cumulative volume). 
Fractured granite core 8 sorption run with ${ }^{3} \mathrm{H}$ and ${ }^{36} \mathrm{Cl}$ only

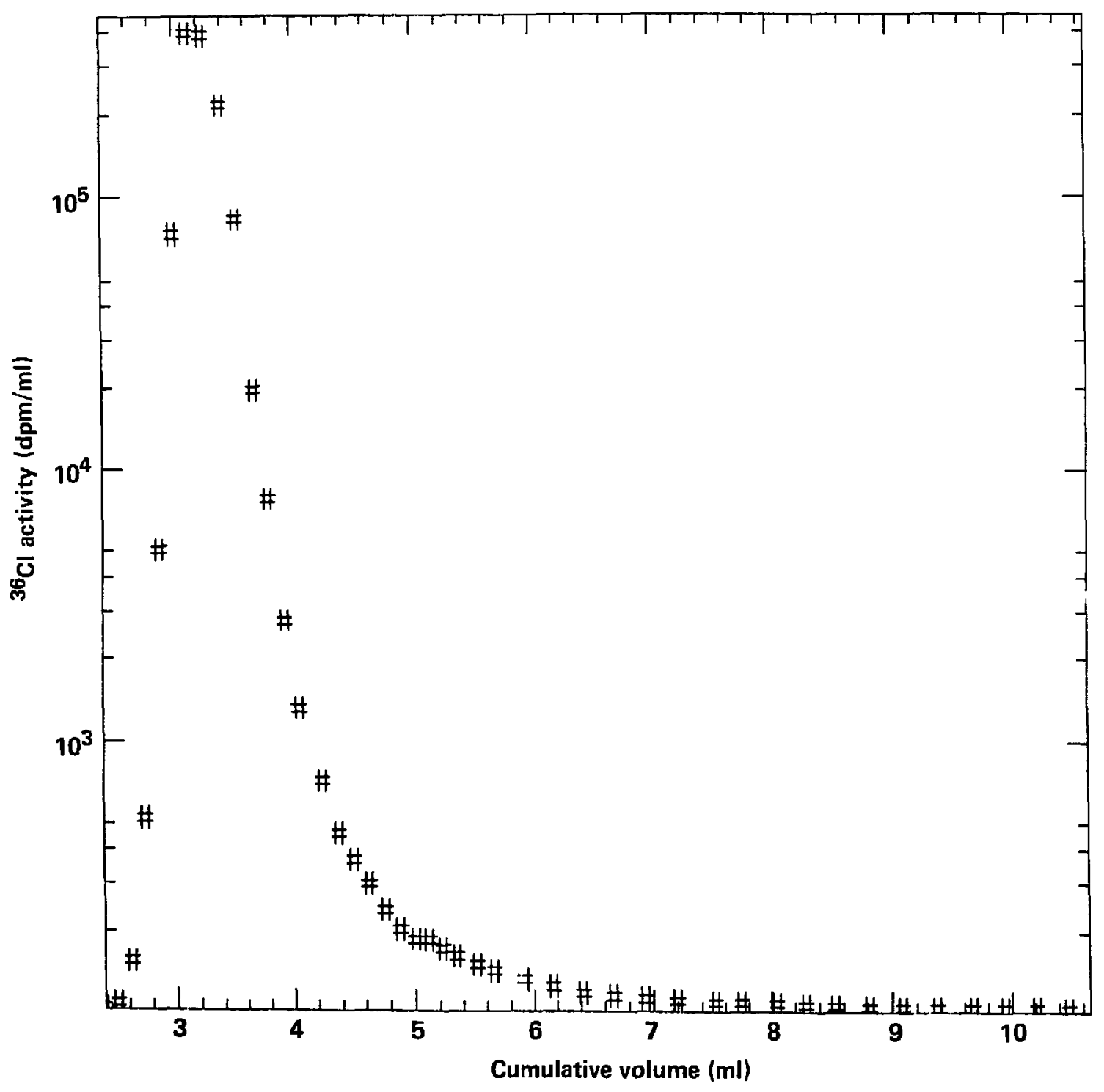

Figure $\mathrm{B} 3 .{ }^{36} \mathrm{Cl}$ activity vs cumulative volume. 
Fractured granite core 8 sorption run with ${ }^{3} \mathrm{H}$ and ${ }^{36} \mathrm{Cl}$ only

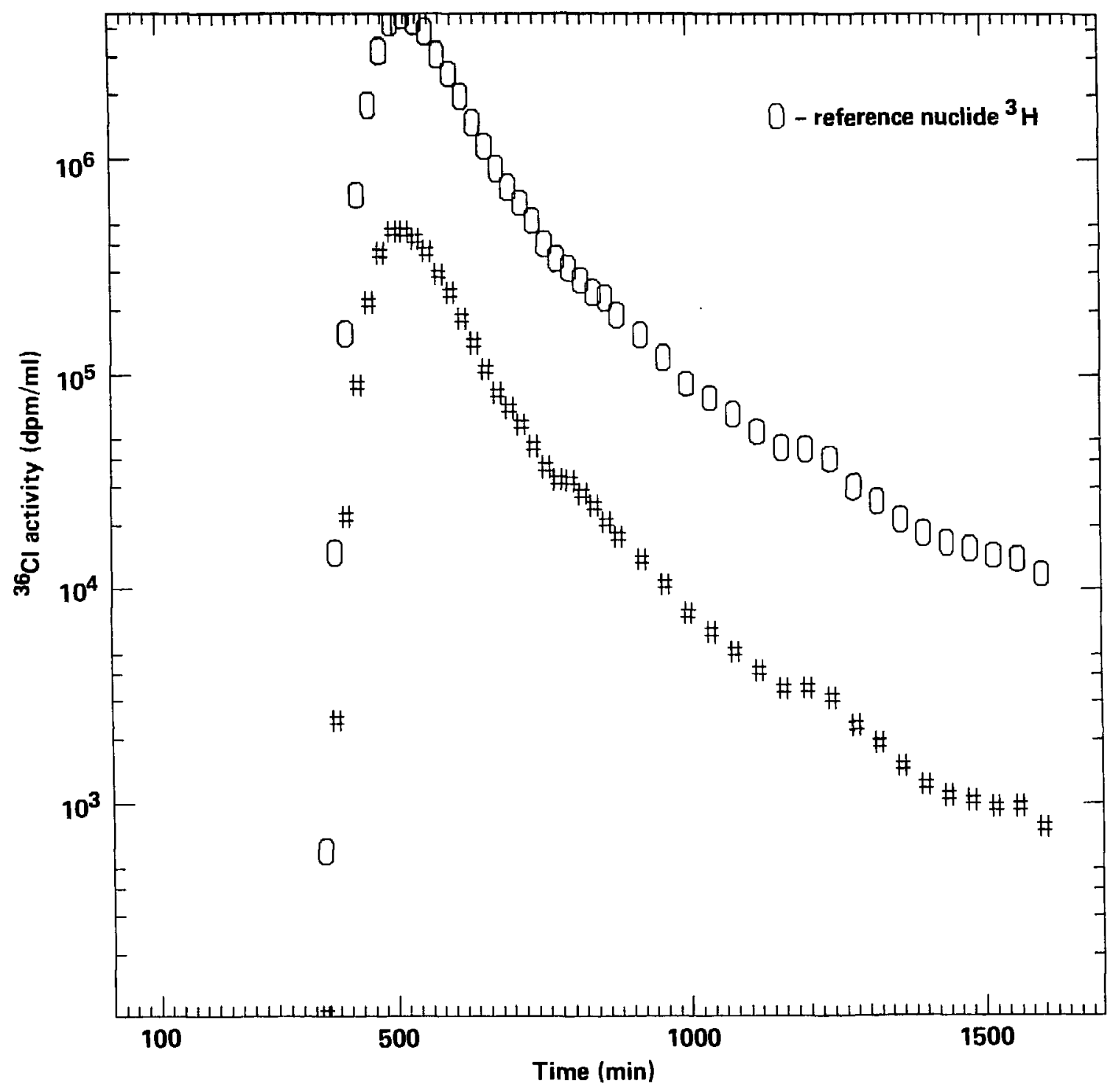

Figure $\mathrm{B4} .{ }^{3 \mathrm{H}}$ and ${ }^{36} \mathrm{Cl}$ overlap plot (a complete output file includes overlap plots of a chosen reference nuclide with the activity of all remaining radionuclides vs time and cumulative volume). 


\section{ORB-User Dialog for Typical Run}

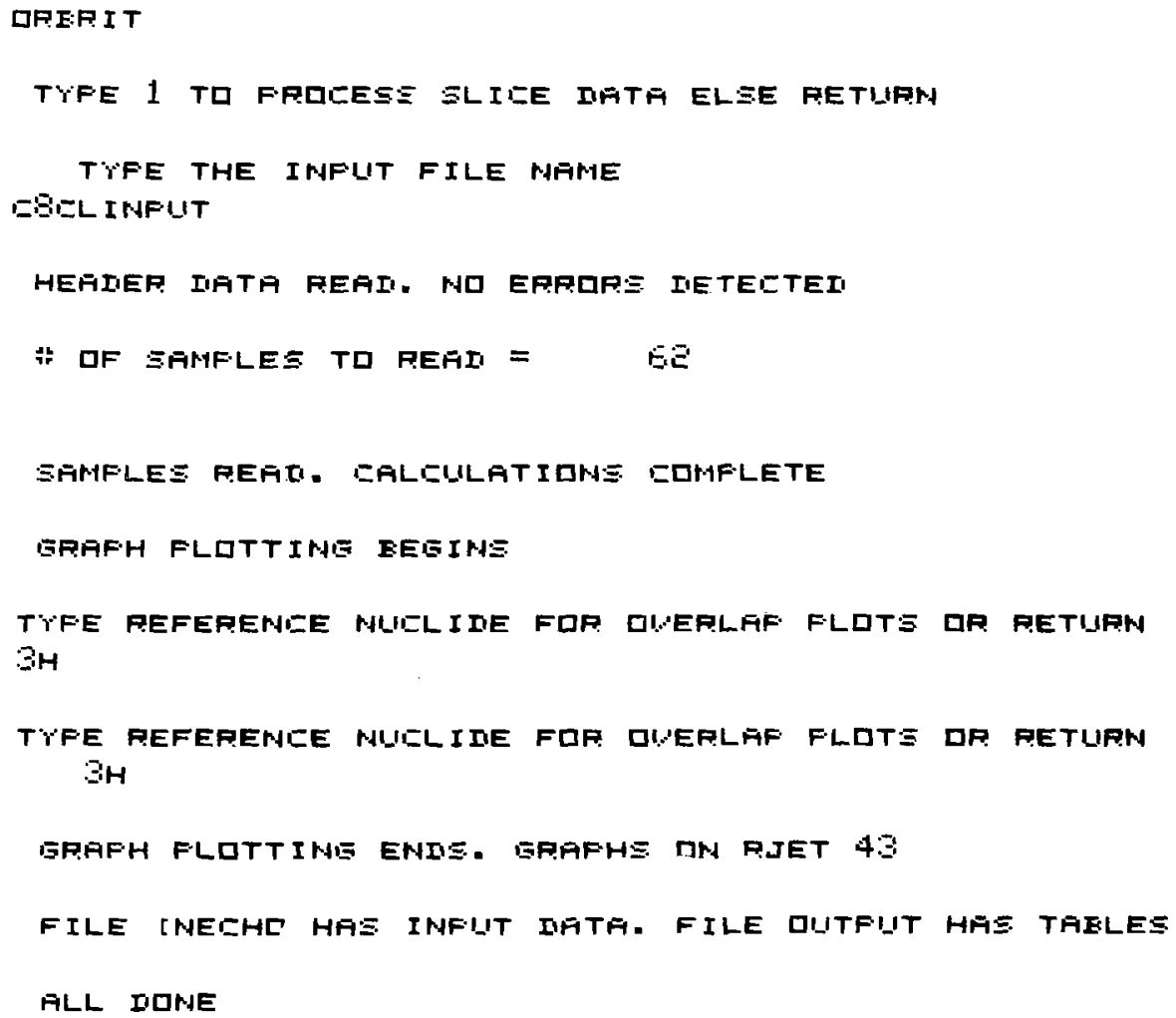




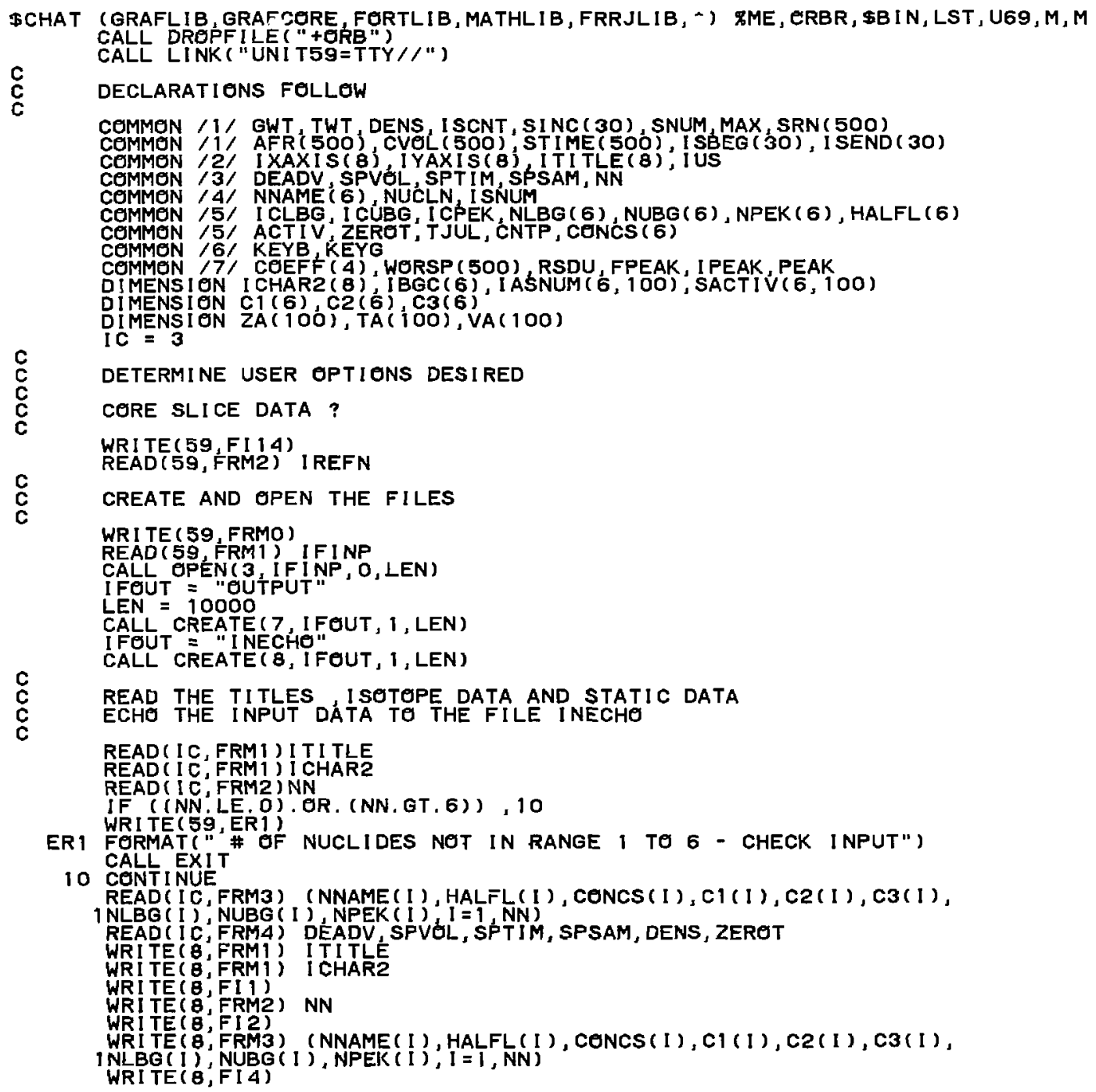


WR I TE ( $\theta$, FRM4) DEADV, SPVOL, SPTIM, SPSAM, DENS, ZEROT

C READ THE INCREMENT DATA

C WRITE(B,FI3)

DO 20 I $=1,30$

READ (IC, FRMS) I SBEG (I ), I SEND( I), S I NC (I)

IF (ISEND(I) EQ. O) GO TO 30

WRI TE (B, FRMS) I SBEG (I), ISEND ( I ), SINC (I)

30 CONT I NUE

$\stackrel{c}{c}$

CHECK FOR INPUT ERRORS

1 IERR $=0$

CALL ERCHK I ( IERR)

IF (I ERR. EQ. I) GO TO OUT

$\stackrel{c}{c}$

FIND \# of SAMPLES AND WRITE STATUS MESSAgE TO USER

NSAMP $=1$ SEND $(M A X)-I \operatorname{SBEG}(1)+1$

WRI TE ( $59, F T 1)$

WRI TE (59, FT2) NSAMP

$c$
$c$
$C$

CALCULATE THE TIMES FROM THE INCREMENT DATA

$T_{T=O M L}=0.0$

De $60 \quad 1=1$, MAX

TINCR = SÍNC(I)

DO $50, J=I$ I SBEG ( I ), I SEND ( I )

TCUML = TCUML + TINCR

$\operatorname{STIME}(1 \mathrm{~J})=$ TCUML

50 CONT I NUE

C

NSAMP $=I \operatorname{SEND}(\operatorname{MAX})-1 \operatorname{SBEG}(1)+1$

WR I TE ( 7, FRMG)

WRI TE (, FIS)

$\mathrm{C}$
$\mathrm{C}$
$\mathrm{C}$

ISCNT $=0$

READ IN EACH SAMPLE. FROM KEYB AND KEYG DECIDE ON HOW MANY OF EACH NUCLIDE TÓ READ (IF ANY).

DO $300 \quad I=1$, NSAMP

READ(IC, FR1O) ISNUM, TWT, GWT, KEYB, KEYG

WRITE $(B, F I 6)$ I INUM, TWT, GWT, KEYB, KEYG

SRN (I) = FLOAT (ISNUM)

C C CHECK FUR ERRORS

IERR = 0

CALL ERRCHK2(IERR, I)

IF (IERR. EQ. I) GO' TO 300

C CALCULATE FLOW RATES AND SET $X$ AXIS PLOT WINDEW

CALL VOLFLO 


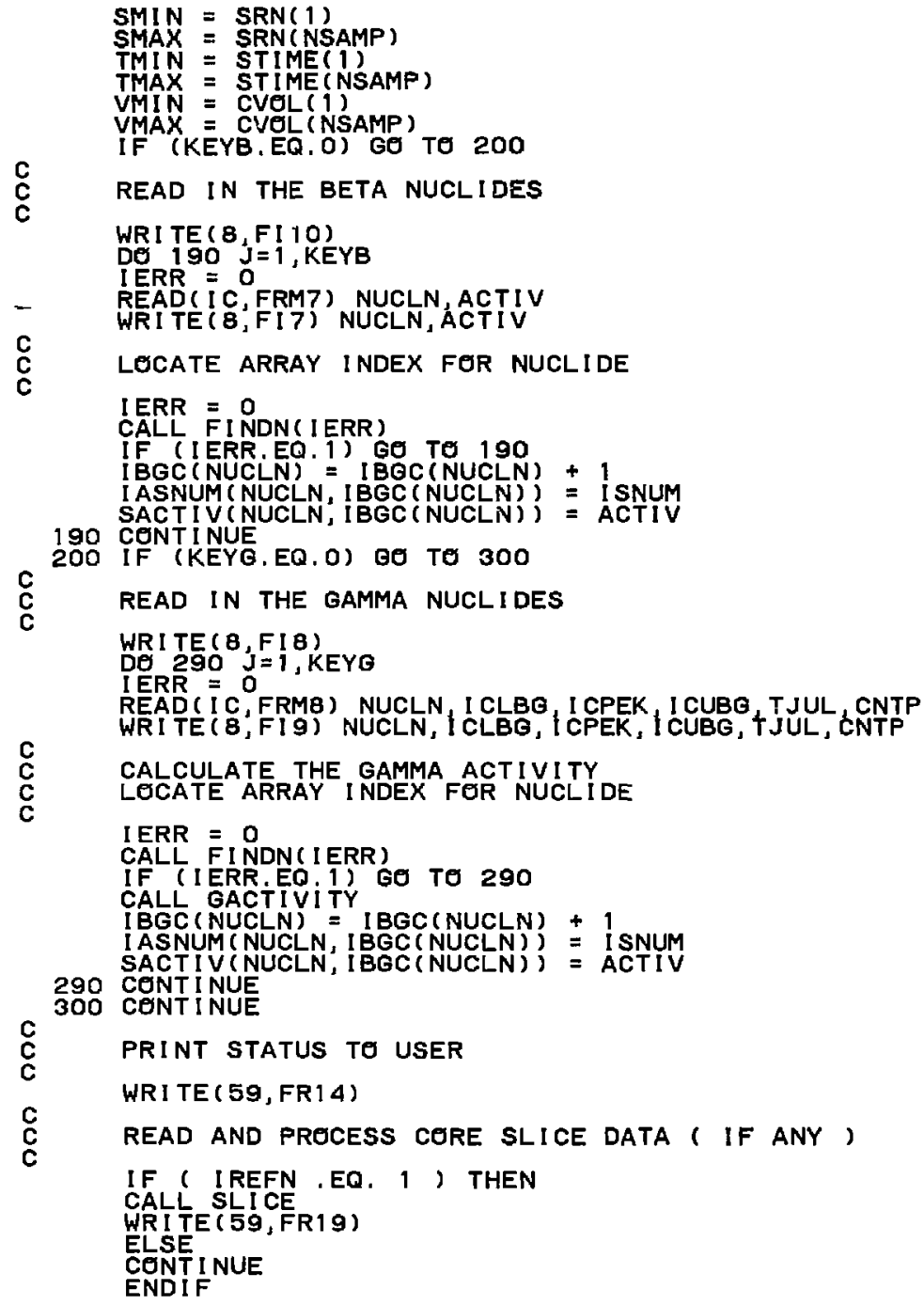




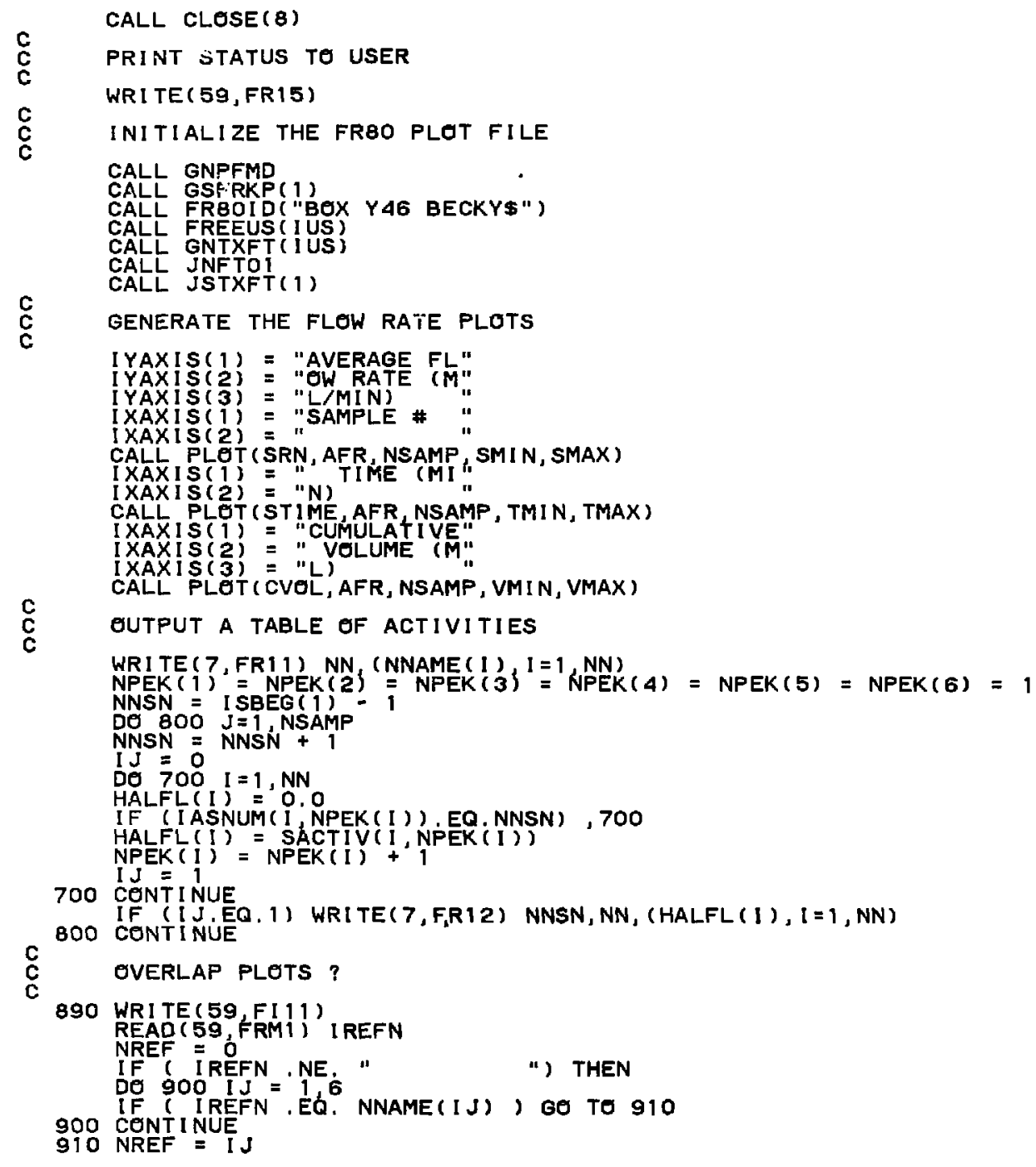




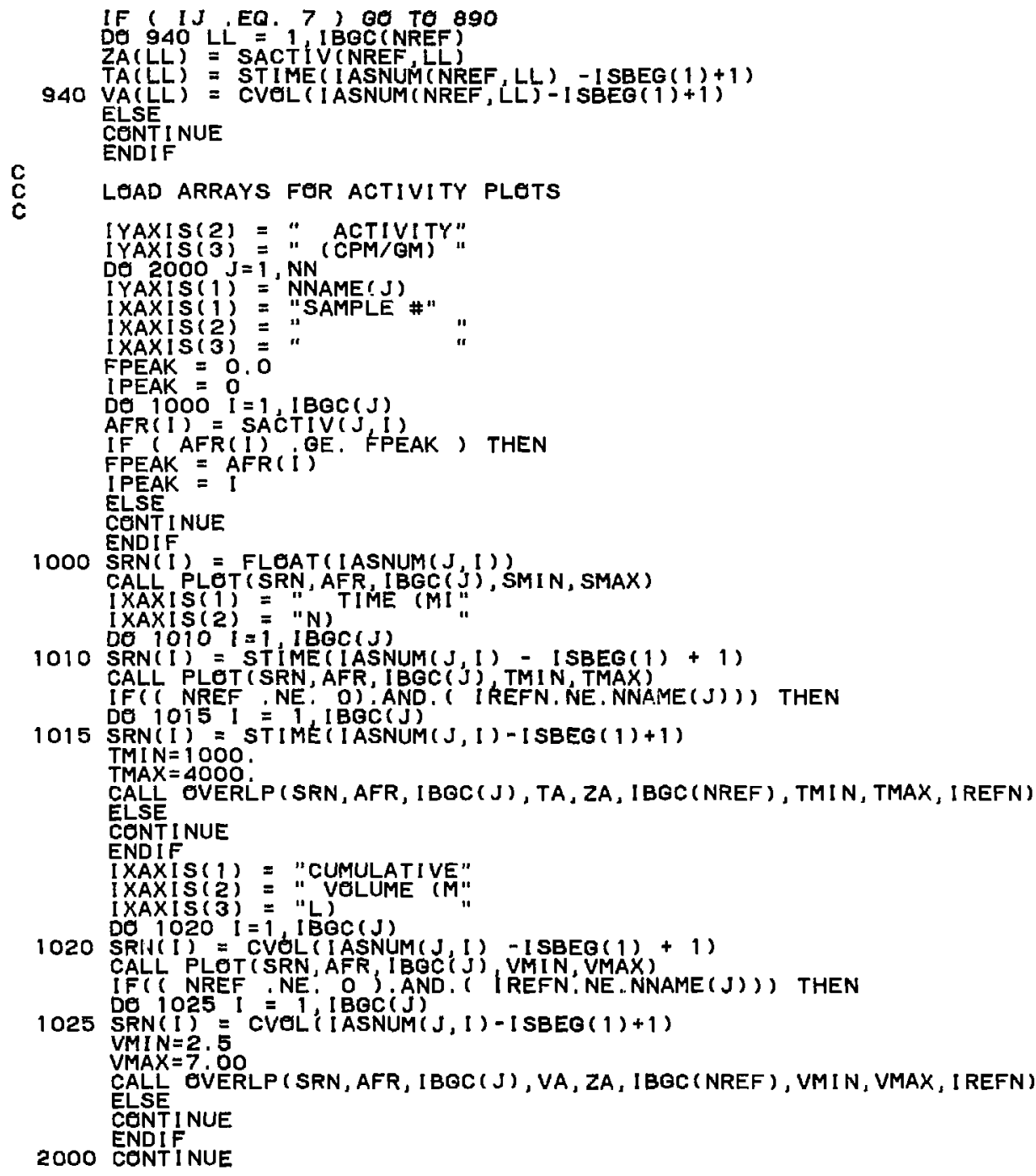




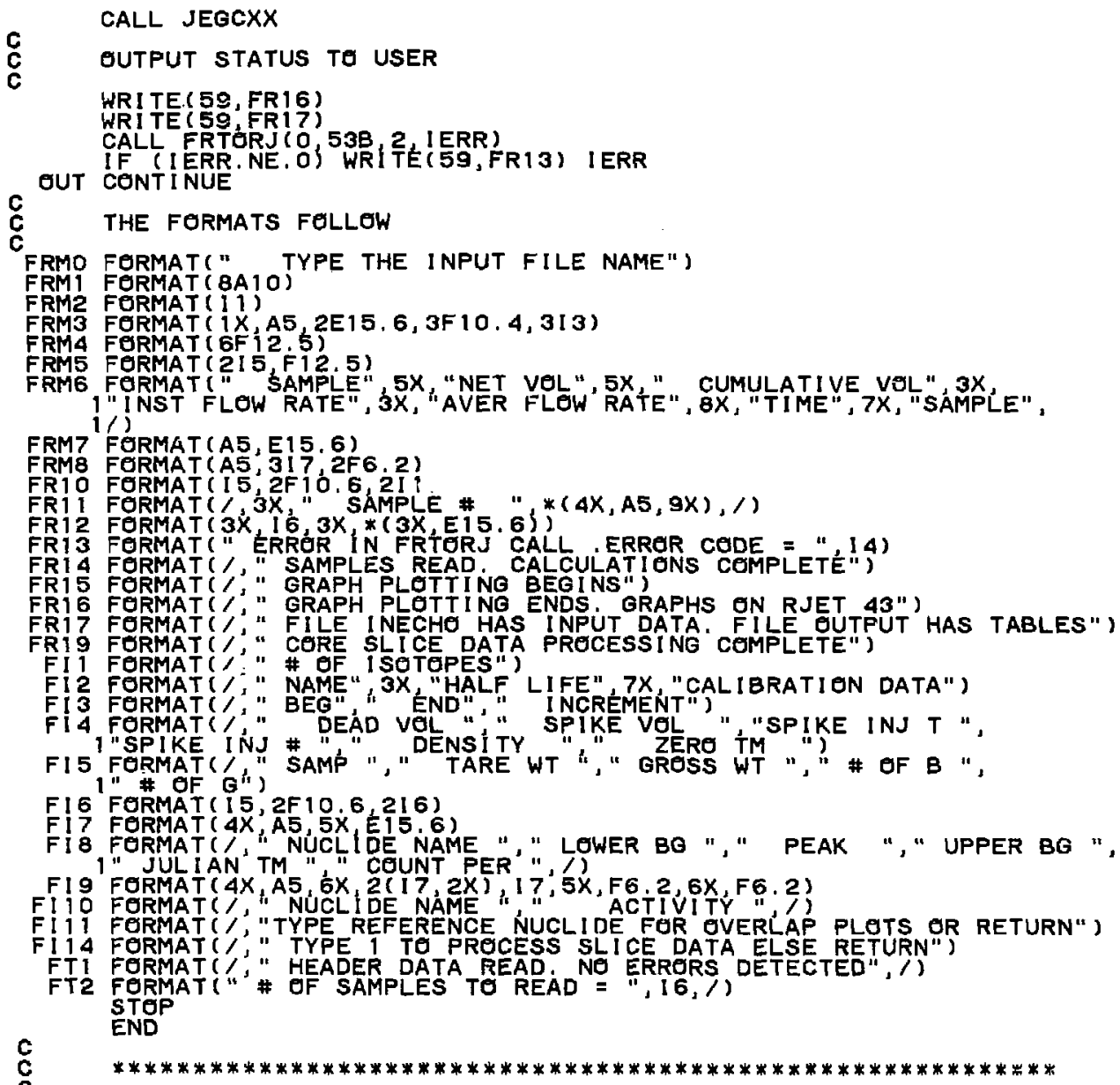

THIS SUBROUTINE CALCULATES VOLUMES AND FLOW RATES. THE RESULTS ARE WRITTEN TO AN OUTPUT FILE.

SUBROUTINE VOLFLO 


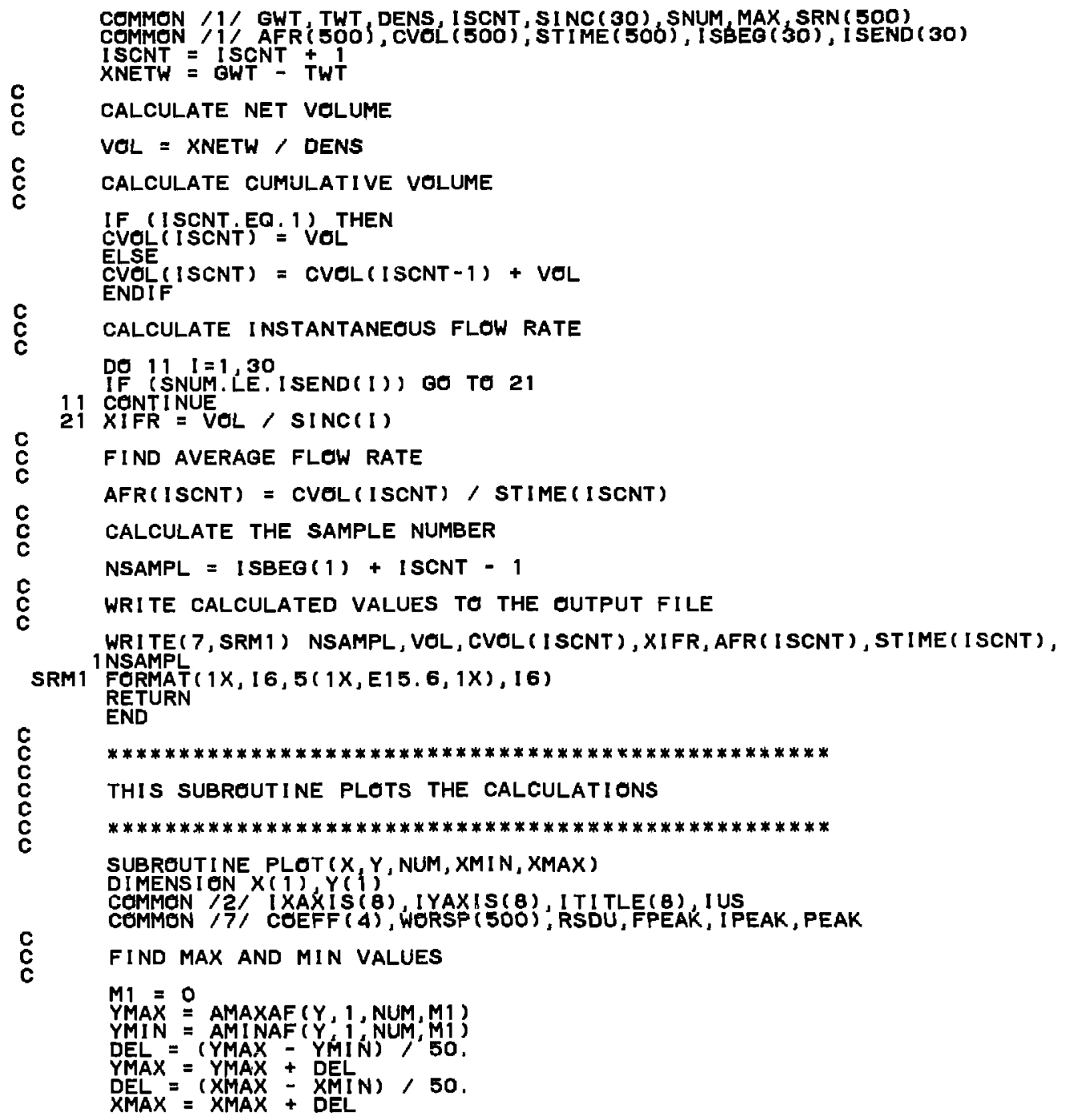




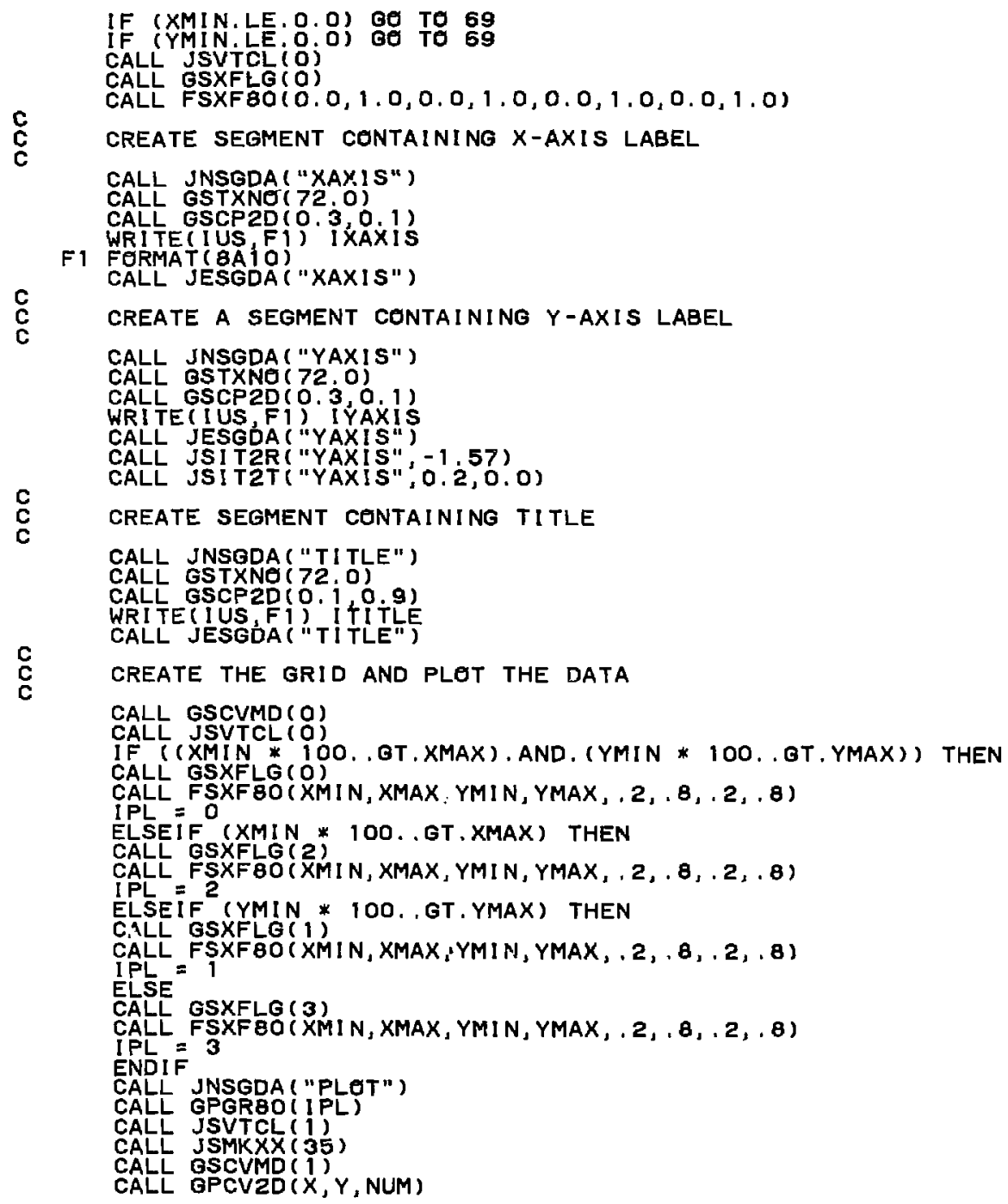




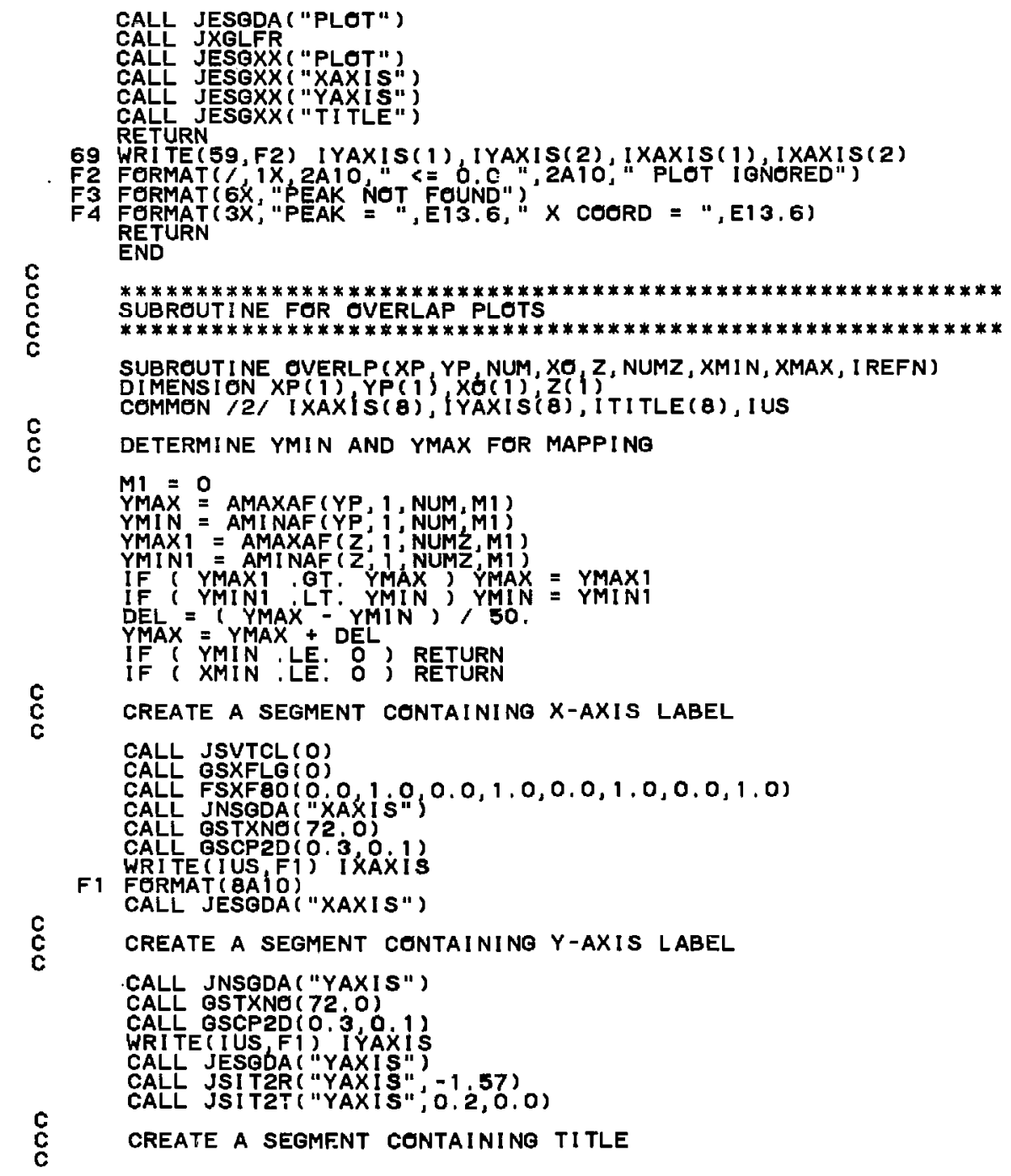




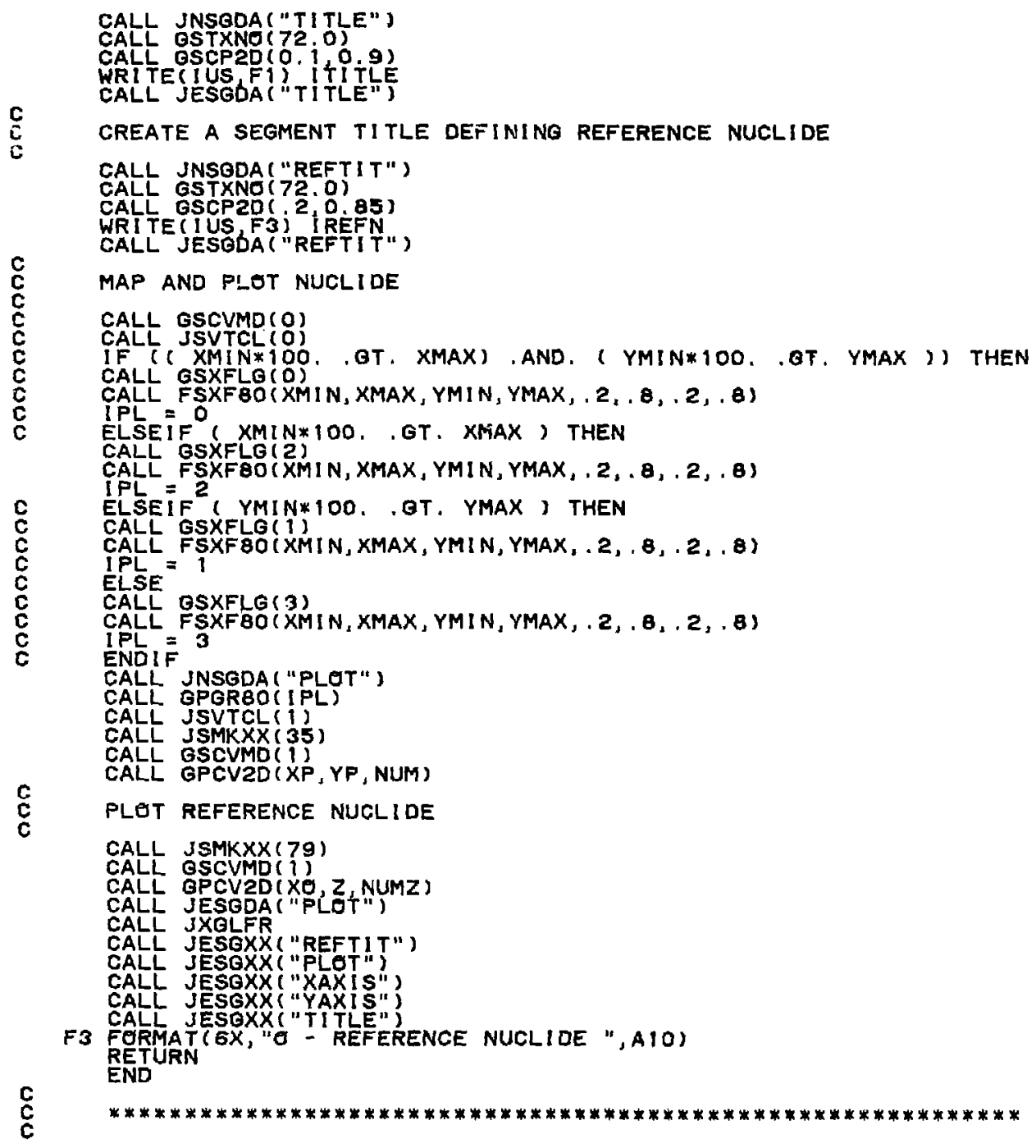



C THIS REUTINE CALCULATES THE ACTIVITY FOR THE GAMMA EMITTING
C

c

SUBROUTINE GACTIVITY

COMMON / I/ GWT, TWT DENS, I SCNT, SINC(30), SNUM, MAX, SRN (5OO)

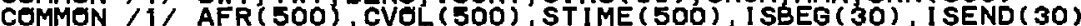

COMMON 15 , ICLBO, I CUBG, I CPEK, NLBo $(6)$, NUBG (6), NPEK (6), HALFL (6)

COMMON /5, ACTIV; ZERUT; TJUL, CNTP, CONCS (6)

$\stackrel{\mathbf{C}}{\mathbf{C}}$

BACKGRUUND CALCULATION

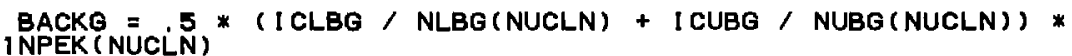

$c$
$\mathrm{C}$
$\mathrm{C}$
$\mathrm{C}$
$\mathrm{c}$
$\mathrm{c}$
$\mathrm{c}$
$\mathrm{c}$
$\mathrm{C}$
$\mathrm{c}$
$\mathrm{c}$
$\mathrm{c}$

COUNTS PER MINUTE

CPM $=($ ICPEK - BACKG $) /$ CNTP

Č WILL INCLUDE CALIBRATION DATA LATER

$\mathrm{DPM}=\mathrm{CPM}$

C CORRECT FUR DECAY

DPM = DPM * EXP( $(.69314718 /$ HALFL (NUCLN)) *(TJUL - ZEROT $))$

C

VOL $=($ GWT - TWT $) /$ DENS

$A C T I V=D P M / V O L$

RETURN

c
C
C
C

SUBROUTINE FINDN FINDS THE ARRAY INDEX FGR THE GIVEN NUCLIDE **********************************************************

SUBROUT INE FINDN (IERR) COMMON , 4 / NNAME (6), NUCLN, I SNUM

Do $10 \quad 1=1,6$

- IF ( NNAME' (i) . EQ. NUCLN, 00 TO 30 WRITE(59, Fi) NUCLN, ISNUM

IERR = 1

F1 FORMAT, " NUCLIDE ", A5, "IN SAMPLE ", I5," NOT VALID-IGNORED")

NUCLN $=1$

RETURN

$c$
$c$
$c$
$c$
$c$
$c$

THIS ROUTINE CHECKS THE RANGES OF THE INPUT DATA UP TO

THE SAMPLE DATA FOR ERRORS, AN ERROR RESULTS IN AN ERROR MESSAOE PRINTED AT THE USERS TERMINAL AND TERMINATIEN. 


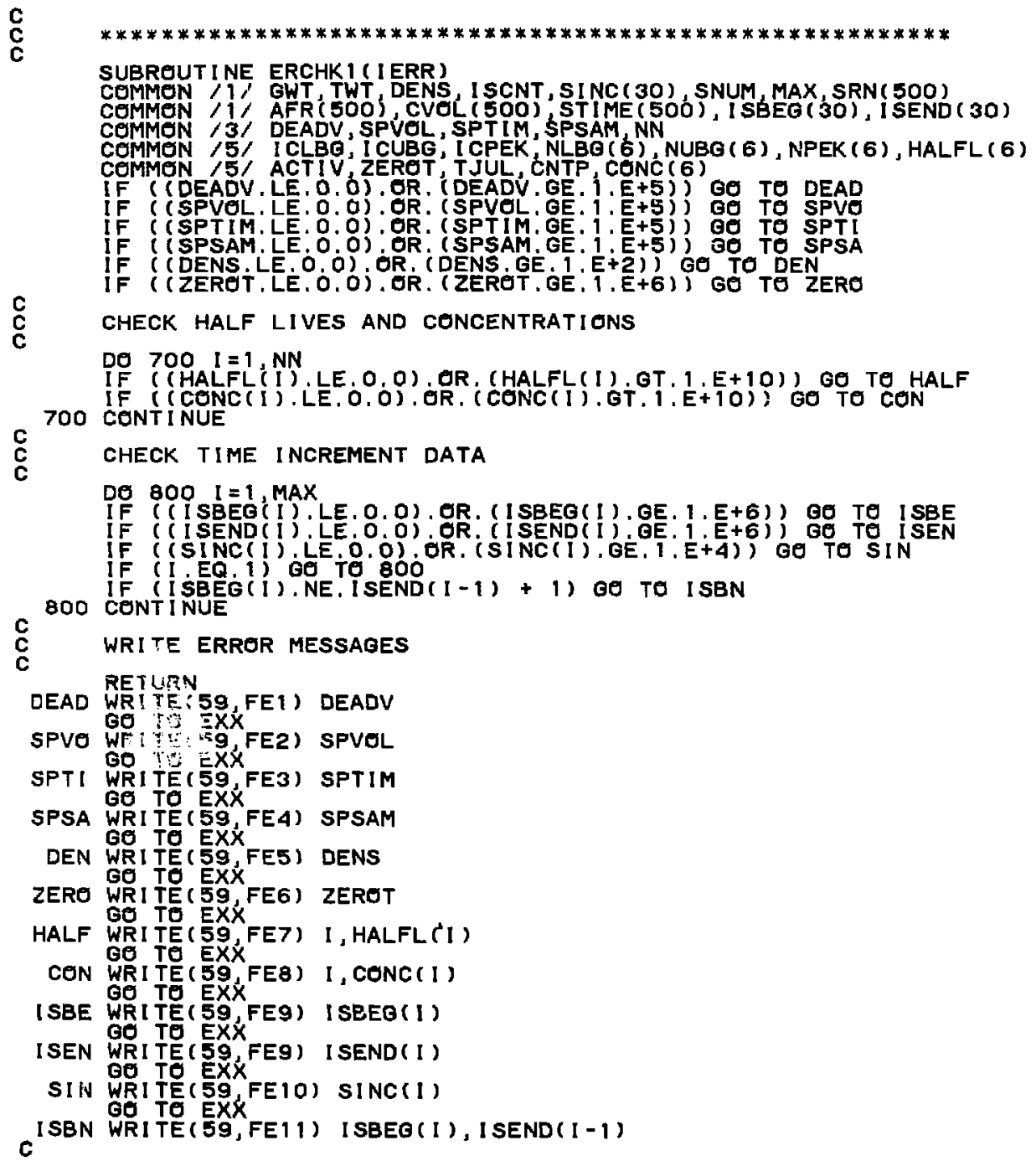


FORMAT (" DEAD VOLUME = "E15,6," I NPUT ERROR" )

FERMAT(" \$PIKE VOLUME " "

FGRMAT(" SPIKE SAMPLE \#" "EI5.6 " INPUT ERROR")

FORMAT (" SOLUTION DENSITY" " E15.6" "INPUT ERROR" )

FERMAT " "ZERO TIME = "E15.6 "I NPU广 ERROR")

FE7 FGRMAT(" HALF L IFE OF NUCL IDE " I " " " " "E15,6, " INPUT ERROR")

FES FORMAT " "SAMPLE NUMB

FE10 FERMAT(" SAMPLE INCREMENT E "E 15.6 " INPUT ERROR" )

E12 FERMAT(" RUN TERMINATED. CERRECT ÉRROR IN INPUT FiLE AND RERUN") WRI TE ( 59, FE 12 )

CALL CLÓSE $(7)$

CALL CLESE ( 8 )

RETURN

END

$\mathrm{C}$
$\mathrm{C}$
$\mathrm{C}$
$\mathrm{c}$
$\mathrm{c}$
$\mathrm{c}$
$\mathrm{c}$
$\mathrm{c}$

THIS ROUTINE CHECKS TIHE SAMPLE WEIGHT AND SAMPLE NUMBER DATA FOR ERRORS.

SUBROUT INE ERRCHK2 ( I ERR, I)

COMMON $11 \%$ GWT, TWT, DENS' I SCNT, SINC (3O), SNUM, MAX, SRN (5OO)

COMMON, 1 , AFR' (5OO), CVEL (5OO) ' STIME (5Ó), I SBEG (30), I SEND ( 30 )

COMMON /3/, DEADV SPVEL, SPTIM, SPSAM, NN

COMMON /6/ KEYB, KEYG

IF ((KEYB.GT.NN). QR. (KEYG.OT.NN)) GO TO KEY

IF (GWT - TWT, LE, O) GO TO WGT

IF (I.GT, 1) THEN

IF (SRN(I) - 1, NE, SRN $(1-1))$ GO TO SRE

ELSE

IF (ISBEG (1). NE. SRN (I)) GO TO BEG

ENDIF

KEY WRITE ( $59, F E 1)$ SRN(I)

GU Tô I Śc

WGT WRI TE( 59, FE2) SRN(I)

GO TO ISC

SRE WRI TE( 59 ,FE3) SRN(I)

GO TO ISC

BEG WRITE (59,FE4) SRN(I)

ISC ISCNT $=$ ISCNT +1

WRITE (59, FES)

IERR ”

FGRMAT(" SAMPLE \# "TARE WT ¿

FORMAT (" FIRST SAMPLE \#, "I " " NOT SAME AS INCREMENT CARD" )

FORMAT (" SAMPLE IGNORED. "PRÚCESSIŃN CONTINUES")

RETURN

$\stackrel{c}{c}$ END 


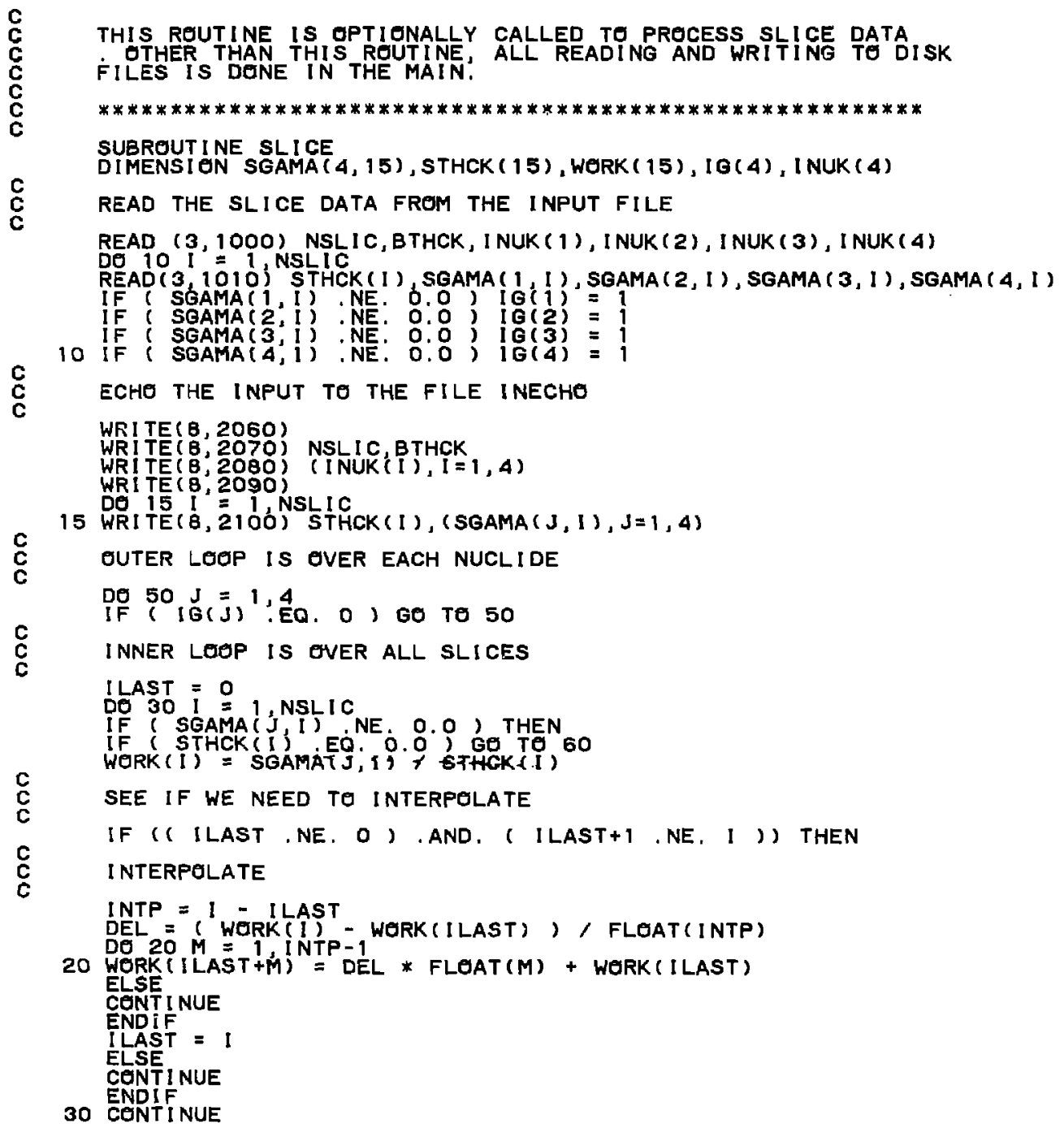




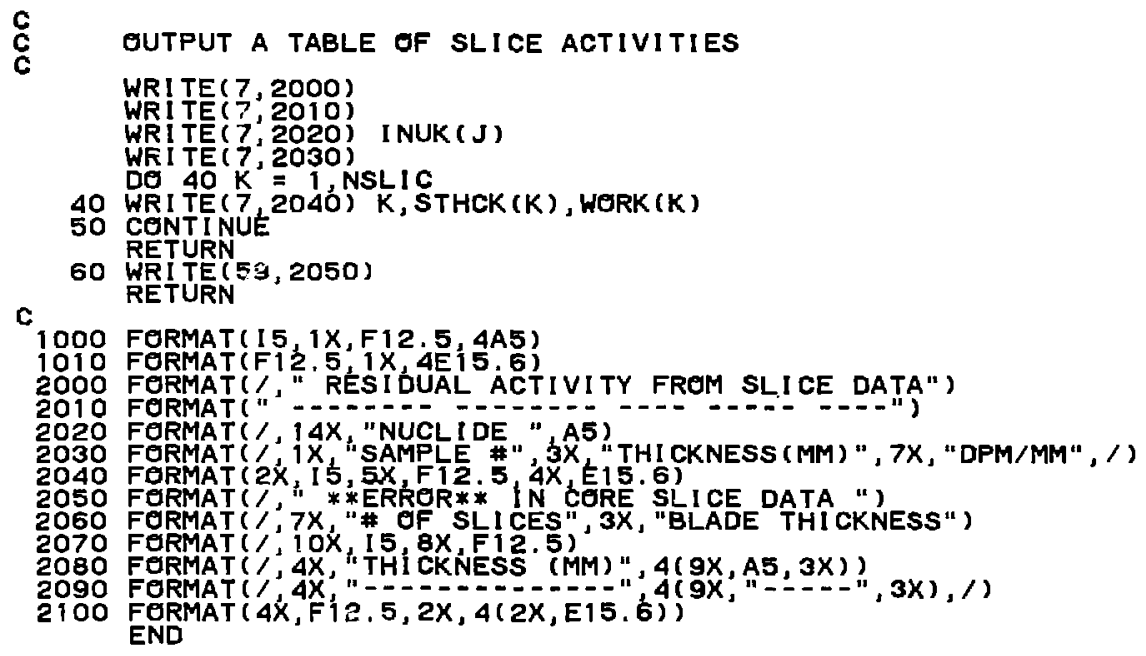


FRACTURED GRANITE CORE 25 SORPTION RUN WITH 3H, 95MTC, 85SR, $137 \mathrm{CS}$ NATURAL FRACTURE, DISTILLED WATER, NO TEFLON G-RINGS NEW INLET FITTING

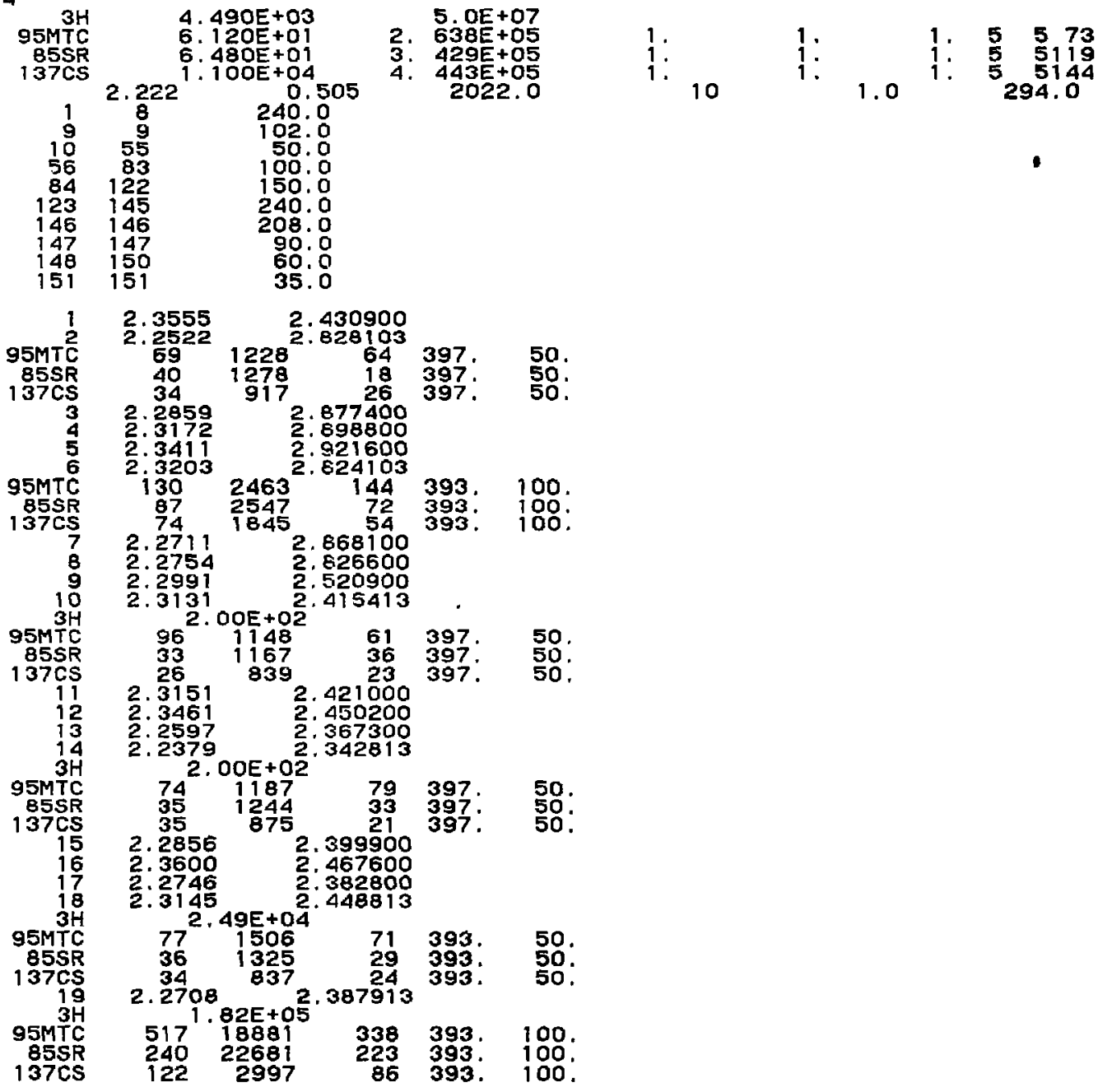

$\begin{array}{ll}2.2859 & 2.877400 \\ 2.3172 & 2.898800\end{array}$

397. 50.

397. 50.

2. 3411

2. 824103

95MTC $130 \quad 2463^{2.824144} 393.100$

$\begin{array}{llllll}85 S R & 67 & 2547 & 72 & 393 . & 100 . \\ 137 \mathrm{CS} & 74 & 1845 & 54 & 393 . & 100 .\end{array}$

$\begin{array}{rr}2.2711 & 2.868100 \\ 2.2754 & 2.826600\end{array}$

2. 5260

2.3131

2.520900

3131 . OOE +02

36
33 11467

26

2. 3151

839

2. 2597

2. 421000

61397

$85 S R$
$137 \mathrm{CS}$

1

13

$3 \mathrm{H}$

2. 2379

2. 450200

$397^{\circ} \quad 50$.

$95 M T C$

$137 \mathrm{Cs}$

\begin{tabular}{rrrrr}
$74^{2.00 E+02}$ & 1187 & 79 & 397. & 50 \\
35 & 1244 & 33 & 397. & 50 \\
35 & 875 & 21 & 397. & 50. \\
2.2856 & \multicolumn{2}{c}{2.399900} & &
\end{tabular}

$\begin{array}{ll}2.3600 & 2.467600 \\ 2.2746 & 2.382800\end{array}$

2. 3145 2. 448813

$3 \mathrm{H}$

95MTC

85SR

19

$95 M T C$

$2.49 E+04.448813$

$\begin{array}{rrrrr}77^{2} .495+04 & 1506 & 71 & 393 . & 50 \\ 36 & 1325 & 29 & 393 . & 50 \\ 34 & 837 & 24 & 393 . & 50 . \\ 2.2708 & & 2.387913 & & \end{array}$

2.2708 . $22 E+05.387913$

$137 \mathrm{Cs}$

$\begin{array}{rrrrr}517^{1} \cdot 82 E+05 & 18881 & 338 & 393 . & 100 . \\ 240 & 22681 & 223 & 393 . & 100 . \\ 122 & 2997 & 86 & 393 . & 100 .\end{array}$

Continues for all samples 


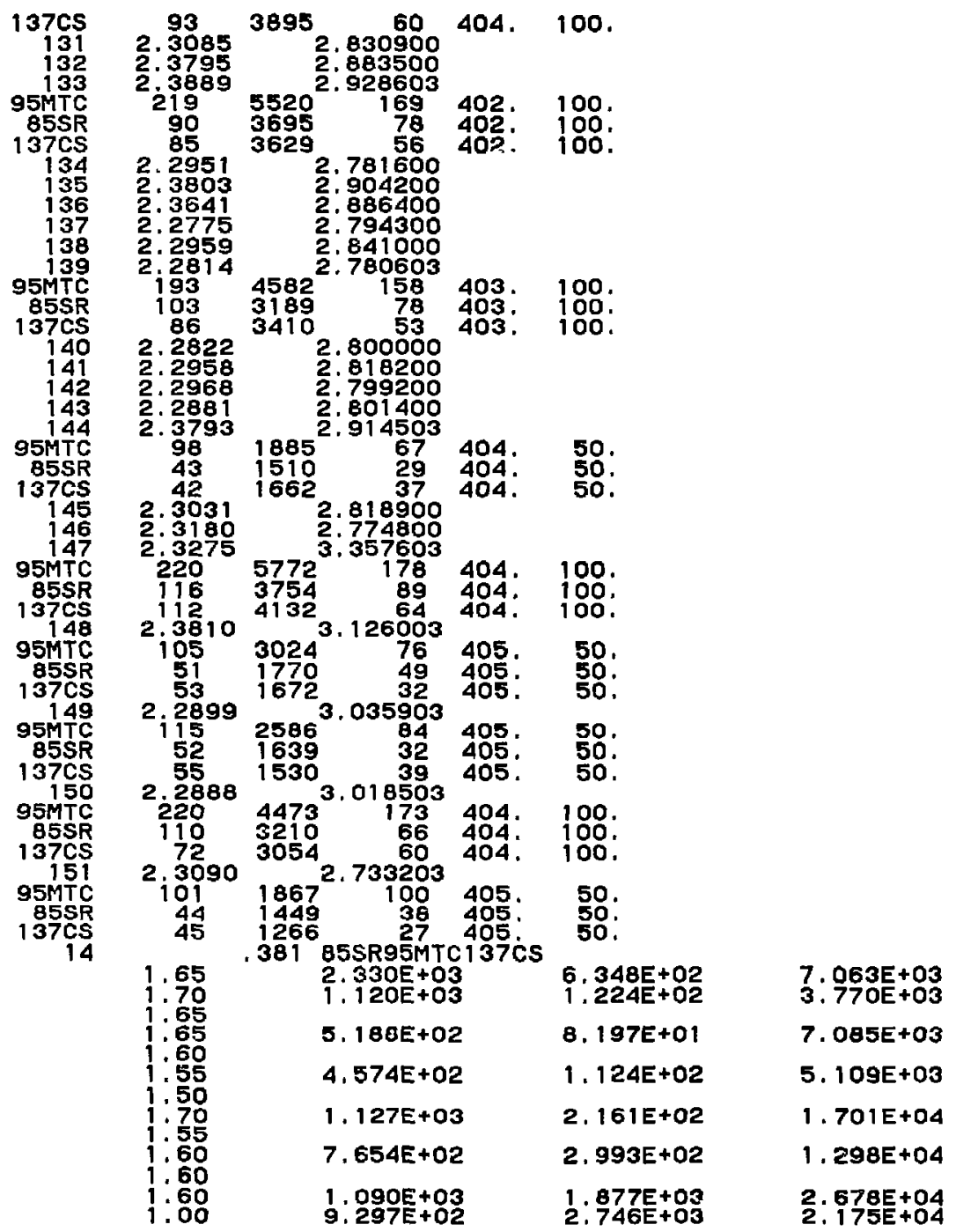




\section{Sample INECBO File from ORB Program}

FRACTURED GRANITE CORE 25 SORPTION RUN WITH 3H, 95MTC 85SR $137 \mathrm{CS}$ NATURAL FRACTURE, DISTILLED WATER, NO TEFLON O-RINGS NEW INLET FITTINO \# OF I SOTOPES

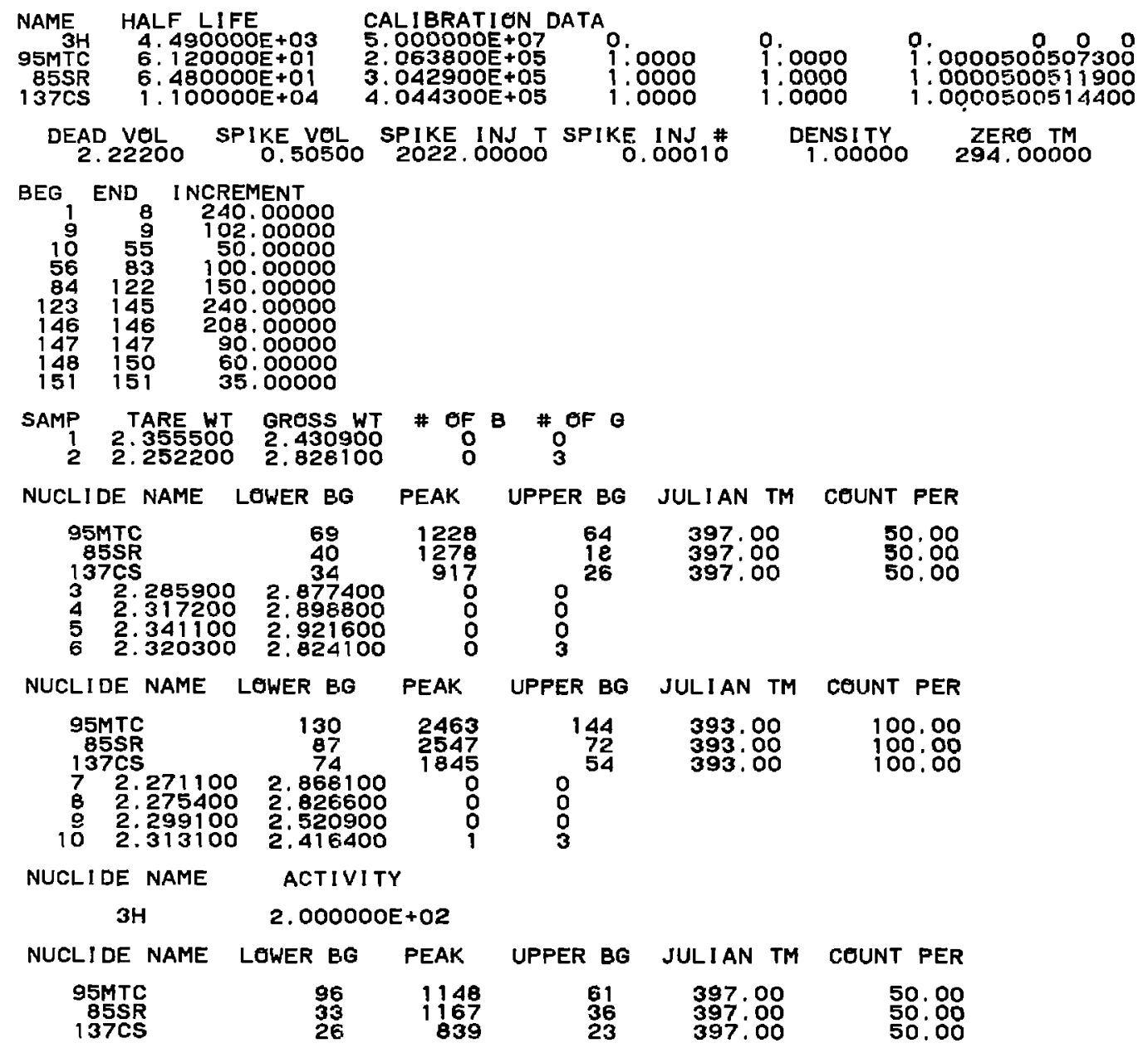

Continues for all samples 
NUCLIDE NAME LOWER BG PEAK UPPER BG JULIAN TM COUNT PER

\begin{tabular}{|c|c|c|c|c|}
\hline $\begin{array}{c}\text { 95MTC } \\
85 S R \\
137 C S \\
150^{2} 2.288800\end{array}$ & $\begin{array}{c}115 \\
52 \\
55 \\
3.016500\end{array}$ & $\begin{array}{l}2586 \\
1639 \\
1530 \\
\end{array}$ & $\begin{array}{r}84 \\
32 \\
39 \\
3^{39}\end{array}$ & $\begin{array}{l}405.00 \\
405.00 \\
405.00\end{array}$ \\
\hline
\end{tabular}
NUCLIDE NAME LOWER BG PEAK UPPER BG JULIAN TM COUNT PER

\begin{tabular}{|c|c|c|c|c|}
\hline $\begin{array}{c}\text { 95MTC } \\
\text { 85SR } \\
15137 \text { CS } \\
151309000\end{array}$ & $\begin{array}{c}220 \\
110 \\
772 \\
2.733200\end{array}$ & $\begin{array}{r}4473 \\
3210 \\
3054 \\
0\end{array}$ & $\begin{array}{r}173 \\
66 \\
60\end{array}$ & $\begin{array}{l}404.00 \\
404.00 \\
404.00\end{array}$ \\
\hline
\end{tabular}
NUCLIDE NAME LOWER Bg PEAK UPPER Bg JULIAN TM COUNT PER

$\begin{array}{lrrrrr}\text { 95MTC } & 101 & 1867 & 100 & 405.00 & 50.00 \\ \text { 85SR } & 44 & 1449 & 38 & 405.00 & 50.00 \\ 137 C S & 45 & 1266 & 27 & 405.00 & 50.00\end{array}$

\# ef slices blade thickness

$14 \quad 0.38100$

THICKNESS (MM)

85SR

95MTC

$137 \mathrm{CS}$

\begin{tabular}{|c|c|}
\hline $\begin{array}{l}1.65000 \\
1.70000 \\
1.65000 \\
1.65000 \\
1.60000 \\
1.55000 \\
1.50000 \\
1.70000 \\
1.550000 \\
1.60000 \\
1.600000 \\
1.000000 \\
1.40000\end{array}$ & 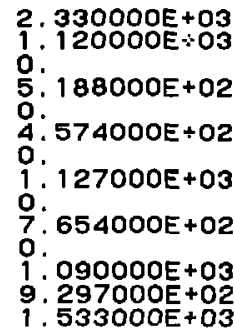 \\
\hline
\end{tabular}

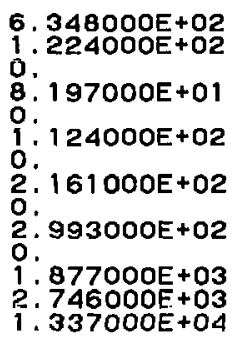

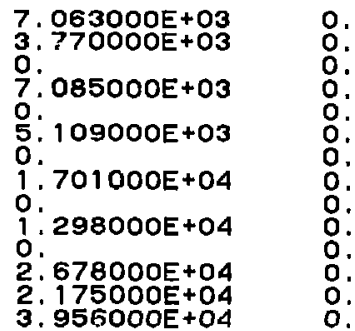


SAMPLE NET VEL

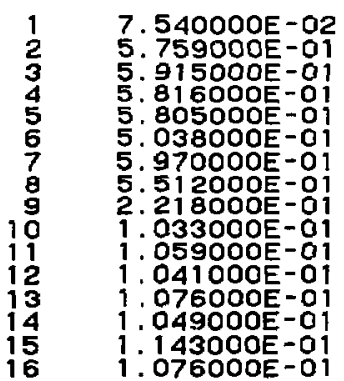

CUMULATIVE VOL

$7.540000 E-02$

6. $513000 \mathrm{E}-01$

1. $242800 E+00$

2. $404900 \mathrm{E}+00$

. $908700 E+00$

3. $505700 \mathrm{E}+00$

4. 256900 +OO

4. $382000 \mathrm{E}+00$

4. $487900+00$

4. $92000+00$

4.690

4. $918800 E+00$
5. $026400 E+00$
INST FLOW RATE

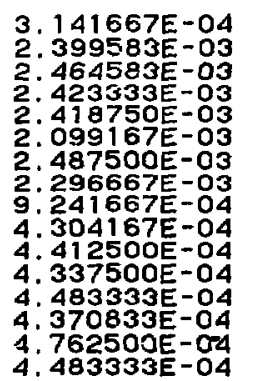

AVER FLOW RATE

$3.141667 \mathrm{E}-04$
$1,356875 \mathrm{E}-03$

.726111 - 03

2. $004083 E-03$

2. $019931 \mathrm{E}-03$

2. $1126726 \mathrm{E}-03$

2. $116073 \mathrm{E}-03$

2. $114865 E-03$

2. $114180 E-03$

2. $115032 E-03$

2. $118346 \mathrm{E}-03$
TIME

2. $400000 \mathrm{O}+02$

$7.200000 E+02$

, $600000 E+02$

. 200000E+03

440000E+03

$1.680000 \mathrm{E}+\mathrm{n3}$

1.920000+o3

2. $072000 \mathrm{E}+03$

. $122000 E+03$

(22000 +03

$2.22200 \mathrm{O}+03$

$2,372000 E+03$
SAMPLE

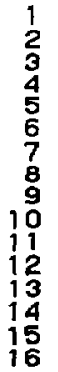

Continues for all sample 


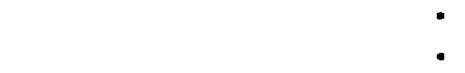

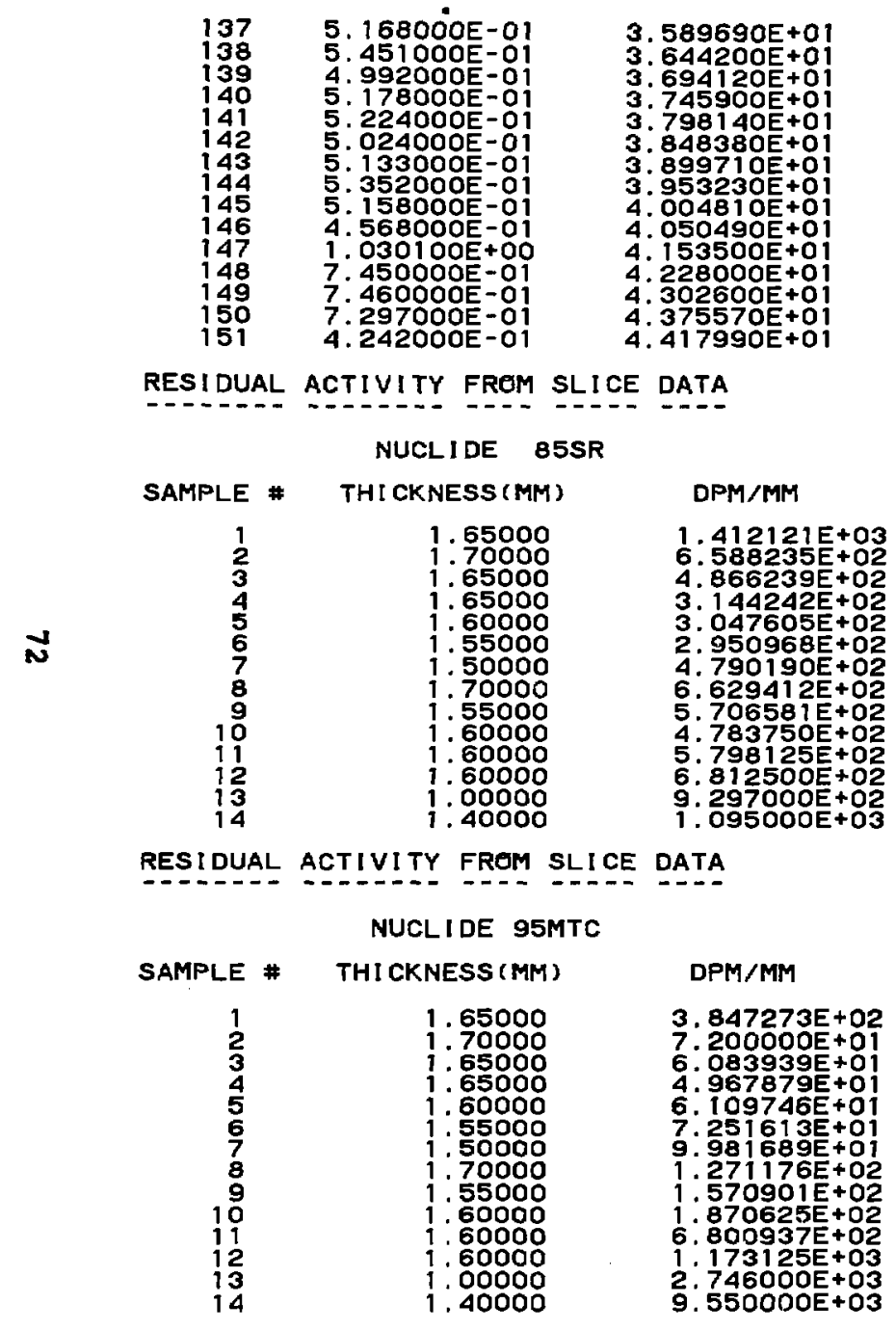

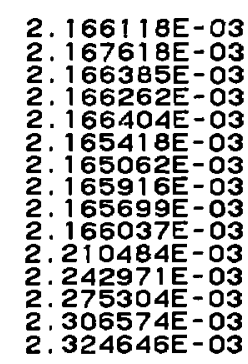

1. $657200 E+04$

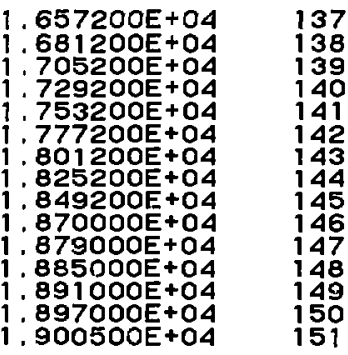

NUCLIDE 85SR

\section{$1.412121 E+03$}

.866239E+02

$047605 \mathrm{E}+02$

$.950968 \mathrm{E}+02$

.79019

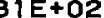

$1: 095000 \mathrm{E}+03$

RESIDUAL ACTIVITY FROM SLICE DATA

\section{NUCLIDE 95MTC}

3. $847273 E+02$
$7.200000++01$
$6.083939 E+01$
$4.967879 E+01$
$6.109746 E+01$
$7.251613 E+01$
$9.981689+01$
$1.271176 E+02$
$1.570901 E+02$
$1.870625 E+02$
$6.800937+02$
$1.173125 E+03$
$2.746000+03$
$9.550000+03$ 
RESIDUAL ACTIVITY FREM SLICE DATA

NUCL I DE $137 \mathrm{CS}$

SAMPLE \# THICKNESS (MM)

1
2
3
4
5
5
7
6
9
10
11
12
13
14

SAMPLE \#

2
6
10
14
18
19
20
21
22
23
24
25
26
27
28
29
30
32
34
38
41
44
46
49
53
60
65
70
75
82
85
91
96
101
103
104
10
1.65000
1.70000
1.65000
1.65000
1.60000
1.55000
1.50000
1.70000
1.55000
1.60000
1.60000
1.60000
1.00000
1.40000

3H o.

o.

0 .

0 .

o.

0 .

O.

o:

:

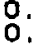

$0:$

:

o.

o.

o:
DPM/MM

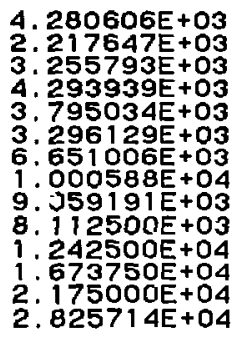

95MTC

1. $369357 \mathrm{E}+02$

2. $000000 \mathrm{O}+02$

2. OQOOOOE +02

2. $490000 \mathrm{E}+04$

1. $820000 \mathrm{E}+05$

3. $910000 \mathrm{E}+05$

6. $370000 E+05$

B. $970000 E+05$

$1.130000 E+06$

8. $520000 \mathrm{E}+05$

8. $420000 E+05$

4: $790000 E+05$

2. $400000 E+05$

1. $320000 \mathrm{E}+05$
1. $500260 \mathrm{OE}+02$

7. $136857 \mathrm{E}+02$ $7.266758 \varepsilon+02$ $6.882389 \mathrm{E}+02$ $4.908676 \mathrm{E}+03$ 1. $446586 \mathrm{E}+04$ 2. $454442 E+04$ 3. $127546 \mathrm{E}+04$ $3.510513 E+04$ 3. $446242 E+04$ 3. $150392 E+04$ 2. $775642 \mathrm{E}+04$ 2. $351620 E+04$ 1. $876308 \mathrm{E}+04$ $1.541388 \mathrm{E}+04$ 1. $198021 \mathrm{E}+04$ 9. $980355 \mathrm{E}+03$ $6.519416 \mathrm{E}+03$ 3. $476619 \mathrm{E}+03$ 2. $513782 E+03$ 2. $196134 \mathrm{E}+03$ $1.901443 E+03$ $1.680314 \mathrm{E}+03$ $1.515365 \mathrm{E}+03$ $9.840467 E+02$ $7.682730 \mathrm{E}+02$ 7. $457438 \mathrm{E}+02$ $7.273983 E+02$ 5. $747438 \mathrm{E}+02$ $4.645287 \mathrm{E}+02$ 4. $522289 \mathrm{E}+02$ 4. $064931 \mathrm{E}+02$ 3. $688880 \mathrm{E}+02$ $3.744791 \mathrm{E}+02$ 3. $678087 \mathrm{E}+02$
B5SR

1. $335681 \mathrm{E}+02$ 1. $457732 E+02$ $6.799697 \mathrm{E}+02$ 7. $137793 E+02$ $5.689535 \mathrm{E}+02$ $5.584859 E+03$ 1. $954031 \mathrm{E}+04$ 3. $298308 E+04$ 4. $309294 E+04$ 4. $783570 \mathrm{E}+04$ 4. $192768 E+04$ 3. $791032 E+04$ 3. $143509 E+04$ 2. $557797 \mathrm{E}+04$ 2.007272E+04 $1.580336 \mathrm{E}+04$ 1. $191776 \mathrm{E}+04$ $9.683769 E+03$ 5. $980589 \mathrm{E}+03$ 3. $019206 \mathrm{E}+03$ 2. $174333 \mathrm{E}+03$ 1. $711840 \mathrm{E}+03$ $1.559071 \mathrm{E}+03$ $1.416663 \mathrm{E}+03$ 1. $244711 \mathrm{E}+03$ $8.726504 E+02$ 6. $940859 E+02$ $7.615334 \mathrm{AE}+\mathrm{OL}$ 7. $03385 \mathrm{CE}+02$ 5. $60226 \mathrm{UE}+02$ 4. 306595E+02 4. $646938 E+02$ $4.045286 E+02$ 3. $336198 E+02$ 3. $318834 \mathrm{E}+02$ 3. $285653 \mathrm{E}+02$

\section{$137 \mathrm{Cs}$}

3. $205317 \mathrm{E}+01$ 3. $685085 \mathrm{E}+0$ 1. $634972 \mathrm{E}+02$ $1.679118 \mathrm{E}+02$ $1.254263 \mathrm{E}+02$ 2. $575367 \mathrm{E}+02$ 5. $950425 E+02$ 9. $493502 E+02$ 1. $768063 \mathrm{E}+03$ 3. $520141 \mathrm{E}+03$ $5.843174 E+03$ 7. $025002 E+03$ 6. $082727 \mathrm{E}+03$ $5.044757 \mathrm{E}+03$ 3.914485E+03 3. $104265 E+03$ 2. $385391 \mathrm{E}+03$ 2. $004192 \mathrm{E}+03$ $1.380908 E+03$ $7.827618 \mathrm{BE}+02$ $5.764207 E+02$ $4.809714 \mathrm{E}+02$ $4.343187 E+02$ 3. $799519 \mathrm{E}+02$ $3.512695 \mathrm{E}+02$ $2.261622 \mathrm{E}+02$ $1.909417 E+02$ 1. $930953 \mathrm{E}+02$ 1. $870049 \mathrm{E}+02$ $1.493988 \mathrm{E}+02$ $1.240282 E+02$ 1. $266056 \mathrm{E}+02$ 1. $177319 \mathrm{E}+02$

1. $11768 B \mathrm{BE}+02$ 1. $060070 \mathrm{E}+02$ 1 . $110860 \mathrm{E}+02$

Continues for all $Y$ or $\beta^{-}$analyzed samples 


\section{DISCI.AIMIER}

This document was prepared as an account of work sponsored hy an agency of the I nited Staten (iovernment. veither the I nited States Government nor the I niversity of California nor any of their employees, makes any warranty, express or implied, or assumes any legal liability or responsibility for the accuracy, completeness, or usefulness of any information, apparatus. product, or process disclosed, or represents that it: use would not infringe privately ow ned rights. Keference herein to any specific commercial products, process. or service by trade name, trademark. manufacturer, or otherwise. does not necessarily constitute or imply its endorsement, recommendation. or favoring by the I nifed States Ciovernment or the I niversity of California. The views and opinions of authors expressed herein do nol necessarily state or reflect those of the I nited States Covernment thereof, and shall not he used for advertising or product endorsement purposes. 
Technical Information Department . Lawrence Livermore National Laboratory University of California - Livermore, California 94550

\section{First Class Mail}

